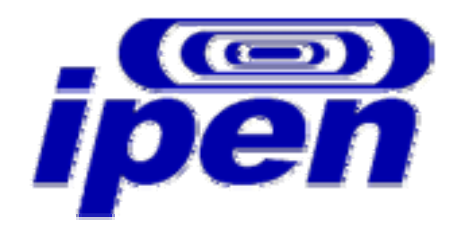

INSTITUTO DE PESQUISAS ENERGÉTICAS E NUCLEARES AUTARQUIA ASSOCIADA À UNIVERSIDADE DE SÃO PAULO

\title{
AVALIAÇÃO POR RPE DE COMPONENTES COM POTENCIAL ANTIOXIDANTE DE VARIEDADES DE SOJA IRRADIADAS COM ${ }^{60} \mathrm{CO}$
}

MARCOS RONALDO RAMOS DE OLIVEIRA

Tese apresentada como parte dos requisitos para obtenção do Grau de Doutor em Ciências na Área de Tecnologia Nuclear - Aplicações.

Orientadora:

Dra. Nélida Lúcia Del Mastro

SÃO PAULO

2009 


\section{DEDICATÓRIA}

Dedico este trabalho à minha Família. À Minha mãe, Helena, e ao meu pai, Juraci, por tudo que sou. Aos meus irmãos, Márcio, Simone e Marcelo, pela companhia. À Mônica, por seu incentivo e amor às causas perdidas. Ao meu filho Murilo, por existir e iluminar a minha vida. Sem a compreensão de todos e paciência este trabalho não seria possível. 


\section{AGRADECIMENTOS}

\section{Agradeço,}

À Doutora Nélida Lúcia Del Mastro, por sua visão de longo alcance e seu otimismo nos momentos de fraqueza ou dúvida de minha parte. Serei sempre grato por sua dedicação e paciência.

Ao Laboratório de Biofísica da USP, pela acolhida e suporte, em particular ao Tiago, pelas dicas no uso do equipamento.

Ao pessoal do CTR-IPEN, em especial à dupla Beth/Carlos pela ajuda com a irradiação das amostras, e à Célia pela dosimetria. Ao Marco e à Cláudia por todo o suporte da Secretaria.

À EMBRAPA, que através do Marcos Mandarino sempre disponibilizou as amostras e toda gama de informações que eu Ihe pedia.

Ao laboratório de alimentos da Farmácia-USP, pelas medidas dos teores de isoflavonas por intermédio da Profa. Maria Inês Genovese.

Ao CNPq, pelo auxílio financeiro durante parte do período em que foram feitas as medidas. 


\title{
AVALIAÇÃO POR RPE DE COMPONENTES COM POTENCIAL ANTIOXIDANTE DE VARIEDADES DE SOJA IRRADIADAS COM ${ }^{60} \mathrm{Co}$
}

\author{
Marcos Ronaldo Ramos de Oliveira
}

\author{
RESUMO
}

Com uma área plantada de cerca de 21 milhões de hectares, e uma produção anual de 60 milhões de toneladas em 2008, o Brasil é hoje o segundo maior produtor de soja no mundo, com pouco mais de um quarto da produção mundial. A presença de flavonóides, em particular isoflavonas em produtos de soja, tem sido relatada como importante para a saúde humana. Foi sugerido também que esses compostos estariam envolvidos na proteção contra a radiação UV de componentes celulares vitais das plantas. A espectroscopia por ressonância paramagnética eletrônica (RPE) pode medir radicais livres resultantes do processo de irradiação. A RPE tem sido empregada com sucesso na detecção de certos produtos comestíveis irradiados. Ao todo vinte e uma cultivares brasileiras de soja, provenientes de duas safras, tratadas por radiação gama de ${ }^{60}$ Co foram estudadas através de RPE. Foi calculada a correlação entre os teores parciais e totais de isoflavonas e a intensidade do pico central observado nos espectros de RPE (fator $g=2,0039$ ). Não houve correlação entre o sinal e os teores totais de isoflavonas, mas observou-se correlações negativas com gliciteína e acetil-daidzina. Mesmo após 7 meses da irradiação, a intensidade do sinal central de RPE manteve-se a ponto de poder identificar amostras irradiadas. Espectros com partes da soja, particularmente o hilo e a casca, mostraram-se mais eficientes do que aqueles com o grão todo para serem utilizados na identificação de soja irradiada. A radiação não alterou de modo significativo os teores totais de isoflavonas, embora haja indícios de que alguma conversão da forma glicosilada para a aglicona tenha ocorrido. 


\title{
EVALUATION BY EPR OF POTENTIAL ANTIOXIDANT COMPONENTS OF ${ }^{60}$ CO-IRRADIATED VARIETIES OF SOYBEAN
}

\author{
Marcos Ronaldo Ramos de Oliveira
}

\begin{abstract}
Brazil is today the second main producer of soybean in the world with a planted ground of about 21 million hectares and an annual production of 60 million tons in 2008, being slight more than a fourth of the annual production. The presence of flavonoids, particularly isoflavones in soybean products has been related as important for human health. It has been suggested that flavonoids play a role in the protection of plants by screening vital cellular components from damaging UV radiation. Electron paramagnetic resonance (EPR) spectroscopy can measure free radicals produced by dissociation molecules resulting from irradiation. It has been successfully employed for the detection of some irradiated food products. Twenty one Brazilian soybean cultivars from two crops were gamma-irradiated with a ${ }^{60}$ Co source and evaluated by EPR. Correlation coefficients were made among the central EPR signal $(g=2.0039)$ and the total and partial isoflavones contents. There was no correlation with total contents, though glicitein and acetyl-daidzin showed a negative correlation. Even 7 months after irradiation the intensity of central EPR signal were high enough to distinguish the irradiated samples. EPR measurements of separated parts of the grain were more efficient for that purpose, particularly from hilum and coat. The radiation did not change substantially the total isoflavone contents, although there were some evidences suggesting some conversion of glycosides to aglycones.
\end{abstract}




\section{SUMÁRIO}

Página

\section{I.INTRODUÇÃO}

I.1 Considerações Gerais $\quad 01$

I.2 Objetivos 03

\section{II.REVISÃO DA LITERATURA}

II.1 A Soja $\quad 04$

II.2 Isoflavonas 07

II.3 Aplicação da irradiação em produtos alimentícios 11

II.3.1. Irradiação de Soja e Derivados 14

II.4. Ressonância Paramagnética Eletrônica 15

II.4.1 RPE em alimentos irradiados 18

\section{MATERIAL E MÉTODOS}

III.1. Material 20

III.2 Partes do grão 22

III.3. Cápsulas de Isoflavonas 23

III.4. Métodos 23

III.5 Espectroscopia por RPE $\quad 24$

\section{RESULTADOS E DISCUSSÃO}

IV.1. Efeito da radiação nas diversas cultivares 26

IV.2. Detecção por RPE de soja irradiada 32

IV.3. Correlação entre as concentrações totais ou parciais de isoflavonas com a intensidade do sinal 37

IV.4. Efeito da temperatura no sinal de RPE 41

IV.5. Sinal de RPE das diversas partes do grão de soja 43

IV.6. Efeito da radiação no conteúdo de isoflavonas 47 
IV.7. Pasta de Isoflavona

V. CONSIDERAÇÕES FINAIS

VI. CONCLUSÕES

58

APÊNDICE I

59

APÊNDICE II

63

APÊNDICE III

65

REFERÊNCIAS BIBLIOGRÁFICAS

69 


\section{LISTA DE FIGURAS}

Figura

Título

Página

1 Evolução da soja no mundo.

5

2 Estrutura geral das dicotiledôneas.

6

3 Estrutura química dos 12 isômeros de isoflavonas nas formas de 9 agliconas e de glucosídeos.

4 Diagrama ilustrando a ocorrência de ressonância entre os 16 estados de spin e o feixe de microondas.

5 Comparação entre o espetro de RPE de amostras BRM 52 - safra

26 2004/2005 não-irradiadas e irradiadas com doses de 2,5, 5,0, 10,0 e 15,0 kGy.

6 Espectro de RPE de amostra de soja moída e irradiada com 10 kGy. Leitura realizada com microondas de 0,5 mW.

7 RPE de cultivar BRS155 moída e irradiada com 10 kGy. Leitura cerca de 24 horas após a irradiação. A medida foi feita de uma vez, porém o resultado apresentado em dois gráficos, para facilitar o tratamento. Ganho do aparelho de $2 \times 10^{3}$.

8 Espectro de RPE de amostra de soja moída e não irradiada. No intervalo de campo magnético utilizado, notamos mais claramente os sinais A e B. A potência empregada foi de $10 \mathrm{~mW}$.

9 Espectro de RPE de amostra de soja moída não irradiada e irradiada com doses de 2,5, 5,0, 10,0 e 15,0 kGy. A potência empregada foi de $10 \mathrm{~mW}$.

10 Medidas de RPE para três cultivares moídas e não irradiadas. O intervalo de campo magnético utilizado mostra os picos 2,3 e 4 . A potência empregada foi de $10 \mathrm{~mW}$.

11 Espectros de RPE da cultivar BRS216, moída e irradiada com $15 \mathrm{kGy}$. Foram feitas oito leituras, com potências de microondas de $1 / 2,1,5,10,20,32,50$ e $100 \mathrm{~mW}$, aproximadamente.

12 Intensidade do sinal A (distância pico a pico) vs o tempo decorrido entre irradiação de $10 \mathrm{kGy}$ e a leitura. As medidas foram realizadas com três amostras da safra 2004/205. A irradiação ocorreu após a moagem.

13 Intensidade do sinal A em amostras cuja moagem ocorreu antes ou após a irradiação, com doses de 5 ou 10 kGy.

14 Intensidade do sinal central (pico a pico) versus dose absorvida para todas as amostras da safra 2004/05.

15 Intensidade do pico central das cultivares da safra 2004/05, irradiadas com doses de 2,5, 5,0, 10,0 e 15,0 kGy. As medidas foram feitas 4 dias após a irradiação. As amostras foram moídas antes de serem irradiadas. As intensidades são fruto de 5 leituras acumuladas. 16 Intensidade do pico central das cultivares da safra 2002/03, 
irradiadas com doses de 1, 4, 8 e $13 \mathrm{kGy}$. As medidas foram feitas 10 dias após a irradiação. As amostras foram moídas antes de serem irradiadas. As intensidades são fruto de 3 leituras acumuladas.

17 Intensidade do sinal RPE para cultivares da safra 2004/2005, irradiadas com doses: (a) 2,5 kGy, (b) $5.0 \mathrm{kGy}$, (c) $10.0 \mathrm{kGy}$ and (d) 15.0 kGy.

18 RPE da amostra BRS216, irradiada com $5 \mathrm{kGy}$ à temperatura de gelo seco: (1) medida à temperatura de nitrogênio líquido; (2) medida após 3 min de exposição da amostra a temperatura ambiente; (3) após 6 min de exposição; (4) releitura.

19 RPE da casca de três cultivares: não irradiada e irradiada com doses de 1 e 2 kGy.

20 RPE em hilo de três cultivares: não irradiado e irradiado com doses de 1 e 2 kGy.

21 RPE em cotilédones moídos de três cultivares: não irradiada e irradiada com doses de 1 e $2 \mathrm{kGy}$.

22 RPE em hipocótilo de três cultivares: não irradiado e irradiado com doses de 1 e 2 kGy.

23 Teor total de isoflavonas em cultivares de soja, safra 204/2005. As medidas foram feitas para amostras não irradiadas $e$ irradiadas com doses de 1, 2, 5 e $10 \mathrm{kGy}$.

24 Teores de isoflavonas do tipo daidzina em cultivares de soja, safra 204/2005. As medidas foram feitas para amostras não irradiadas e irradiadas com doses de 1, 2, 5 e $10 \mathrm{kGy}$.

25 Teores de isoflavonas do tipo glicitina em cultivares de soja, safra 204/2005. As medidas foram feitas para amostras não irradiadas e irradiadas com doses de 1, 2, 5 e 10 kGy.

26 Teores de isoflavonas do tipo genistina em cultivares de soja, safra 204/2005. As medidas foram feitas para amostras não irradiadas e irradiadas com doses de 1, 2, 5 e $10 \mathrm{kGy}$.

27 Teores de isoflavonas do tipo malonil-daidzina em cultivares de soja, safra 204/2005. As medidas foram feitas para amostras não irradiadas e irradiadas com doses de 1, 2, 5 e $10 \mathrm{kGy}$.

28 Teores de isoflavonas do tipo malonil-glicitina em cultivares de soja, safra $204 / 2005$. As medidas foram feitas para amostras não irradiadas e irradiadas com doses de 1, 2, 5 e $10 \mathrm{kGy}$.

29 Teores de isoflavonas do tipo malonil-genistina em cultivares de soja, safra 204/2005. As medidas foram feitas para amostras não irradiadas e irradiadas com doses de 1, 2, 5 e 10 kGy.

30 Teores de isoflavonas do tipo daidzeína em cultivares de soja, safra 204/2005. As medidas foram feitas para amostras não irradiadas e irradiadas com doses de 1, 2, 5 e $10 \mathrm{kGy}$.

31 Teores de isoflavonas do tipo gliciteína em cultivares de soja, safra 204/2005. As medidas foram feitas para amostras não irradiadas e irradiadas com doses de 1, 2, 5 e $10 \mathrm{kGy}$.

32 Teores de isoflavonas do tipo genisteína em cultivares de soja, 
safra 204/2005. As medidas foram feitas para amostras não irradiadas e irradiadas com doses de 1, 2, 5 e $10 \mathrm{kGy}$.

33 RPE de amostras de Isoflavine não-irradiadas e irradiadas com 54 doses de 2,5, 5,0 e 10,0 kGy.O intervalo ressalta apenas o que parece ser o sinal A, visto nas cultivares de soja.

34 RPE de Isoflavine e da cultivar BRS 155, ambas irradiadas com 55 10,0 kGy. 


\section{LISTA DE TABELAS}

Tabela

Título

Página

1 a) Composição aproximada da soja;

6

b) Conteúdo em minerais, vitaminas e fibra alimentar.

2 Composição lipídica e proteica das cultivares da safra 2004/05. 20

3 Composição lipídica e proteica das cultivares da safra 2002/03. 20

4 Conteúdos totais e parciais de isoflavonas das cultivares 21 2004/05, em mg/100g de material seco.

5 Conteúdos totais e parciais de isoflavonas das cultivares 22 2002/03, em mg/100g de material seco.

6 Parâmetros do ajuste de curvas dos dados experimentais para a intensidade do sinal central em função do tempo decorrido após as irradiações.

7 Parâmetros do ajuste de curvas dos dados dos gráficos da figura 14 à curvas do tipo exponencial.

8 Correlação linear entre o teor de isoflavona (total e parcial) das 07 cultivares da safra 2004/05 e a intensidade do sinal A (pico a pico).

9 Correlação linear entre o teor de isoflavona (total e parcial) das 14 cultivares da safra 2002/03 e a intensidade do sinal A (pico a pico).

Ap.I.a Distribuição t-Student (unicaudal). Ps é a probabilidade de que $t_{n-2} \geq t_{c r i t i c o}$, $g$. I. $=n-2$ é o número de graus de liberdade.

Ap.I.b Correlação linear entre a composição de isoflavonas (total e parcial) das 07 cultivares da safra 2004/05 e a intensidade do sinal A (pico a pico). Com 5 graus de liberdade tc $=2,015$, para $\alpha=5 \%$.

Ap.l.c Correlação linear entre a composição de isoflavonas (total e parcial) das 14 cultivares da safra 2002/03 e a intensidade do sinal A (pico a pico). Com 12 graus de liberdade, $t c=1,782$, para $\alpha=5 \%$.

Ap.III.a Isoflavonas em mg/100g para cultivares de soja não irradiadas e irradiadas com doses de 1, 5 e $10 \mathrm{kGy}$. Os valores expressam médias de duas medidas, descartadas variações acima de $5 \%$. As colunas d1, d2 e d3, trazem as diferenças entre os teores irradiados e não irradiados (doses de 1, 5 e 10 kGy respectivamente. 


\section{INTRODUÇÃO}

\section{I.1 Considerações Gerais}

Com uma área plantada de cerca de 21 milhões de hectares, e uma produção de quase 60 milhões de toneladas, o Brasil é hoje o segundo maior produtor de soja no mundo, com pouco mais de um quarto da produção mundial. Dados do Ministério do Desenvolvimento, Indústria e Comércio Exterior mostram que em 2006 a soja participou com US\$ 9,3 bilhões nas exportações brasileiras, o que representou $6,77 \%$ do total exportado. Embora contribua de maneira expressiva para a balança comercial do país, tradicionalmente boa parte da soja exportada sofre pouco ou nenhum processamento: grãos, $57 \%$; farelo, $36 \%$ e óleo, $7 \%$ (Embrapa, 2009).

Além das vantagens nutricionais, pois se trata de um grão rico em proteína e óleos não saturados, a soja é uma importante fonte natural de isoflavonas (uma classe dos flavonóides). As isoflavonas possuem ação antioxidante e seu consumo vem sendo associado a efeitos benéficos em seres humanos (Barnes, 1998), tais como prevenção de doenças cardiovasculares, câncer e osteoporose (Atmaca et. al, 2008), além de amenizar sintomas da menopausa (Adlercreutz \& Mazur, 1997; Anderson et al., 1995; Messina, 1999). Outro importante antioxidante encontrado na soja é a vitamina $E$ (tocoferóis).

Embora ainda pouco difundida no país, a irradiação de alimentos é prática em muitos países desenvolvidos e pode ser usada para reduzir as perdas na póscolheita da soja (Diehl, 2002). A radiação ionizante pode inativar insetos e parasitas ou melhorar propriedades tecnológicas. Os efeitos da radiação ionizante nas isoflavonas ou em outros compostos antioxidantes da soja não são conhecidos.

A radiação ionizante é capaz de liberar localmente grandes quantidades de energia, o que induz nos materiais biológicos um estresse oxidativo através da 
formação de radicais livres de alto grau de reatividade química. Swallow (1989) calculou que uma dose de $10 \mathrm{kGy}$ gera $5 \times 10^{-3}$ moles de radicais livres por $\mathrm{kg}$ de alimento irradiado.

A espectroscopia por ressonância paramagnética eletrônica (RPE) é uma técnica que permite quantificar e identificar radicais livres. Existem poucos trabalhos nos quais soja irradiada tenha sido estudada (Byun et al., 1993; Todoriki et al., 2002). Há alguns artigos que relatam medidas de RPE em pasta fermentada derivada de soja (Lee et al. 2001 e 2002) ou que estudam a cinética do íon $\mathrm{Mn}^{2+}$ (Polat \& Korkmaz, 2003) na leguminosa.

Estudos sobre isoflavonas em cultivares brasileiras são escassos (Àvila et al., 2007; Carrão-Panizzi, 1996, 2000; Carrão-Panizzi \& Kitamura, 1995; Carrão-Panizzi et al., 1998; Genovese \& Lajolo, 2001, 2002; Genovese et al., 2005; Bordignon et al., 2000), e muitas vezes já não correspondem às cultivares correntemente em uso. Diferentes cultivares de soja apresentam variações significativas nas concentrações de isoflavonas (Carrão-Panizzi, 1996).

O Brasil poderia agregar valor razoável às exportações se conhecesse melhor e tivesse condições de produzir e comercializar as isoflavonas em grande escala. $O$ mercado de isoflavonas está em franca expansão com as recentes pesquisas que apontam para seus benefícios à saúde humana, além de desempenhar um papel importante também no sabor da soja (Huang, 1981; Kudou, 1991 e Okubo, 1992).

Informações relativas aos impactos da radiação sobre o conteúdo de isoflavonas e outros constituintes da soja são limitados (Aguiar, 2004). O presente plano visa dar uma contribuição da energia nuclear para o melhor conhecimento dessa importante leguminosa $e, a$ partir do qual, pode-se propiciar o desenvolvimento de derivados de produtos agrícolas de maior valor agregado. 


\section{I.2.Objetivo}

O objetivo deste trabalho é o estudo através de espectroscopia por ressonância paramagnética eletrônica (RPE) de cultivares brasileiras convencionais de soja submetidas à radiação gama de ${ }^{60} \mathrm{Co}$. Pretende-se estabelecer a eficiência da RPE como método de detecção de soja irradiada, determinar a estabilidade do sinal em função do tempo, verificar se as concentrações de isoflavonas, componentes com atividade antioxidante, afetam a formação dos radicais detectados por RPE e se as concentrações de isoflavonas são alteradas ou não pela radiação. 


\section{REVISÃO DA LITERATURA}

\section{II.1. A Soja}

As origens da soja remontam à China antiga e datam de mais de 5 mil anos. No ocidente foi inicialmente implantada nos EUA e posteriormente trazida para o Brasil no final do século XIX, sendo cultivada primeiro na Bahia e posteriormente em São Paulo. Entretanto, foi apenas no Rio Grande do Sul que a variação norteamericana encontrou condições climáticas favoráveis ao seu cultivo.

Do ponto de vista econômico, o cultivo da soja no Brasil começa a ganhar importância econômica somente a partir da década de 1960, quando era plantada como a melhor alternativa de cultura após a colheita do trigo, plantado no inverno. Inicialmente a produção estava concentrada na região Sul e através de pesquisas realizadas pela Empresa Brasileira de Pesquisa Agropecuária (Embrapa) foram desenvolvidas variedades bastante produtivas também na região central do país, que desde 1980 teve um salto de produção fantástico, passando de $2 \%$ para quase $60 \%$ da produção nacional.

A expansão da soja trouxe uma série de benefícios para a agricultura do país, que hoje é o segundo maior produtor da leguminosa (FIG. 1), porém ainda com um potencial não explorado superior ao de seus principais concorrentes, sem prejuízo de outras culturas (Embrapa Soja, 2003). O Brasil exporta 75\% da produção na forma de grão, óleo ou farelo.

Uma das líderes do mercado de sementes de soja no Brasil, a Embrapa responde atualmente por $35 \%$ a $40 \%$ desse setor, estimando em 800 mil a 1 milhão de toneladas de sementes. Do total comercializado da Embrapa, quase a metade das sementes é de cultivares transgênicas. Estimativas apontam que $60 \%$ da safra nacional já é composta por soja transgênica (Vasconcelos, 2008) 


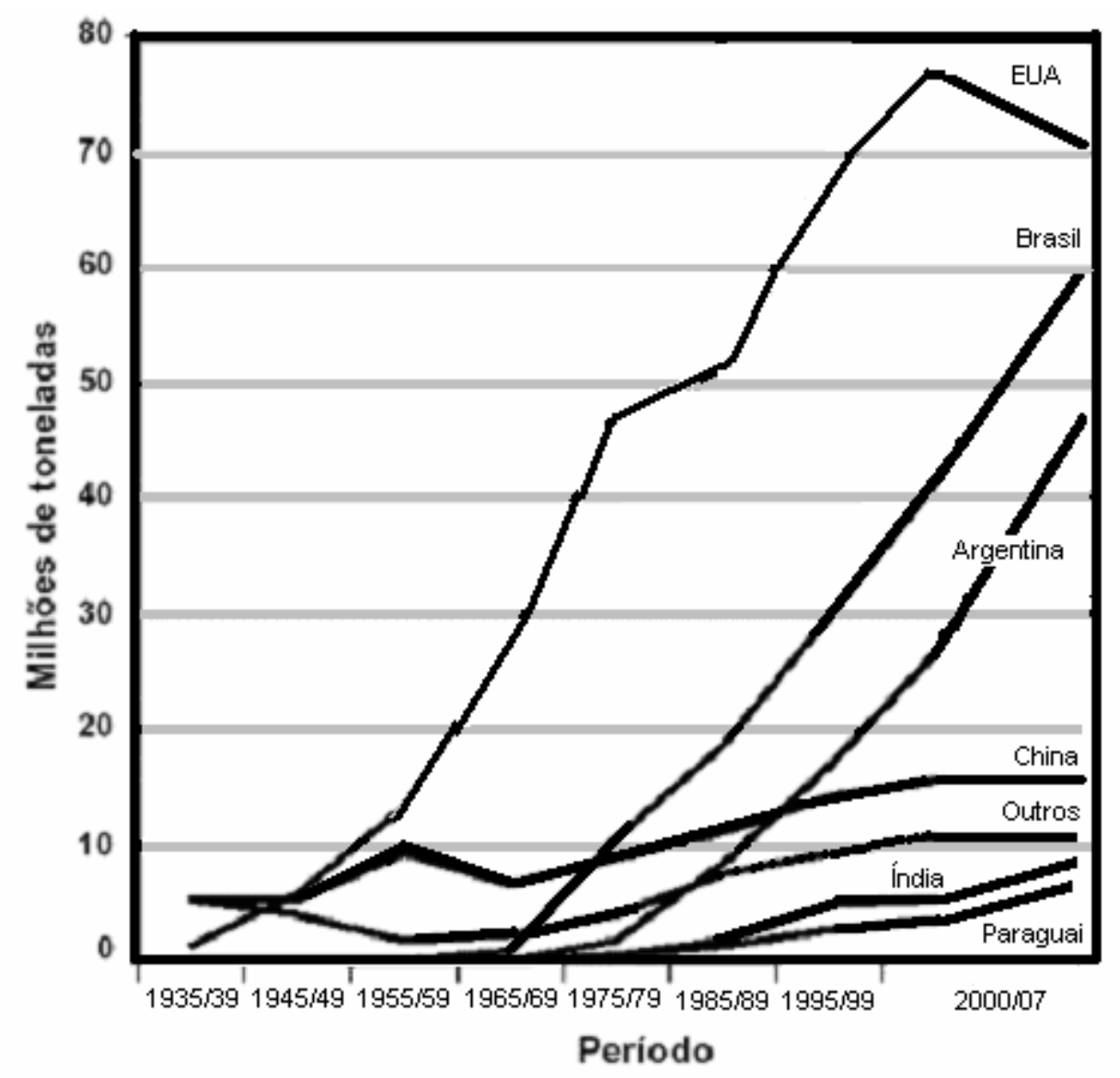

Figura 1: Evolução da produção de soja no mundo. Adaptado de USDA (Embrapa Soja, 2003).

A soja é uma cultura altamente rentável do ponto de vista econômico, quer seja por sua composição, rica em proteínas e óleos não saturados, quer seja pela facilidade de adaptação a diferentes tipos de solos e climas. Sua habilidade em fixar nitrogênio ao solo a favorece como a cultura ideal a ser plantada após a colheita de uma altamente consumidora de nitrogênio, como o arroz ou o milho (Liu, 2000).

Por ser uma cultura de tradição milenar, há um número muito grande de variedades de soja no mundo. A maioria foi selecionada ou alterada de maneira intencional pelo homem. Estas variedades cultivadas são denominadas cultivares, e variam bastante no que diz respeito ao tamanho dos grãos, coloração, sabor e outras 
características.

A casca do grão protege o seu interior, essencialmente constituído de duas bandas (cotilédones) e um eixo hipocótilo. Na casca há uma marca, semelhante a uma cicatriz, denominada hilo, que é o ponto de fixação do grão na vagem (FIG. 2). Os cotilédones representam cerca de $90 \%$ do grão. Casca e hipocótilo, contribuem, respectivamente, com $8 \%$ e $2 \%$. A leguminosa possui em média a seguinte composição: água, 13\%; proteína, 35\%; óleo, 17\%; carboidrato, $31 \%$ e outros constituintes, 4\% (Liu, 1997).

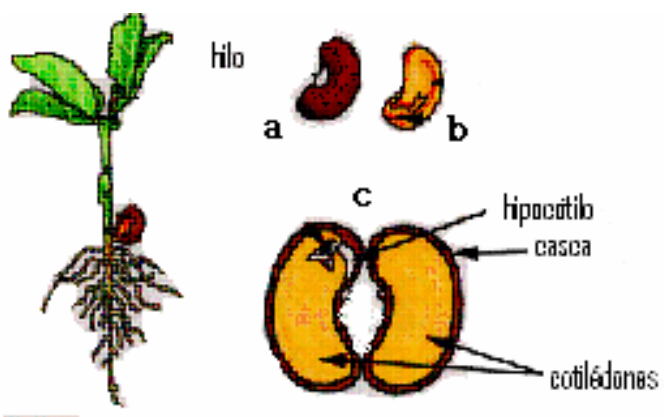

Figura 2: Estrutura geral das dicotiledôneas:(a) grão com casca; (b) sem casca e (c) grão em corte longitudinal, com suas partes constituintes.

A TAB. 1a apresenta a composição aproximada do grão de soja, de acordo com as suas partes estruturais. O hilo faz parte da casca. $\mathrm{Na}$ TAB 1b consta o conteúdo em minerais, vitaminas e fibra alimentar.

Tabela 1a: Composição aproximada da soja (Liu, 1997) \% do grão proteínas lipídios carboidratos Outros*

$\begin{array}{lccccc}\text { Casca } & 8 & 9 & 1 & 86 & 4,3 \\ \text { Hipocótilo } & 2 & 41 & 11 & 43 & 4,4 \\ \text { Cotilédone } & 90 & 43 & 23 & 29 & 5,0 \\ \text { Total } & 100 & 40 & 20 & 35 & 5,0 \\ \text { * Minerais, vitaminas, fitatos e isoflavonas. } & \end{array}$


Tabela 1b. Conteúdo em minerais, vitaminas e fibra alimentar (Kagawa, 1995).

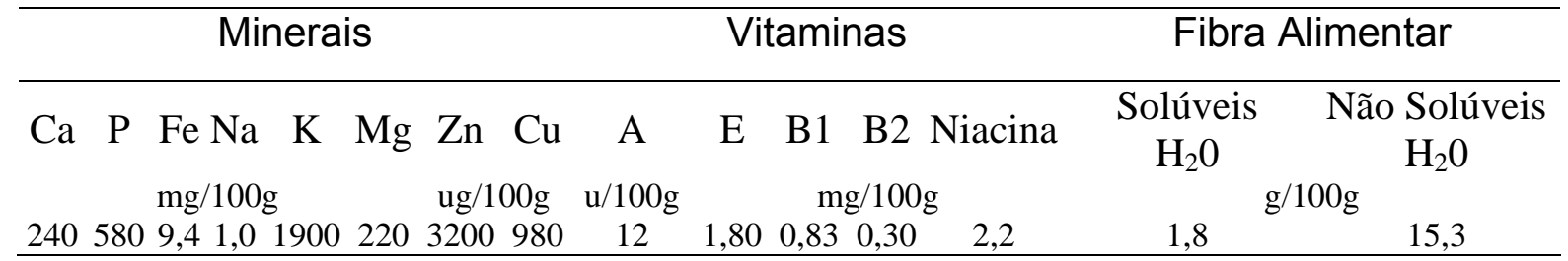

Além das vantagens nutricionais, a soja também vem sendo estudada por seus benefícios na prevenção e no tratamento de doenças crônico-degenerativas. Estudos epidemiológicos sugerem que o consumo regular de derivados de soja reduz a incidência de câncer de cólon, mama e próstata. Também é utilizada no tratamento de osteoporose, de sintomas associados a menopausa e doenças do coração, além de reduzir os níveis de colesterol (Atmaca et al., 2008; Song et. al, 2007).

Os antioxidantes mais comuns encontrados nos vegetais são quimicamente diversos, como as vitaminas $\mathrm{C}$ e E, carotenóides, flavonóides e compostos contendo o grupo tiol (Ou et al., 2002).

Antioxidantes naturais como os encontrados na soja são capazes de inibir a oxidação termicamente induzida de moléculas como é o caso da molécula de colesterol (Valenzuela et al, 2004).

\section{II.2. Isoflavonas}

Os flavonóides são importantes antioxidantes encontrados em todas as plantas superiores e muitos apresentam marcada absorção na região espectral de UVB. Tem sido sugerido que eles estariam envolvidos na proteção contra a radiação UV de componentes celulares vitais das plantas (Smith e Markham, 1996).

Há evidências cada vez maiores de que os responsáveis pelos efeitos 
benéficos da soja são substâncias químicas do grupo dos polifenóis como as isoflavonas (Liu, 2000; Anderson et al., 1995; Barnes, 1998; Messina, 1997 e 1999). As isoflavonas são também importantes na preparação de diversos produtos dietéticos, pois contribuem com o sabor amargo e adstringente observado nos derivados da soja (Matsuura, 1989).

As isoflavonas fazem parte de um grupo chamado de flavonóides, que são formados por dois anéis benzóicos ligados por uma ponte com três carbonos, ligados ou não a um anel pirano. Sua estrutura é semelhante ao estrógeno, hormônio feminino, daí também ser conhecido por fitoestrógeno.

As isoflavonas presentes na soja são de três tipos, cada um deles com quatro fórmulas químicas diferentes, totalizando 12 isômeros. Na forma de agliconas são denominados genisteína, daidzeína e gliciteína; na forma de $\beta$-glucosídeos: genistina, daidzina e glicitina; na forma acetilglucosídeo: acetilgenistina, acetildaidzina e acetilglicitina e, finalmente na forma malonilglicosídeo: malonilgenistina, malonildaidzina e malonilglicitina (Liu, 1997). A estrutura química de cada um desses isômeros está representada na FIG. 3. 
Agliconas

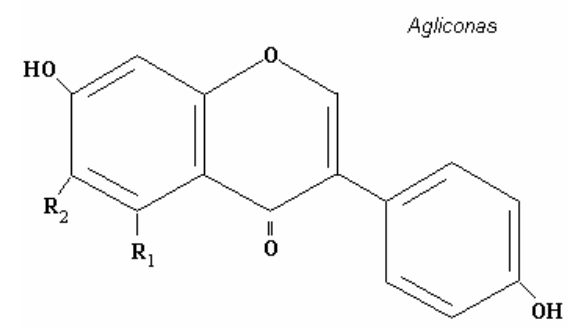

Glucosídeos

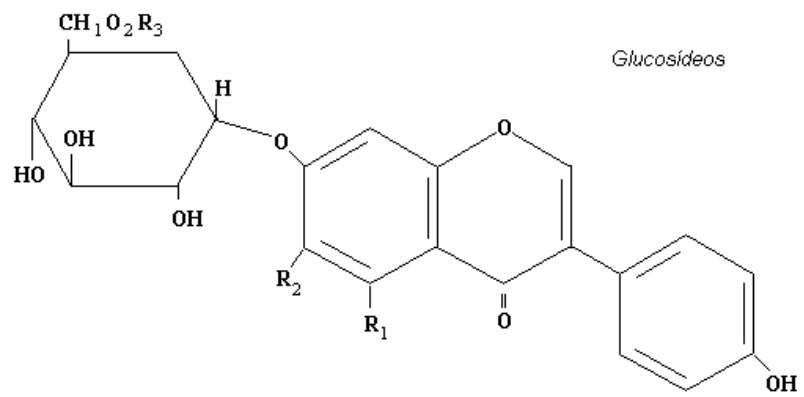

\begin{tabular}{|l|l|l|}
\hline $\mathbf{R}_{1}$ & $\mathbf{R}_{\mathbf{2}}$ & \multicolumn{1}{c|}{ Composto } \\
\hline $\mathrm{H}$ & $\mathrm{H}$ & daidzeína \\
\hline $\mathrm{OH}$ & $\mathrm{H}$ & genisteína \\
\hline $\mathrm{H}$ & $\mathrm{OCH}_{3}$ & gliciteína \\
\hline
\end{tabular}

\begin{tabular}{|l|l|l|l|}
\hline $\mathbf{R}_{\mathbf{1}}$ & \multicolumn{1}{|c|}{$\mathbf{R}_{\mathbf{2}}$} & \multicolumn{1}{|c|}{$\mathbf{R}_{\mathbf{3}}$} & \multicolumn{1}{c|}{ Composto } \\
\hline $\mathrm{H}$ & $\mathrm{H}$ & $\mathrm{H}$ & daidzina \\
\hline $\mathrm{OH}$ & $\mathrm{H}$ & $\mathrm{H}$ & genistina \\
\hline $\mathrm{H}$ & $\mathrm{OCH}_{3}$ & $\mathrm{H}$ & glicitina \\
\hline $\mathrm{H}$ & $\mathrm{H}$ & $\mathrm{COCH}_{3}$ & 6"'-O-acetildaidzina \\
\hline $\mathrm{OH}$ & $\mathrm{H}$ & $\mathrm{COCH}_{3}$ & 6"'-O-acetilgenistina \\
\hline $\mathrm{H}$ & $\mathrm{OCH}_{3}$ & $\mathrm{COCH}_{3}$ & 6"'-O-acetilglicitna \\
\hline $\mathrm{H}$ & $\mathrm{H}$ & $\begin{array}{l}\mathrm{COCH}_{2} \mathrm{CO} \\
\mathrm{OH}\end{array}$ & 6"'-O-malonildaidzina \\
\hline $\mathrm{OH}$ & $\mathrm{H}$ & $\begin{array}{l}\mathrm{COCH} \\
2\end{array}$ & 6"'-O-malonilgenistina \\
$\mathrm{OH}$ & $\mathrm{OCH}$ & $\begin{array}{l}\mathrm{COCH} \\
2\end{array}$ & 6"'-O-malonilglicitina \\
\hline $\mathrm{OH}$ & \\
\hline
\end{tabular}

Figura 3. Estrutura química dos 12 isômeros de isoflavonas nas formas de agliconas e de glucosídeos. Adaptado de Liu, 1997. 
Embora as isoflavonas sejam encontradas em diversas famílias de plantas, é na soja que elas estão em maiores concentrações, podendo chegar a $3 \mathrm{mg} / \mathrm{g}$ de matéria seca. Alguns trabalhos indicam que a concentração de isoflavonas não depende apenas da genética, mas também varia de acordo com as condições climáticas e o local de plantio (Ávila et al., 2007; Carrão-Pannizi, 1995; 1996; 1998 e Kitamura, 1991).

Com o processamento da soja para a obtenção de derivados, a concentração de isoflavonas pode ser modificada. Ainda de acordo com Coward et al. (1993), na maioria dos derivados fermentados asiáticos, predominam as agliconas. Wang e Murphy (1994) registraram que o processamento de soja para a elaboração de produtos fermentados de soja também conduzia a um aumento de agliconas, provavelmente ocasionado pela hidrólise durante a fermentação com Saccharomyces spp., Rhizopus spp.ou Aspergillus spp. Esses pesquisadores concluíram que o conteúdo de isoflavonas de produtos comerciais derivados de soja era afetado pela variedade (cultivar), condições ambientais de plantio e colheita, além do processamento (aquecimento, hidrólise e fermentação).

Já nos derivados não-fermentados, as isoflavonas se apresentam, sobretudo, na forma $\beta$-glucosídeo. A forma malonilglucosídica parece ser instável a altas temperaturas, convertendo-se na forma glucosídica (Barnes et al., 1994; Liu, 1997).

Kasuga et al. (2006) analisaram 6 cultivares de soja e encontraram grandes diferenças no conteúdo total de isoflavonas, maiores que 100\%. Também registraram decréscimo do conteúdo em $\beta$-glucosídeos e aumento de malonil-glucosídeos pelo aquecimento.

De acordo com Kudou et al. (1991), as isoflavonas estão concentradas no hipocótilo, com concentração de 5,5 a 6 vezes maior do que a do cotilédone; a forma glicitina foi observada apenas no hipocótilo e não se observou isoflavonas na casca. 
Dietas contendo isoflavonas são consideradas portadoras de benefícios para a saúde humana (Watanabe et al., 2002; Messina, 2008). As isoflavonas apresentam atividades biológicas tais como: atividades estrogênicas, antifúngicas, antioxidantes e antitumorais (mama e próstata), além de inibir a atividade de enzimas ligadas à divisão celular, sendo estas atividades biológicas mais acentuadas nas formas agliconas que glicosiladas (Aguiar, 2004).

Estudo recente sugere que o consumo de produtos de soja pode reduzir o risco de câncer colo-retal em mulheres pós-menopáusicas (Gong et al., 2009).

Em relação aos aspectos nutricionais e metabólicos dos flavonóides, sabe-se que os flavonóides glicosilados são primeiramente deglicosilados antes da absorção intestinal, já que as agliconas podem penetrar livremente através das membranas celulares. Os flavonóides absorvidos são transportados até o fígado onde eles sofrem intenso processo metabólico gerando diferentes formas conjugadas tais como: glicóis, e derivados sulfatados e metilados. Tem sido proposto que esses conjugados seriam responsáveis pelos efeitos benéficos para a saúde humana (Viskupicva et al. , 2008)

\section{3. Aplicação da irradiação em produtos alimentícios}

Na opinião da Organização Mundial da Saúde (WHO, 1999), a irradiação de alimentos é uma tecnologia que pode ser utilizada com segurança no controle dos mais sérios problemas relacionados com os alimentos: as perdas provenientes da deterioração e as doenças que podem ser ocasionadas pelo consumo de alimentos contaminados por microorganismos patogênicos (KAMAT, 2005). Por outro lado, pela sua capacidade de eliminar insetos e outras pragas, a irradiação oferece uma importante alternativa ao uso de produtos químicos como meio de atender os requerimentos quarentenários para a desinfestação de "commodities" para o comércio internacional. 
Em 1981, um comitê conjunto de especialistas em Salubridade de Alimentos Irradiados da Organização das Nações Unidas para a Agricultura e Alimentação (FAO), da Agência Internacional de Energia Atômica (IAEA) e da WHO concluiu que a irradiação de qualquer produto alimentício com dose média total de até 10 kGy não oferecia qualquer risco toxicológico ou problema de ordem microbiológica ou nutricional. Entretanto, num relatório de especialistas convocados pelas FAO/IAEA/WHO para estudar o efeito de altas doses de irradiação, concluiu-se que alimentos irradiados com doses acima de 10 kGy não causam nenhum risco de saúde para os consumidores (WHO, 1999). O Grupo Consultivo Internacional sobre Irradiação de Alimentos (ICGFI) foi criado em 1984, para estudar o tema e registrar os avanços, benefícios e a segurança dos alimentos tratados por irradiação ionizante. Foi um grupo de estudo conjunto da Organização das Nações Unidas para Agricultura e Alimentos (FAO), da Organização Mundial de Saúde (WHO), e da Agência Internacional de Energia Atômica (IAEA) encerrado em 2004. Uma das tarefas do ICGFI, órgão multigovernamental que contou com 46 países membros, era a de compilar informações sobre a utilização segura e apropriada da tecnologia de irradiação aos países membros (ICGFI, 1992).

O tratamento por irradiação é uma das alternativas de conservação de alimentos, já que não afeta de maneira adversa a qualidade do alimento. A história da irradiação de alimentos surgiu pouco depois do descobrimento da radioatividade $e$ dos raios $\mathrm{X}$, no final do século XIX, quando foi percebido que a radiação poderia ser aplicada para matar bactérias e retardar a germinação e amadurecimento de frutas e vegetais. A possibilidade do uso da irradiação, para prolongar o tempo de vida de certos alimentos, se tornou uma proposta prática a partir dos anos 50 , quando começaram a ser construídas instalações industriais de irradiação de grande porte. No Brasil a aplicação de radiação ionizante em produtos alimentícios começa na década de 1980 e até hoje se restringe praticamente a especiarias, e produtos vegetais desidratados (Mastro, 1999).

A radiação só pode acentuar as qualidades do alimento, que se já estiver 
deteriorado não poderá ser melhorado com esse processo. Segundo a legislação brasileira, no âmbito do Ministério da Saúde (Brasil, 2001), poderão ser utilizadas nos alimentos as radiações ionizantes em geral, cuja energia seja inferior ao limiar das reações nucleares que poderiam induzir radioatividade no material irradiado.

As radiações recomendadas (Codex, 2003) para aplicação em alimentos são:

- Raios gama de ${ }^{60} \mathrm{Co}\left(\mathrm{T}_{1 / 2}: 5,263\right.$ anos; $\beta^{-}: 0,314 \mathrm{MeV} ; \gamma: 1,173$ e $\left.1,332 \mathrm{MeV}\right) \mathrm{e}$

- Raios gama de ${ }^{137} \mathrm{Cs}\left(\mathrm{T}_{1 / 2}: 30\right.$ anos; $\beta^{-}: 0,514$ e $1,176 \mathrm{MeV}$, que decai a ${ }^{137 \mathrm{~m}} \mathrm{Ba}, \mathrm{T}_{1 / 2:}$ 2,554 min.; $\left.\gamma: 0,662 \mathrm{MeV}\right)$;

- Feixe de elétrons de até $10 \mathrm{MeV}$;

- Raios X de até $5 \mathrm{MeV}$.

$\mathrm{Na}$ atual legislação brasileira do Ministério da Saúde (Brasil, 2001), que deixou sem efeito as portarias anteriores, não há restrições a priori em relação a valores de doses a serem aplicados, não mais vigorando a lista restrita de alimentos autorizados para serem irradiados que constavam das Portarias: 9 de 8-3-1985 e 30 de 25-9-1989 do Ministério da Saúde. No texto da resolução hoje em vigor, fica estabelecido que:

a) "a dose mínima absorvida deve ser suficiente para alcançar a finalidade pretendida";

b) a dose máxima absorvida deve ser inferior àquela que comprometeria as propriedades funcionais e ou os atributos sensoriais do alimento".

Cabe destacar a abrangência da legislação do Brasil nesta matéria, uma vez que a maioria dos países proíbe, não tem legislação sobre alimentos irradiados, ou permite apenas a irradiação de alguns produtos.

Levando em consideração a sua importância econômica, a Agência 
Internacional de Energia Atômica publicou um documento técnico sobre o uso da radiação em produtos de origem vegetal (IAEA, 2006).

É importante salientar que para cada aplicação específica da radiação em alimentos existe uma faixa de dose adequada recomendada pelos especialistas com base nos estudos publicados na literatura. A aplicação de radiação pode ser dividida em 3 categorias: dose alta (>10kGy), dose média (1-10kGy) e dose baixa ( $\leq 1 \mathrm{kGy}$ ). Em doses altas os alimentos são esterilizados, como no processo comercial de conserva de alimentos. Em doses médias, há um efeito de pasteurização, onde a vida de prateleira é prolongada e a maioria dos microorganismos patogênicos são destruídos ou inativados. Nas doses baixas o produto é desinfetado, ou seja, são eliminados insetos e outras pragas, e a maturação de frutas e vegetais é retardada (Olson, 1995).

\section{3.1. Irradiação de Soja e Derivados}

Foram encontrados na literatura alguns trabalhos sobre soja e derivados tratados com radiação. Day et al. (2008), descrevem a capacidade radioprotetora da genisteína. Estudos realizados com camundongos mostraram que a genisteína exercia ação protetora contra danos induzidos pela radiação.

Lee et al. $(2001,2002)$ utilizaram RPE para estudar uma pasta fermentada de soja. Os autores analisaram o comportamento do sinal de RPE em função da dose de irradiação, temperatura e teor de umidade.

Há também estudos com soja que investigam as mudanças de certas propriedades físicas da soja irradiada. Byun et al. (1993), observaram um aumento da capacidade de retenção de água da soja irradiada, e uma diminuição do tempo de cozimento, comparada com a soja não-irradiada. Todoriki et al. (2002) verificaram a eficiência do tratamento de soja com elétrons de baixa energia em associação com tratamentos térmicos, com a finalidade de reduzir as temperaturas de esterilização. 
Byun et al. (1996 e 2002) relatam propriedades físico-químicas de óleo de soja irradiada e variações na atividade fisiológica de fermentados à base de soja, respectivamente.

\section{II.4. Ressonância Paramagnética Eletrônica}

A técnica de Ressonância Paramagnética eletrônica (RPE), também conhecida por Ressonância de Spin Eletrônico (RSE), se limita ao estudo de elétrons desemparelhados. Nas ligações químicas os elétrons estão geralmente pareados, com um spin para baixo e outro para cima $(\downarrow \uparrow)$. Nos radicais livres e outras espécies paramagnéticas, os spins estão desemparelhados, existindo em quaisquer daqueles estados $(\downarrow$ ou $\uparrow)$.

O spin, ou momento angular intrínseco, é uma propriedade de todas as partículas elementares. A manifestação mais óbvia do spin é o fato do elétron possuir um momento magnético $\left(\mu_{\mathrm{e}}\right)$. Classicamente, é o que se poderia esperar de uma esfera carregada que girasse em torno de seu próprio eixo, muito embora o valor de $\mu_{\mathrm{e}}$ não corresponda exatamente àquela situação (Atherton, 1993).

$\mathrm{O}$ momento angular intrínseco $\mathbf{S}$ do elétron e seu momento magnético $\boldsymbol{\mu}_{\mathrm{e}}$, podem ser relacionados através da equação 1 :

$$
\vec{\mu}_{e}=-g_{e} \mu_{B} \vec{S}
$$

onde ge $\approx 2,0023$ (fator g para o elétron livre ${ }^{1}$ ) e $\mu_{B}=\frac{e \hbar}{2 m_{e}} \approx 9,274.10^{-24} \mathrm{~J} / T$ é o magneto de Bohr .

\footnotetext{
${ }^{1}$ Numa situação real, o elétron não está livre e a constante ge é substituída por g.
} 
De acordo com a mecânica quântica, os dois estados de spin $\left(m_{s}=-1 / 2\right.$ e $m_{s}=1 / 2$ ) possuem a mesma energia ${ }^{2}$. Entretanto, se o elétron for colocado na presença de um campo magnético Bo, os dois estados passam a ter energias distintas, cuja diferença é proporcional ao campo aplicado de acordo com a equação 02 (efeito Zeeman). Diz-se que o campo magnético quebrou a degenerescência dos estados de spin:

$$
\Delta E=g_{e} \mu_{B} B_{o}
$$

A técnica de RPE consiste, grosso modo, em provocar uma transição entre esses estados, através da excitação da amostra com um feixe de fótons com energia igual à diferença entre os dois níveis. Nas medidas de RPE, o que se faz é fixar um certo valor para o feixe de fótons (na faixa de microondas, $\mathrm{GHz}$ ) e varrer a intensidade do campo magnético até atingir a condição de ressonância (FIG.4), isto é, $\Delta E=h v$.

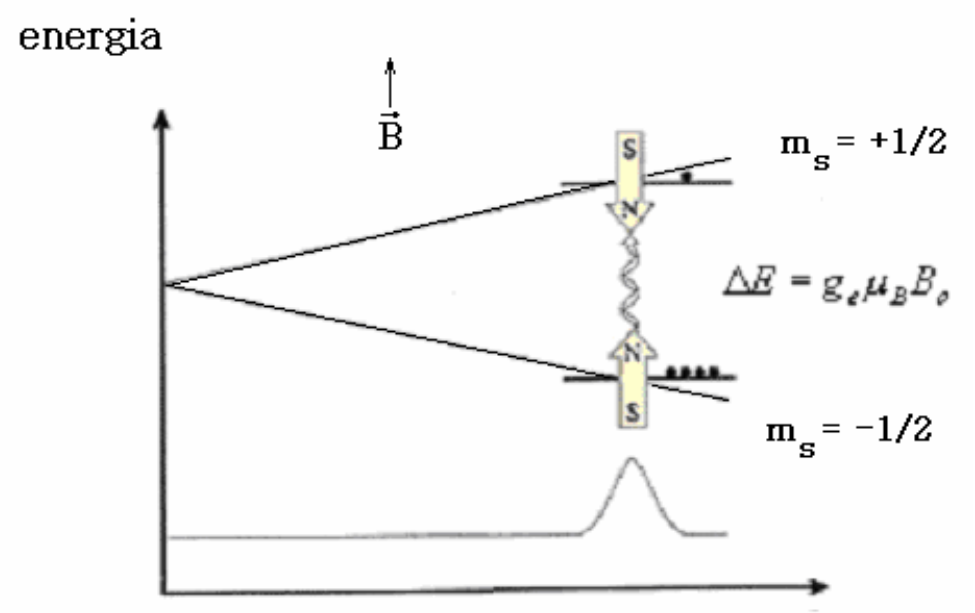

campo magnético, Bo

Figura 4: Diagrama ilustrando a ocorrência de ressonância entre os estados de spin e o feixe de microondas.

\footnotetext{
${ }^{2}$ Na prática, pode haver um desdobramento devido aos campos internos, dos próprios átomos. É o que se chama de desbobramento de campo-zero.
} 
Para que haja sinal é necessário que exista uma diferença entre as populações de spin nos dois estados. No equilíbrio térmico a razão entre as populações de spin no estado de menor e de maior energia é dada por um termo do tipo Boltzmann, i.e., $\exp (-\Delta E / k T)$. A radiação tende a equilibrar as populações até que ocorra a saturação do sinal (Parish, 1990).

Além do campo magnético Bo, há outros fatores que afetam o comportamento do spin e que são propriamente estudados através da introdução de outros termos na hamiltoniana que descreve as transições entre os estados. Assim, além da interação com o campo magnético, pode-se observar também outros picos resultantes, por exemplo, das interações hiperfinas, entre o spin do elétron e o spin do núcleo, ou entre dois elétrons (Parish, 1990).

Para sistemas de spin $S$, há um total de $2 S+1$ estados de energia, caracterizados pelos números quânticos $\mathrm{m}_{\mathrm{s}}$. Com a aplicação do campo magnético os níveis de energia são separados e em princípio podem ocorrer $2 S$ transições, de acordo com as regras de seleção $\left(\Delta m_{s}= \pm 1\right)$. O surgimento de mais de uma linha no espectro de ressonância é chamado de estrutura fina (Parish, 1990).

Se o elétron desemparelhado circunda um átomo que também possui spin I, então há um desdobramento dos níveis de energia dos estados de spin eletrônico. Cada estado eletrônico é separado em $21+1$ estados. Desta forma o espectro é desdobrado em 2I+1 linhas de igual intensidade e separadas por de uma distância A, chamada de constante de acoplamento hiperfino. Se o elétron estiver "espalhado" por $n$ átomos equivalentes, de spin I, então o desdobramento se dará em $2 \mathrm{nl}+1$ linhas (Parish, 1990).

Se a interação do elétron ocorre com $n$ prótons equivalentes $(I=1 / 2)$, então haverá superposição de picos, devido ao valor das constantes de acoplamento serem aproximadamente iguais. Neste caso, a razão entre as intensidades dos picos será dado pelos coeficientes de uma expansão binomial $(a+b)^{n}$. Assim, para $n=2$, 
observar-se-á um tripleto com intensidades 1:2:1. Se a interação hiperfina for com 3 prótons, o quarteto terá picos na razão 1:3:3:1, e assim por diante, conforme o diagrama abaixo (Atherton, 1993).

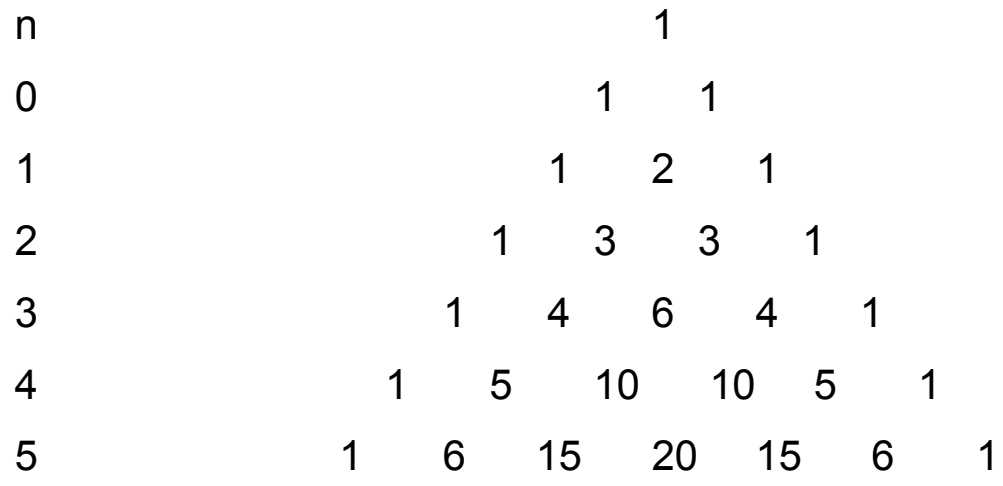

No caso dos radicais formados serem estáveis, isto é, estarem ligados a alguma matriz, a amplitude do sinal de RPE (ou mais precisamente, a área sobre a curva) é aproximadamente proporcional à quantidade de elétrons desemparelhados.

\section{II.4.1. RPE em alimentos irradiados}

Há estudos que utilizam o sinal de RPE induzido em quartzo, carbonatos ou em ossos para datação arqueológica (Ikeya e Miki, 1980; Mascarenhas et al., 1982).

A espectroscopia por RPE é considerada uma das mais importantes formas de se detectar radicais livres em alimentos. Estima-se que uma dose de $10 \mathrm{kGy}$ gera para cada quilograma de alimento, cerca de $5 \times 10^{-3}$ mol de radicais livres (Glidwell,1993). Além de servir como um instrumento de quantificação dos radicais livres, a técnica também permite caracterizar o tipo de radical presente na amostra (Diehl, 1995).

A utilização da RPE em alimentos está bastante consolidada, em especial na identificação de diversos tipos de carnes com ossos (Desrosiers and Simic, 1998; 
Goodman et al., 1989; Raffi e Agnel, 1990; Atta et al., 2008), ervas, especiarias e frutas (Raffi et al., 2000; Nakamura et al. 2006) em condimentos e frutas secas (Yang et al., 1987), café (Ikeya et al., 1989), chás (Kausar, e Kwon, 2004;) e trigo (Szöcs, 2002 e Barros, 2002) irradiados.

Após estudos interlaboratoriais para fixar a metodologia e suas limitações, a Comunidade Europeia estabeleceu normas que utilizam RPE para a detecção de alimentos irradiados que contenham ossos (EN-1786) e para alimentos irradiados que contenham celulose cristalina (EM-1787) tais como pistache, páprica e morango (European Norms, 2001). 


\section{MATERIAL E MÉTODOS}

\section{1 Material. Cultivares de Soja}

Foram estudadas cultivares convencionais de soja fornecidas pela Empresa Brasileira de Pesquisa Agropecuária (Embrapa Soja, PR.). Num primeiro momento foram empregadas 14 cultivares da safra 2002/03 e posteriormente, outras 7 da safra 2004/05 - ambas colhidas em Londrina/PR. Os conteúdos de proteínas e óleos foram obtidos junto à Embrapa (TAB. 2 e 3).

Tabela 2. Composição lipídica e proteica das cultivares da safra 2004/05.

\begin{tabular}{lrc}
\multicolumn{1}{l}{ cultivar } & óleo (\%) & proteína (\%) \\
\hline BRS 155 & 22,6 & 41,0 \\
BRS 156 & 21,6 & 38,6 \\
BRS 183 & 20,6 & 40,6 \\
BRS 216 & 17,6 & 43,6 \\
BRS 231 & 21,2 & 40,2 \\
BRS 233 & 19,5 & 40,9 \\
BRM 52 & 20,6 & 39,1 \\
\hline
\end{tabular}

Tabela 3. Composição lipídica e proteica das cultivares da safra 2002/03 (Embrapa Soja, 2003).

\begin{tabular}{lcc}
\hline \multicolumn{1}{c}{ cultivar } & óleo (\%) & proteína (\%) \\
\hline BRM 52 & n.d. & n.d. \\
BRS 155 & 22,6 & 40,6 \\
BRS 156 & 21,6 & 43,6 \\
BRS 183 & 20,6 & 40,6 \\
BRS 184 & 24,2 & 39,0 \\
BRS 185 & 22,5 & 39,8 \\
BRS 212 & 19,9 & 38,0 \\
BRS 213 & 19,0 & 39,7 \\
BRS 214 & 20,6 & 39,0 \\
BRS 215 & 20,0 & 39,5 \\
BRS 216 & 17,6 & 43,6 \\
BRS 230 & 21,4 & 40,9 \\
BRS 231 & n.d & n.d. \\
BRS 233 & 20,7 & 40,6 \\
\hline
\end{tabular}

\footnotetext{
${ }^{3}$ Recebida da Embrapa como BRM 52, ou BRM simplesmente. Posteriormente ganhou o status de cultivar e foi denominada BRS 267 . 
A composição de isoflavonas foi obtida através de análises junto à Faculdade de Ciências Farmacêuticas da Universidade de São Paulo (Dra. Maria Inês Genovese, comunicação pessoal) e da própria Embrapa (Dr. J. Marcos Mandarino, comunicação pessoal) para as safras 2002/03 e 2004/05 respectivamente. Para melhor comparação os dados obtidos foram colocados numa mesma base, isto é, em massa equivalente de agliconas (TAB. 4 e 5). É importante ressaltar que apesar de cultivares de safras diferentes possuírem o mesmo nome, as composições de isoflavonas podem ser consideravelmente distintas, pois as condições climáticas do plantio podem influenciar bastante na composição de cada safra (Carrão-Panizzi, 1998; Ávila, 2007).

Tabela 4. Conteúdos totais e parciais de isoflavonas das cultivares 2004/05, em $\mathrm{mg} / 100 \mathrm{~g}$ de material seco (dados fornecidos pelo EMBRAPA-Apêndice II).

\begin{tabular}{lc|ccc|ccc|cc} 
& \multicolumn{4}{c}{ beta-glucosídeo } & \multicolumn{3}{c}{ malonil-glucosídeo } & \multicolumn{2}{c}{ aglicona } \\
\cline { 3 - 9 } cultivar & total & daidzina & glicitina & genistina & daidzina & glicitina & genistina & daizeína & genisteína \\
\hline BRM 52 & 128,7 & 23,8 & 49,2 & 14,9 & 2,6 & 2,7 & 26,3 & 5,1 & 4,1 \\
BRS155 & 101,8 & 19,4 & 6,7 & 26,1 & 17,9 & 5,6 & 19,7 & 3,9 & 2,7 \\
BRS 156 & 113,2 & 13,7 & 17,5 & 28,0 & 8,4 & 8,4 & 32,5 & 2,9 & 1,9 \\
BRS 183 & 77,0 & 9,2 & 16,1 & 13,5 & 6,5 & 6,6 & 25,2 & 0,0 & 0,0 \\
BRS 216 & 79,4 & 10,3 & 18,2 & 12,8 & 8,0 & 8,1 & 19,2 & 1,6 & 1,2 \\
BRS 231 & 68,1 & 9,6 & 6,8 & 7,4 & 19,9 & 9,9 & 14,5 & 0,0 & 0,0 \\
BRS 233 & 124,9 & 12,9 & 31,9 & 19,8 & 8,3 & 8,4 & 40,2 & 2,0 & 1,4 \\
\hline
\end{tabular}


Tabela 5. Conteúdos totais e parciais de isoflavonas das cultivares 2002/03, em $\mathrm{mg} / 100 \mathrm{~g}$ de material seco (Genovese et al., 2005).

\begin{tabular}{|c|c|c|c|c|c|c|c|c|c|c|c|c|}
\hline \multirow[t]{2}{*}{ cultivar } & \multirow[t]{2}{*}{ total } & \multicolumn{3}{|c|}{ beta-glucosídeo } & \multicolumn{3}{|c|}{ malonil- glucosídeo } & \multicolumn{3}{|c|}{ aglicona } & \multicolumn{2}{|c|}{ acetil-glucos. } \\
\hline & & $\begin{array}{l}\text { daidzina } \\
\end{array}$ & $\begin{array}{l}\text { glicitina } \\
\end{array}$ & genistina & \begin{tabular}{|l|} 
daidzina \\
\end{tabular} & glicitina & genistina & \begin{tabular}{|l|} 
daizeina \\
\end{tabular} & gliciteina & genisteína & daidzin & genistina \\
\hline BRM 52 & $57(1)$ & 10,8 & 5,6 & 14,2 & 5,5 & 2,7 & 8,2 & 1,6 & 1,7 & 3,0 & 3,3 & 0,6 \\
\hline BRS 155 & $113(4)$ & 23,8 & 9,2 & 31,5 & 12,3 & 3,4 & 19,1 & 2,4 & 1,4 & 3,8 & 5,1 & 1,2 \\
\hline BRS 156 & $188(12)$ & 52,0 & 13,0 & 45,4 & 22,7 & 4,4 & 25,6 & 7,2 & 3,1 & 7,7 & 5,5 & 1,5 \\
\hline BRS 183 & $105(4)$ & 21,1 & 6,8 & 27,0 & 12,4 & 3,5 & 21,8 & 2,5 & 1,9 & 2,9 & 3,9 & 1,1 \\
\hline BRS 184 & $112(3)$ & 23,4 & 5,3 & 27,4 & 14,6 & 2,6 & 22,0 & 4,2 & 1,9 & 5,2 & 4,1 & 1,6 \\
\hline BRS 185 & $128(3)$ & 28,8 & 8,5 & 28,6 & 21,4 & 3,2 & 25,0 & 2,2 & 2,1 & 2,5 & 4,6 & 1,1 \\
\hline BRS 212 & $134(13)$ & 25,1 & 4,5 & 37,1 & 14,9 & 4,8 & 31,9 & 2,7 & 2,4 & 4,0 & 5,3 & 1,2 \\
\hline BRS 213 & $131(4)$ & 29,5 & 8,5 & 35,5 & 15,1 & 3,0 & 22,3 & 3,6 & 2,7 & 4,8 & 4,6 & 1,2 \\
\hline BRS 214 & $85(2)$ & 20,0 & 8,8 & 18,0 & 12,1 & 2,7 & 11,5 & 1,5 & 1,9 & 3,0 & 4,8 & 0,9 \\
\hline BRS 215 & $131(4)$ & 28,3 & 7,0 & 31,2 & 18,3 & 4,3 & 26,0 & 3,7 & 2,3 & 3,8 & 4,7 & 1,3 \\
\hline BRS 216 & $116(11$ & 25,3 & 10,4 & 28,7 & 16,5 & 3,0 & 21,3 & 1,7 & 1,5 & 3,0 & 3,4 & 1,0 \\
\hline BRS 230 & $57(1)$ & 11,1 & 2,5 & 17,8 & 5,7 & 1,0 & 11,6 & 1,5 & 1,1 & 2,5 & 2,1 & 0,5 \\
\hline BRS 231 & $137(1)$ & 32,7 & 8,3 & 28,8 & 23,8 & 4,8 & 23,6 & 3,7 & 2,0 & 3,6 & 4,6 & 1,0 \\
\hline BRS 233 & 130(9) & 24,0 & 9,7 & 37,7 & 14,0 & 4,8 & 28,2 & 1,7 & 1,4 & 2,9 & 4,5 & 0,9 \\
\hline
\end{tabular}

As amostras de soja foram trituradas em um moedor de café portátil e a seguir peneiradas, eliminando-se os restos com diâmetro superior a $1,5 \mathrm{~mm}$. O pó obtido de cada uma das cultivares foi então dividido em pacotes plásticos para que fossem irradiados.

\section{III.2 Partes do Grão}

Os grãos de três cultivares (safra 2004/05) foram separados em suas partes constituintes: casca, hilo, cotilédone e hipocótilo (FIG.2). Com cada cultivar, agora dividido em quatro porções, foram feitas três sub-amostras, duas irradiadas, com doses de 1 e $2 \mathrm{kGy}$, e a outra não irradiada. A casca e o cotilédone foram moídos antes das leituras de RPE. O hipocótilo e o hilo, por serem bem menores não foram moídos, mas simplesmente fragmentados quando necessário, para que coubessem nos tubos de RPE. 
III.3 Cápsulas de Isoflavonas

Cápsulas de isoflavonas, comercialmente disponíveis como Isoflavine (Glycine max 75 mg - Herbarium Laboratorio Botanico Ltda) e de consistência gelatinosa, também foram estudadas. De acordo com o laboratório responsável pelo produto, cada cápsula de $75 \mathrm{mg}$ contém cerca de $30 \mathrm{mg}$ de isoflavonas de soja.

\section{III.4 Métodos}

Irradiação

As irradiações foram realizadas numa fonte de ${ }^{60} \mathrm{Co}$ (Gammacell 220 - AECL) localizada no Centro de Tecnologia das Radiações do IPEN, com taxa de dose ao redor de $3 \mathrm{kGy} / \mathrm{h}$, fator de uniformidade de dose de 1,1. Os pacotes de cultivares foram irradiados com doses de até $15 \mathrm{kGy}$. Para comparação posterior, foi mantido um pacote de cada cultivar sem irradiação.

A dosimetria foi realizada através de dosímetros fabricados pela Harwell Dosimeters Ltd, de fabricação britânica, do tipo Amber, para a faixa de doses de 1 a 30 kGy. Foram inseridos três dosímetros (Amber 3042 Batch P) em posições diferentes nos pacotes de algumas cultivares moídas. As leituras dosimétricas basearam-se em mudanças óticas sofridas pelo dosímetros, registradas através de dispositivo espectrofotométrico. Foram observadas variações máximas de até $4 \%$ entre o valor nominal da dose e o valor médio registrado pelos três dosímetros. Em média, aquela diferença ficou em torno de $2,8 \%$.

Nos estudos da variação do teor de isoflavonas com a radiação, as amostras foram enviadas pelo correio para o Laboratório da Embrapa, em Londrina/PR.

As cápsulas de isoflavonas (isoflavine) foram irradiadas com as seguintes doses: 2,5, 5,0 e 10,0 kGy. Também foram mantidas algumas cápsulas não irradiadas. 


\section{III.5 Espectroscopia por Ressonância Paramagnética Eletrônica}

Foi estudada a contribuição para a formação do sinal de ressonância, de cada uma das partes do grão. Posteriormente, foi analisada a pasta de isoflavonas, comercialmente disponível em farmácias.

As medidas de RPE das cultivares foram feitas em um intervalo que variou de 1 dia a 7 meses após a irradiação, em um espectrômetro de banda X (ER 041 XG Microwave Bridge - Bruker) do Laboratório de Biofísica da Universidade de São Paulo (IFUSP). As amostras foram colocadas em tubos de quartzo com diâmetros interno e externo de 4,75 e 5,75, respectivamente, e abertura selada com material plástico durante as medidas.

Quando não estavam sendo utilizadas, as amostras eram mantidas em refrigerador, com temperatura próxima a $5^{\circ} \mathrm{C}$. A menos que expressamente indicado, os parâmetros do equipamento de RPE foram os seguintes:

$\begin{array}{ll}\text { ganho do receiver , } & 6,32 \times 10^{4} ; \\ \text { amplitude de modulação, } & 2,0 \mathrm{G} ; \\ \text { tempo de conversão, } & 81.92 \mathrm{~ms} ; \\ \text { constante de tempo } & 327,68 \mathrm{~ms} ; \\ \text { tempo de varredura, } & 83,886 \mathrm{~s} \text { (sweep time); } \\ \text { potência de microondas, } & 5-10 \mathrm{~mW} ; \\ \text { frequência de microondas, } & \approx 9,8 \mathrm{GHz} \\ \text { número de medidas sobrepostas } & 5\end{array}$

Para garantir a fidelidade dos valores do campo magnético, foi utilizada uma amostra de prova de Diphenyl-picryl-hydrazyl (DPPH), cujo fator g é bem conhecido. Ao longo dos estudos também foram utilizadas amostras de referência (strong pitch), com um número constante de radicais livres, objetivando-se averiguar a sensibilidade 
do equipamento.

De uma forma geral, tanto a irradiação quanto as medidas de RPE, ocorreram à temperatura ambiente. No entanto, houve algumas medições a baixas temperaturas, que são apresentados nos resultados, mas que por uma questão de praticidade não foram o foco deste trabalho.

As medidas com a pasta de isoflavonas foram feitas em tubos de quartzo menores, com cerca de 1,0 mm de diâmetro. Foi utilizada uma cápsula por tubo, e o intervalo entre irradiação e leitura, foi de apenas algumas poucas horas. 


\section{RESULTADOS E DISCUSSÃO}

IV.1 Efeito da radiação nas diversas cultivares

As amostras de soja não-irradiadas apresentaram um sinal de RPE insignificante à temperatura ambiente, se comparado com o observado em amostras irradiadas. $O$ aspecto geral das curvas para ambas as safras foi essencialmente 0 mesmo, dentro das mesmas condições de medida (FIG. 5 e 6), com variações apenas nas intensidades dos picos.

De acordo com a potência de microondas empregada, as cultivares apresentaram 3 sinais de RPE à temperatura ambiente: um singleto (sinal $A$ ), um sexteto (sinal B) e um dupleto (sinal C). Para diferenciar os picos nos sinais compostos, utilizou-se um número ao lado da letra respectiva que identifica o pico. Assim, B2 indica o segundo pico do sinal B, contando no sentido crescente do campo magnético, ou decrescente do valor de g.

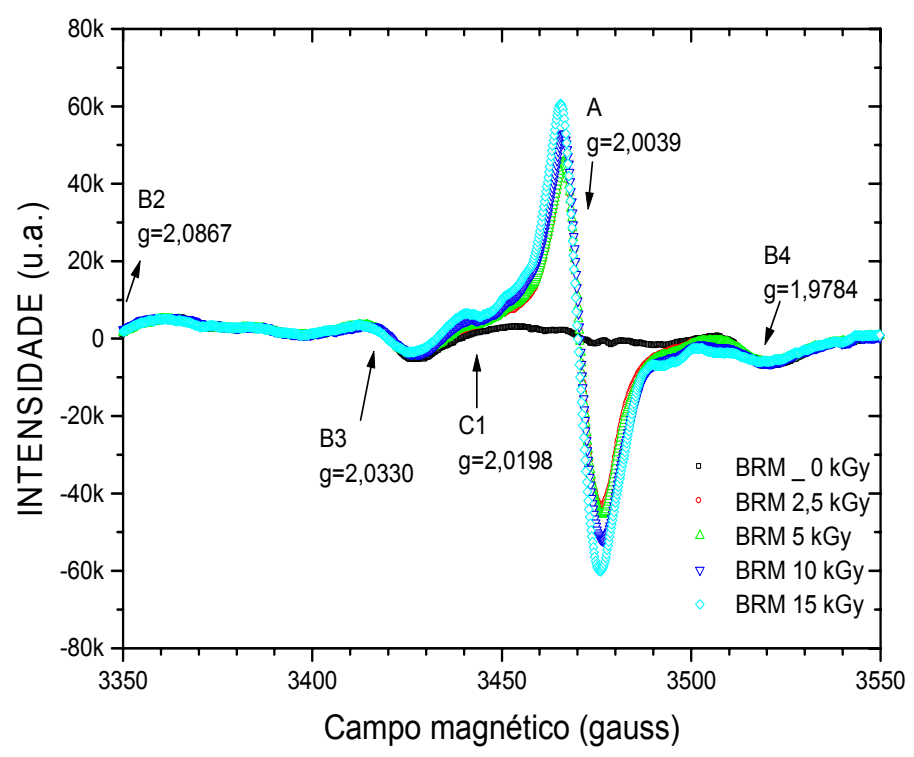

Figura 5. Comparação entre o espetro de RPE de amostras BRM 52 safra 2004/2005 não-irradiadas e irradiadas com doses de 2,5, 5,0, 10,0 e 15,0 kGy. Medidas 4 dias após irradiação. 
Na FIG. 6 estão em evidência os sinais A e C, bem como parte do sexteto (B3 e B4).

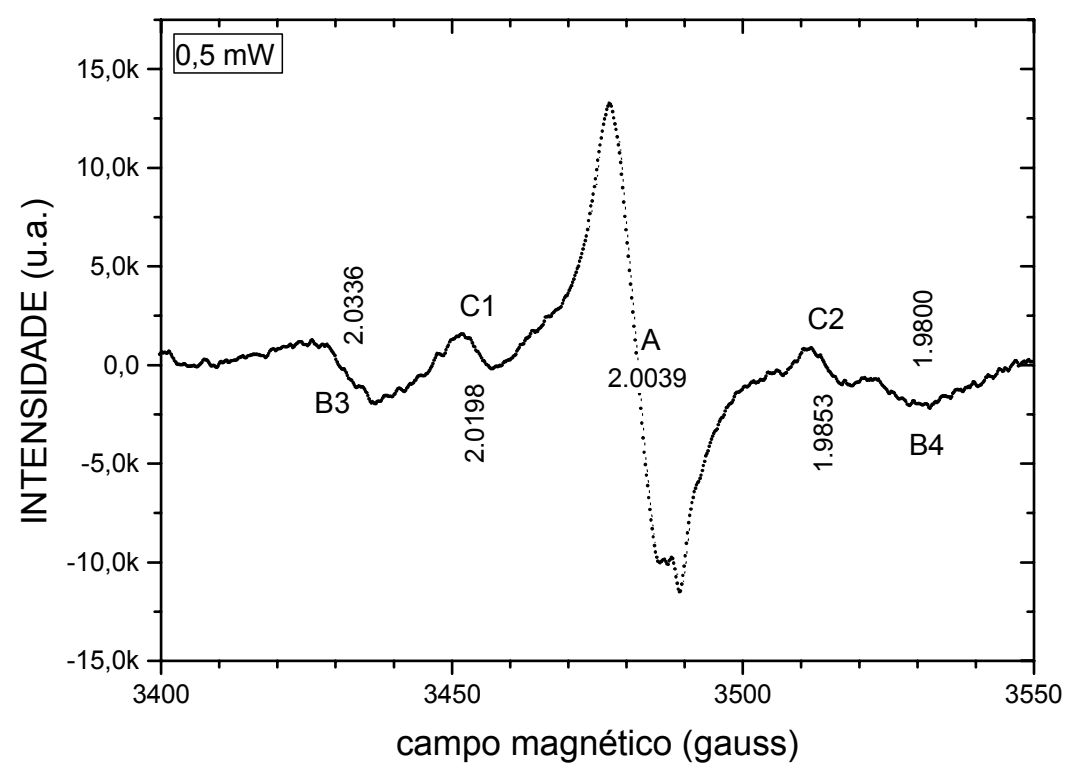

Figura 6. Espectro de RPE de amostra de soja moída e irradiada com $10 \mathrm{kGy}$. Leitura realizada com microondas de $0,5 \mathrm{~mW}$. No intervalo de campo magnético utilizado, notamos os sinais $A, C$ e parte do $B$ (terceiro $e$ quarto picos).

A FIG. 7 apresenta todo o espectro de campo magnético utilizado. O gráfico é resultado de medidas com a amostra BRS155, irradiada com $15 \mathrm{kGy}$, cerca de 24 horas antes da medição. A relativa baixa intensidade do pico central se deve ao valor do ganho utilizado, $2 \times 10^{3}$, da ordem de 20 vezes menor que o valor padronizado neste trabalho. 


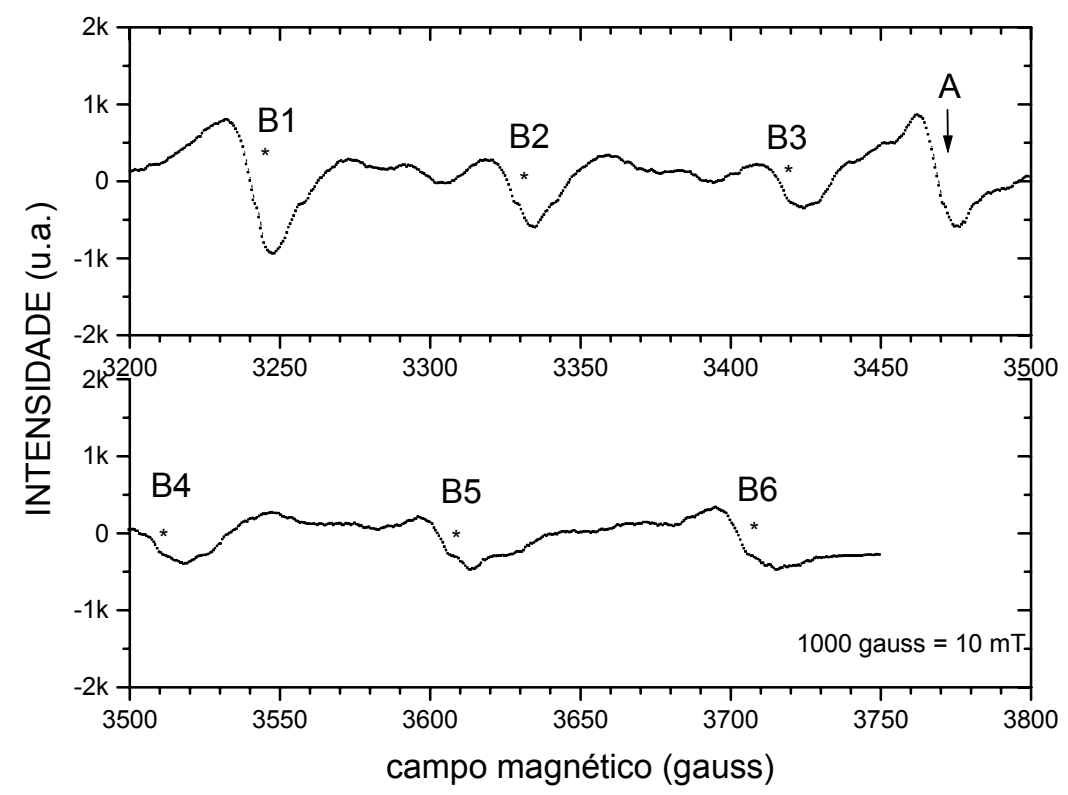

Figura 7. RPE de cultivar BRS155 moída e irradiada com $10 \mathrm{kGy}$. Leitura cerca de 24 horas após a irradiação. A medida foi feita de uma vez, porém o resultado apresentado em dois gráficos, para facilitar o tratamento. Ganho do aparelho de $2 \times 10^{3}$.

O singleto A, na maioria das amostras, foi o pico de maior intensidade, com valor $\mathrm{g}$ por volta de 2,0039. Foi observado tanto em baixas potências como em altas. Em amostras não irradiadas pode-se observar este sinal com intensidade quase nula (FIG. 5). Acredita-se que o sinal, tão frequente em materiais orgânicos (Ingram et al., 1954; Bennett et al., 1955; Robins et al., 1978; Griffiths et al., 1982; Hillman et al., 1983; Robins, 1984; Sales et al., 1985; Ikeya, 1993; Engin et al., 2005), seja devido à radical centrado no carbono.

Yamaoki et al. (2008) encontraram sinais gerados pela irradiação em ervadoce, com g em torno de 2,005. Também, ossos de peixe e boi irradiados com 1$5 \mathrm{kGy}$ apresentam sinais assimétricos com $g_{1}=2,002(1)$ e $g_{2}=1,998(1)$ respectivamente (Atta et al., 2008). 
O sinal $\mathrm{B}$, constituído de seis picos espaçados por aproximadamente 93 gauss (acoplamento hiperfino), foi observado em amostras não irradiadas (FIG. 8 e 10) e em amostras irradiadas (FIG. 7 e 9). Trata-se provavelmente, do sexteto devido a presença de $\mathrm{Mn}^{2+}$, observado com frequência em materiais orgânicos (Ikeya, 1993; Raffi and Agnel, 1990). A intensidade do sinal não parece sofrer grande influência por parte da radiação. Amostras irradiadas ou não, apresentam sinais com intensidades muito próximas (FIG. 9). De fato, as únicas diferenças surgem na região do sinais A e C. Observou-se que o pico de maior $g$ apresentou intensidade sistematicamente maior que os outros cinco. Distorções em picos que deveriam ter a mesma intensidade são comuns e podem estar associadas com algum grau de anisotropia (Parish, 1990).

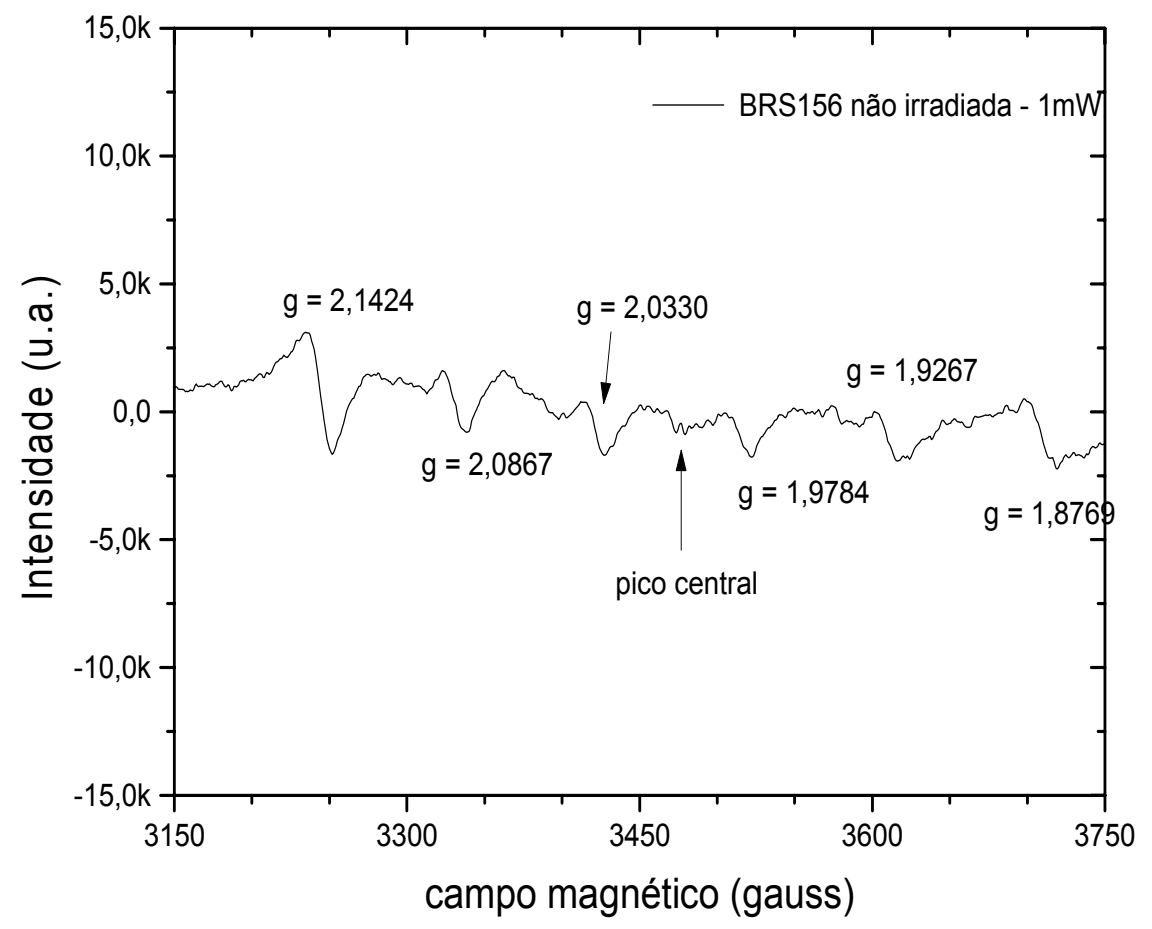

Figura 8 Espectro de RPE de amostra de soja moída e não irradiada. No intervalo de campo magnético utilizado, notamos mais claramente os sinais A e B. A potência empregada foi de $10 \mathrm{~mW}$. 


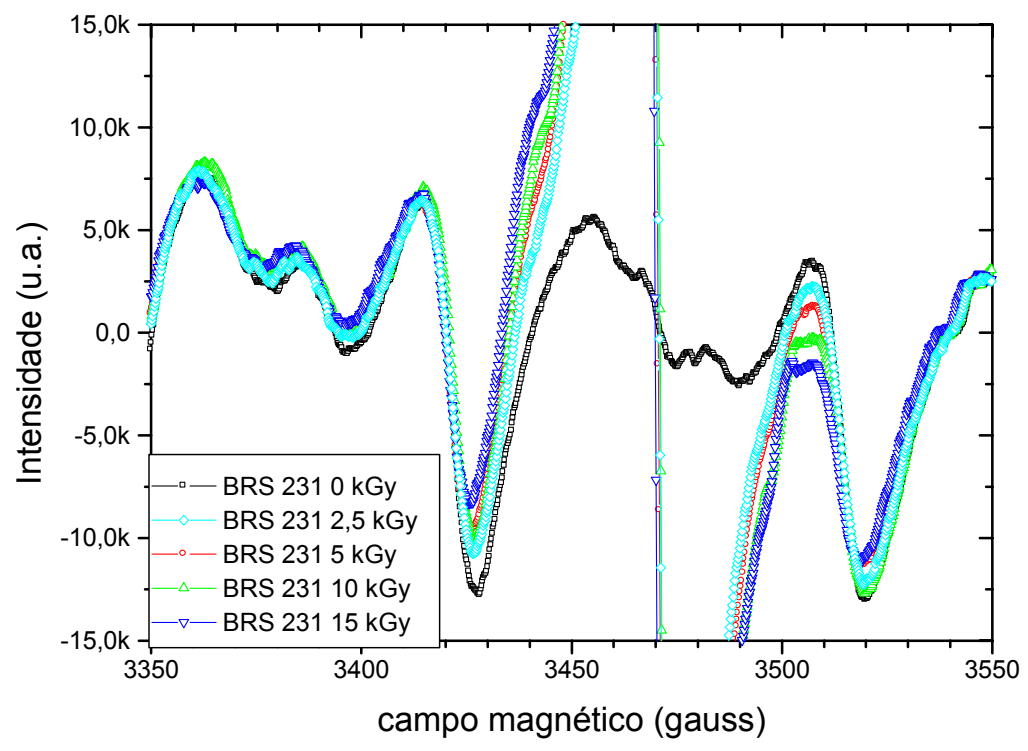

Figura 9. Espectro de RPE de amostra de soja moída não irradiada e irradiada com doses de 2,5, 5,0, 10,0 e 15,0 kGy. O intervalo de campo magnético utilizado e a faixa de intensidades selecionada, enfatizam apenas o sinal B (picos 2, 3 e 4). A potência empregada foi de $10 \mathrm{~mW}$.

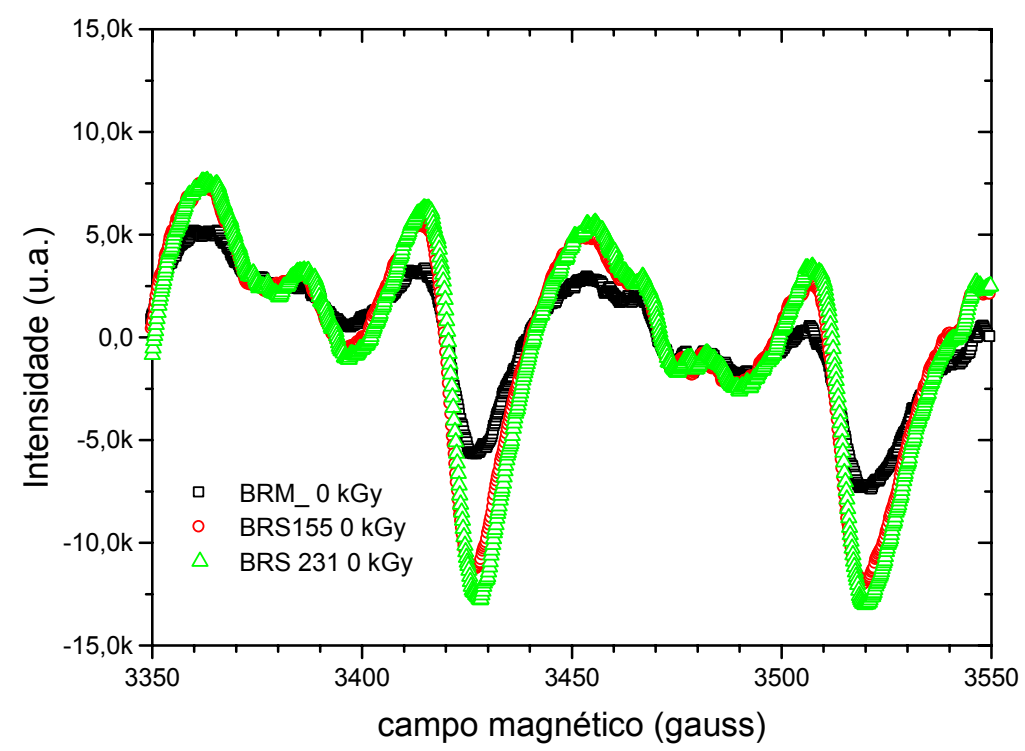

Figura 10. Medidas de RPE para três cultivares moídas e não irradiadas. O intervalo de campo magnético utilizado mostra os picos 2,3 e 4 . A potência empregada foi de $10 \mathrm{~mW}$. 
O sinal $\mathrm{C}$ foi o menor dos três observados. Os valores medidos de $\mathrm{g}$ foram de 2,0198 e 1,9853, com distância de aproximadamente 60 G. Este sinal só pode ser percebido com mais clareza em leituras com potências inferiores a $5 \mathrm{~mW}$. Por sua instabilidade, não foi estudado em detalhes neste trabalho. Na FIG. 8, pode-se visualizar o referido sinal, sobretudo a porção que fica entre o segundo e o terceiro picos do sexteto (da esquerda para a direita), com intensidade quase nula.

Antes da escolha dos parâmetros do equipamento, foram feitas medidas para otimizar as condições de operação do espectrômetro. Após estabelecer os parâmetros de intervalo de campo magnético e tempos de varredura, foi definido o intervalo de potência das microondas. Para potências superiores a $10 \mathrm{~mW}$ (FIG. 11), há uma distorção do sinal $\mathrm{A}$, além de sua saturação.

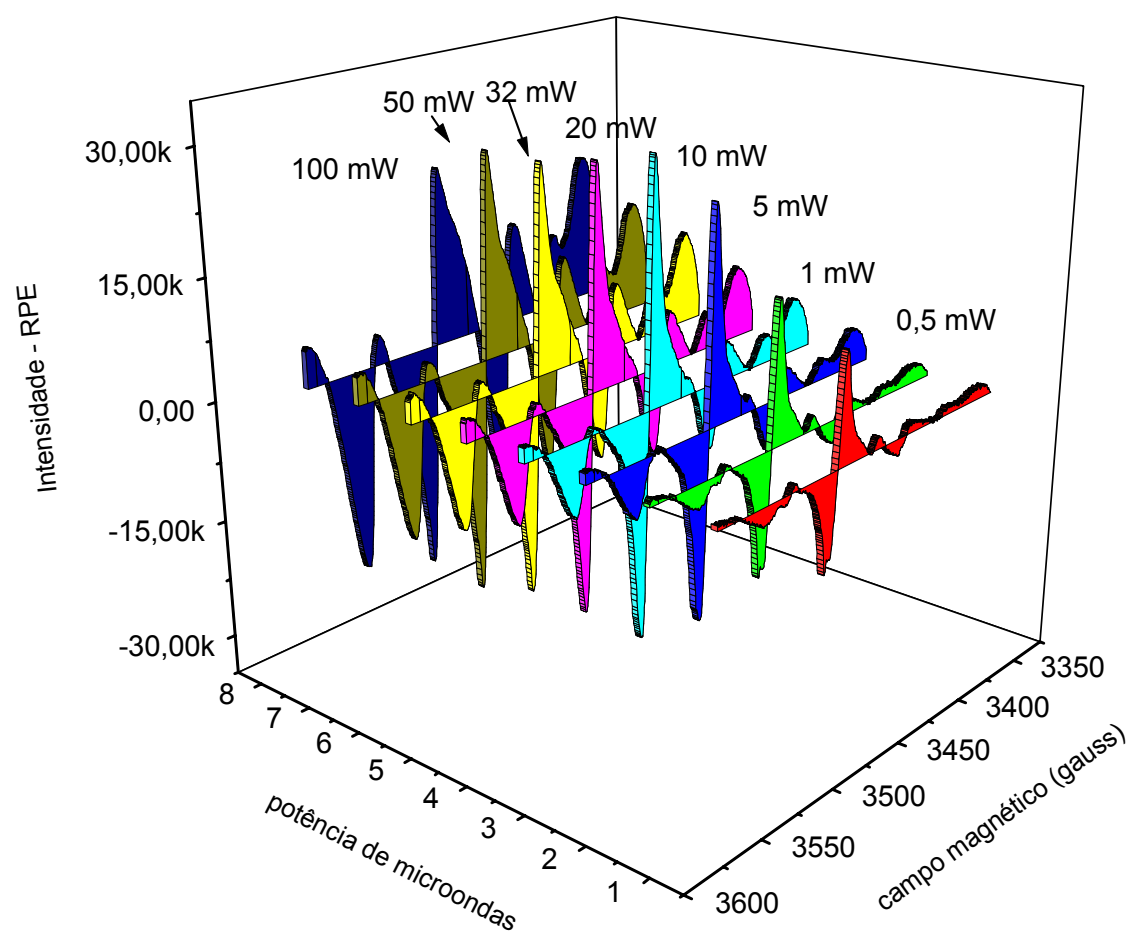

Figura 11. Espectros de RPE da cultivar BRS216, moída e irradiada com $15 \mathrm{kGy}$. Foram feitas oito leituras, com potências de microondas de 1/2, 1 , $5,10,20,32,50$ e $100 \mathrm{~mW}$, aproximadamente. 
Pode-se perceber também uma distorção do sinal B, que aparentemente não está relacionado com o tratamento por radiação ionizante, logo menos útil aos propósitos deste trabalho. Desta forma optou-se por trabalhar sobretudo na faixa de 5 a $10 \mathrm{~mW}$.

\section{IV.2. Detecção por RPE de soja irradiada}

Para avaliar a estabilidade dos sinais de RPE observado nas cultivares, medidas feitas cerca de $24 \mathrm{~h}$ após a irradiação foram repetidas 2, 3 e 7 meses depois. Nessas comparações foi considerado apenas o sinal A, de maior intensidade e reprodutibilidade. Aos dados experimentais foram ajustadas curvas exponenciais do tipo $y=b+a . e^{-k x}$ (FIG.12).

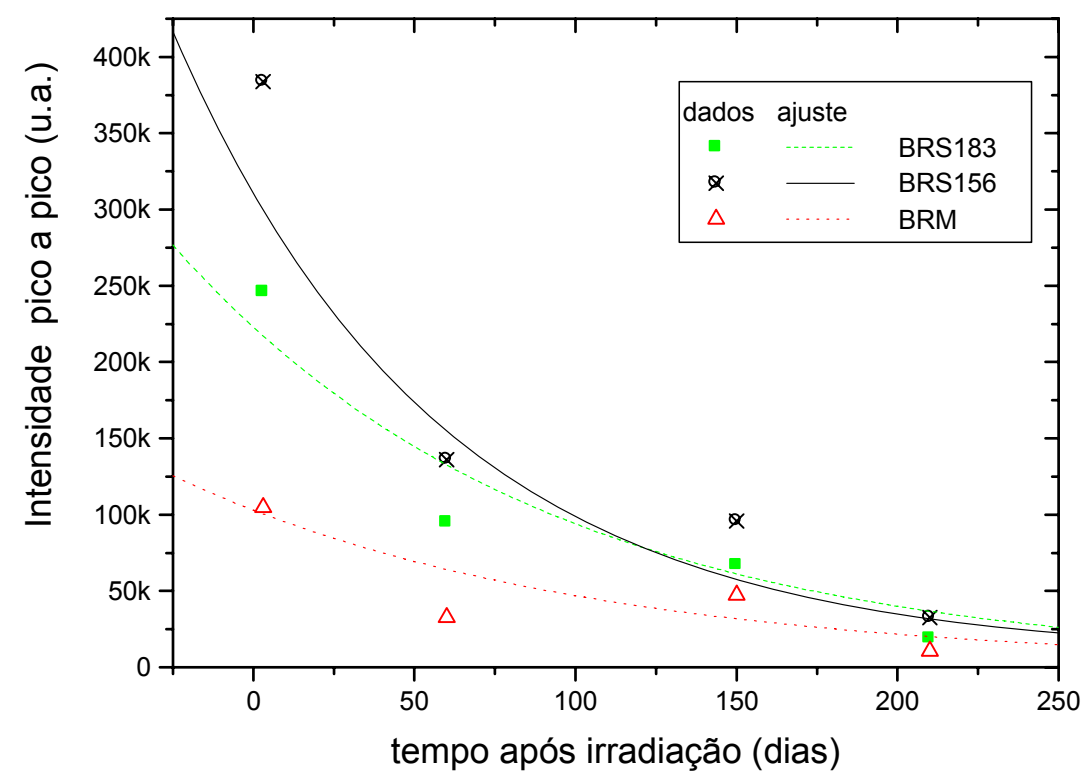

Figura 12. Intensidade do sinal A (distância pico a pico) vs o tempo decorrido entre irradiação de $10 \mathrm{kGy}$ (após moagem) e a leitura. As medidas foram realizadas com três amostras da safra 2004/205. As linhas representam curvas exponenciais ajustadas aos dados. 
Na tabela 6 estão os valores do parâmetros $\mathbf{a}, \mathbf{b}$ e $\mathbf{k}$, medidos através de ajuste com programa Microcal Origin 4.0.

Tabela 6: Parâmetros do ajuste de curvas dos dados experimentais para a intensidade do sinal central em função do tempo decorrido após as irradiações.

\begin{tabular}{cccc}
\hline Cultivar & $\mathbf{a}$ & $\mathbf{b}$ & $\mathbf{k}$ \\
\hline BRM & 101832 & 1165 & $-0,008$ \\
BRS156 & 302967 & 7501 & $-0,012$ \\
BRS183 & 221746 & 1109 & $-0,0087$ \\
\hline
\end{tabular}

A despeito da considerável redução da intensidade com o tempo, o sinal observado é bem superior ao de amostras não irradiadas, onde a distância pico a pico foi sempre inferior a $5 \times 10^{3}$, nas mesmas condições de medida. Desta forma pode ser empregado para verificar se determinada amostra foi ou não irradiada, desde que se possuísse uma amostra de referência não irradiada.

Barros (2002), trabalhando com trigo irradiado com doses de $2 \mathrm{kGy}$, conseguiu através de RPE, identificar quais amostras haviam sido irradiadas em até 3 semanas após a irradiação.

Amostras irradiadas antes do processo de moagem produziram picos de ressonância bem inferiores àqueles em que a amostra foi primeiramente moída e posteriormente irradiada. Na FIG. 13 são comparadas as intensidades dos picos centrais para amostras irradiadas antes de moídas (BRS155 e BRS231) com amostras cuja moagem ocorreu antes do tratamento com ${ }^{60} \mathrm{Co}$ (BRS184 e BRS212). Ambas medidas foram realizadas cerca de $24 \mathrm{~h}$ após a irradiação, com potência de microondas de $10 \mathrm{~mW}$. O sinal maior das amostras cuja moagem se deu antes da irradiação pode ser atribuída a uma maior área de contato quando a soja está moída, favorecendo assim a formação de radicais livres induzidos pela radiação. 


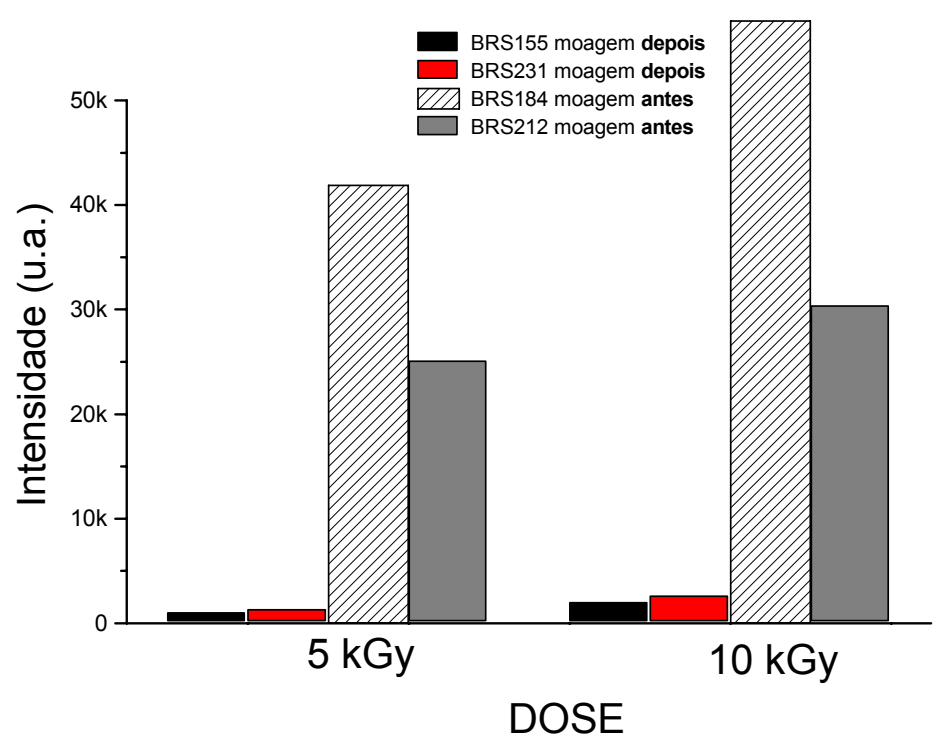

Figura 13. Intensidade do sinal A em amostras cuja moagem ocorreu antes ou após a irradiação, com doses de 5 ou 10 kGy.

Dentro do intervalo de doses utilizado, a intensidade do sinal A (pico a pico) aumenta com o incremento da dose (FIG. 14).

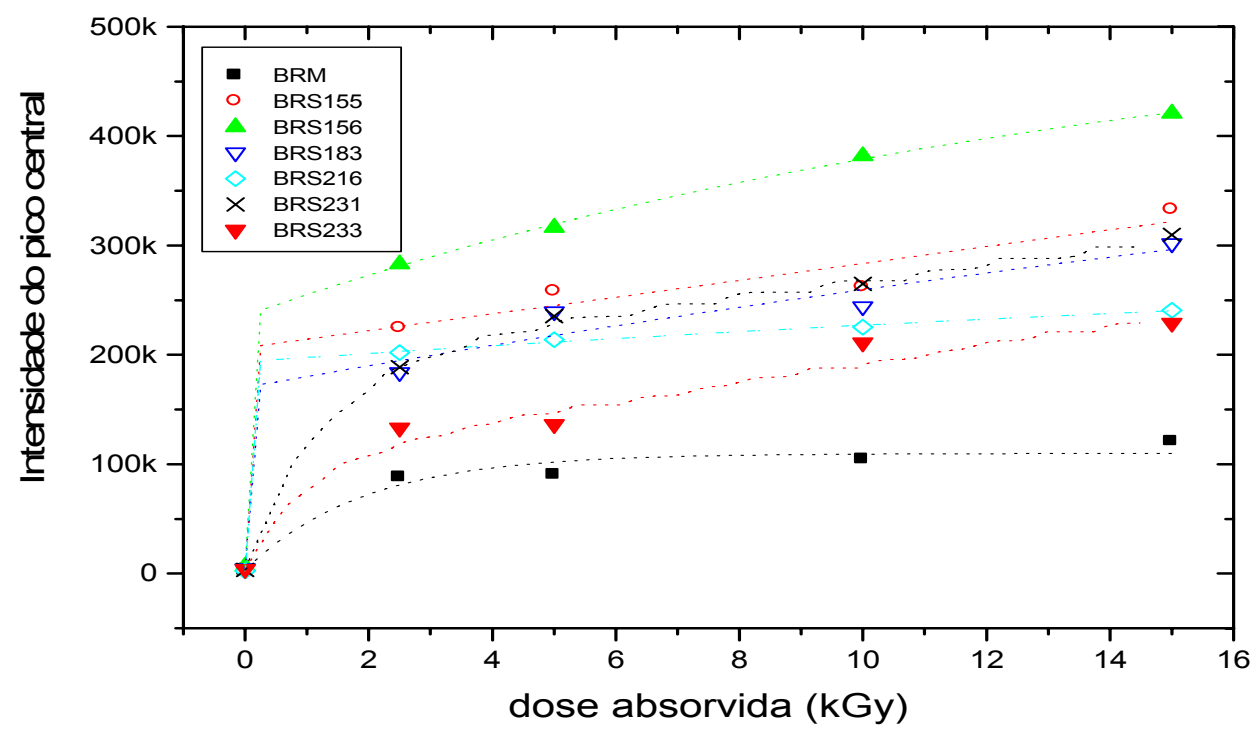

Figura 14. Intensidade do sinal de RPE vs dose absorvida para amostras de soja (safra 2004/05). Curvas ajustadas aos pontos experimentais. Medidas realizadas cerca de 4 dias após a irradiação. 
Os pontos experimentais dos gráficos da FIG. 14 foram ajustados a exponenciais do tipo:

$$
\mathrm{y}=\mathrm{y}_{\mathrm{o}}+\mathrm{a}\left(1-\exp \left(\frac{-\mathrm{x}}{\mathrm{t}_{1}}\right)\right)+\mathrm{b}\left(1-\exp \left(\frac{-\mathrm{x}}{\mathrm{t}_{2}}\right)\right)
$$

Os resultados dos valores dos parâmetros foram obtidos com o programa Microcal Origin 4.0 e estão na TAB. 7.

Tabela 7: Parâmetros do ajuste dos dados dos gráficos da FIG 14 a curvas exponenciais.

\begin{tabular}{|c|c|c|c|c|c|}
\hline Cultivar & $y_{0}$ & a & b & $t_{1}$ & $t_{2}$ \\
\hline BRM 52 & 3261 & $-2,06$ E9 & 2,06 E9 & 1,91 & 1,91 \\
\hline BRS 155 & 3980 & $5,05 \mathrm{E} 13$ & 2,03 E5 & 6,57 E9 & $1,5 \mathrm{E}-2$ \\
\hline BRS 156 & 6425 & 2,91 E5 & 2,29 E5 & 14,80 & $1,5 \mathrm{E}-2$ \\
\hline BRS 183 & 4378 & 69,62 & 1,66 E5 & 39,32 & $2,0 \mathrm{E}-3$ \\
\hline BRS 216 & 2276 & 1,26 E5 & 1,92 E5 & 32,50 & $3,0 \mathrm{E}-2$ \\
\hline BRS 231 & 3274 & $9,21 \mathrm{E} 19$ & 1,82 E5 & 1,29 E16 & 1,28 \\
\hline BRS 233 & 3497 & 7,48 E19 & $8,58 \mathrm{E} 15$ & $1,01 \mathrm{E} 5$ & $9,8 \mathrm{E}-1$ \\
\hline
\end{tabular}

Leveque et al. (2008) descrevem que a RPE pode detectar radicais livres de maneira não invasiva in vivo e in vitro, com grande sensibilidade em produtos alimentícios. Mencionam também que radicais livres contidos em alimentos dão sinais de RPE característicos compatíveis com a obtenção de imagens de alta qualidade. Lee et al. (2008) também encontraram aumento do sinal de RPE com o aumento da dose em sementes de gergelim, o que pode ser utilizado para identificar amostras irradiadas. Prasuna et al. (2008) também consideram que a análise por RPE é uma ferramenta eficiente na identificação de produtos vegetais irradiados. Em todas as amostras vegetais foi observada a presença de radical livre correspondente à celulose. Quase todas as amostras desse estudo exibiam íons $\mathrm{Mn}$ em diferentes estados de oxidação.

Sanyal et al. (2008) descrevem a identificação de castanhas de caju irradiadas utilizando espectroscopia por RPE. Eles irradiaram as castanhas com doses de 0,25; 
0,50; 0,75 e 1kGy. Esses autores obtiveram um tripleto fraco de vida-média curta ( $\mathrm{g}=$ 2,004 e acoplamento hiperfino de 30 gauss), além de sinal anisotrópico ( $\mathrm{g} \perp=2,0069$ e $\mathrm{g}_{\|}=2,000$ ) produzidos imediatamente após irradiação. Esses sinais foram atribuídos àqueles radicais da celulose e $\mathrm{CO}_{2}$. Entretanto, as amostras irradiadas mostraram um aumento dependente da dose da linha central $(g=2,0045 \pm 0,0002)$. A natureza dos radicais livres formados durante processamentos convencionais, tais como, tratamento térmico, foram investigados e mostraram um aumento da intensidade da linha central $(g=2,0045)$ similar àquela produzida pela irradiação.

Amic et al. (2003) sugerem que haveria uma relação entre a estrutura dos flavonóides e sua capacidade de neutralizar radicais livres. Kwon et al. (2002), consideram que para determinar com segurança se um produto alimentício foi ou não irradiado é necessária a aplicação de vários métodos alternativos. 
IV. 3. Correlação entre as concentrações totais ou parciais de isoflavonas com a intensidade do sinal

Pode-se observar certa ordem nas intensidades do pico A, para diferentes doses empregadas, quando comparadas as diferentes cultivares. Essa hierarquia pode ser observada nas FIG.15 e 16, para ambas as safras, e na FIG. 17, para a safra 2004/05. As diferenças de intensidade para ambas as safras (já descontados os números de leituras, 3 e 5) podem ter sido provocadas por diferenças no intervalo entre irradiação e medida (4 e 10 dias), e ao tempo de estocagem do material ${ }^{4}$.

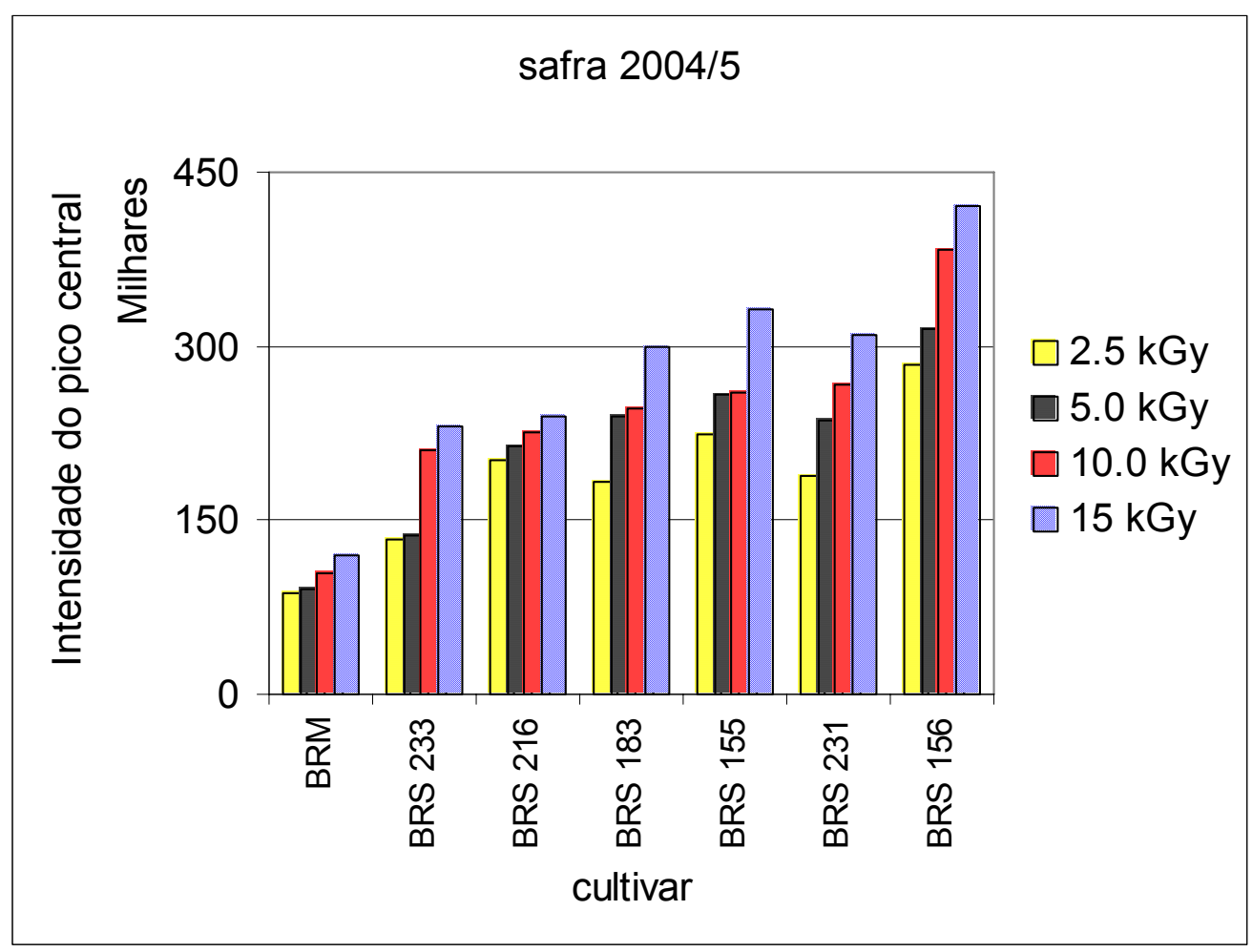

Figura 15. Intensidade do pico central das cultivares da safra 2004/05, irradiadas. As medidas foram feitas 4 dias após a irradiação. As amostras foram moídas antes de serem irradiadas. As intensidades são fruto de 5 leituras acumuladas.

\footnotetext{
${ }^{4}$ As medidas com a safra 2002/03 foram realizadas em abril/2004; com a safra 2004/05, em setembro/2005. Como a colheita ocorre entre o fim de um ano e início do outro, estima-se que o intervalo entre a colheita e as medidas de RPE sejam da ordem de 9 e 16 meses, respectivamente.
} 


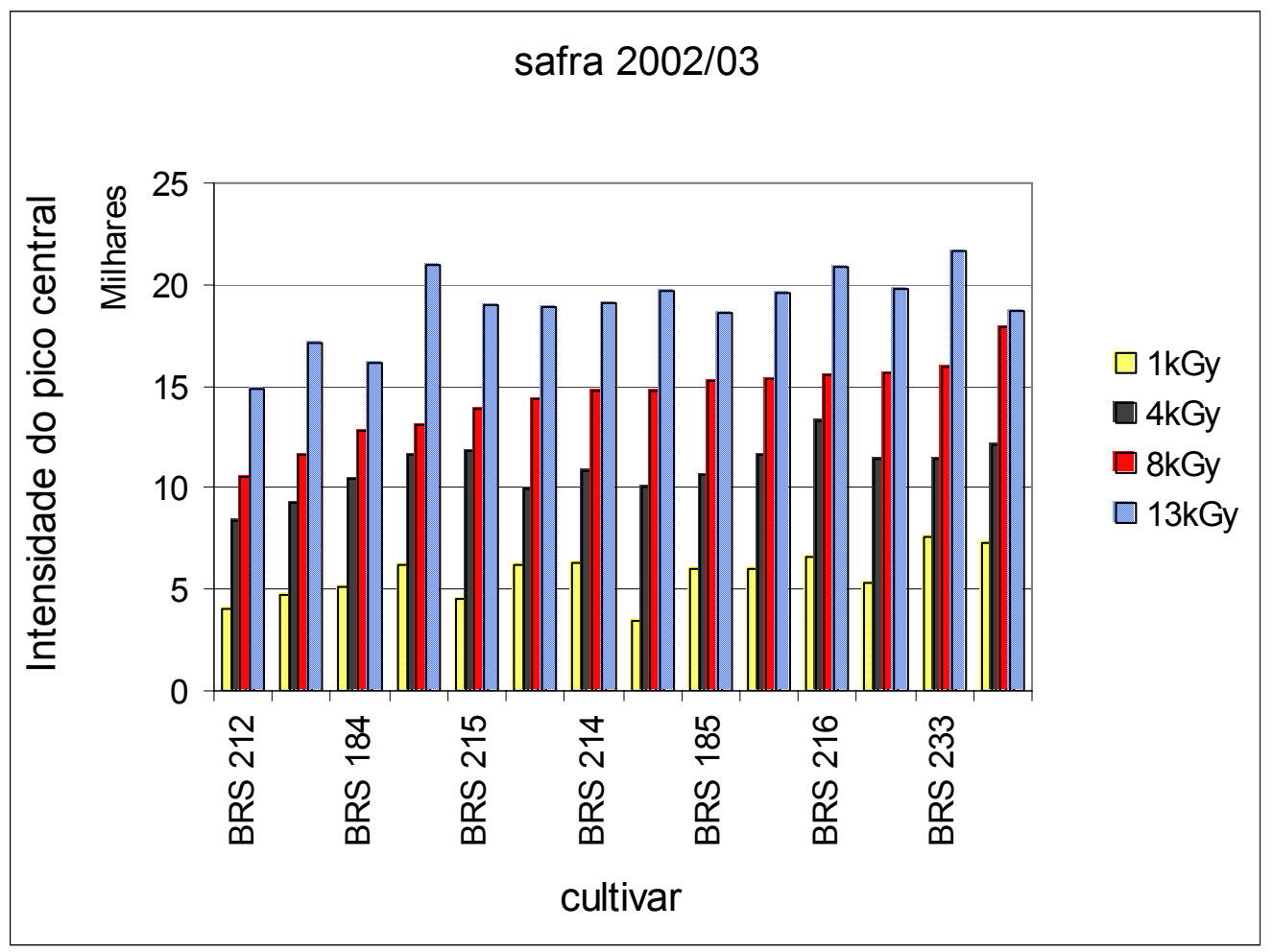

Figura 16. Intensidade do pico central das cultivares da safra 2002/03, irradiadas. As medidas foram feitas 10 dias após a irradiação. As amostras foram moídas antes de serem irradiadas. As intensidades são fruto de 3 leituras acumuladas. 


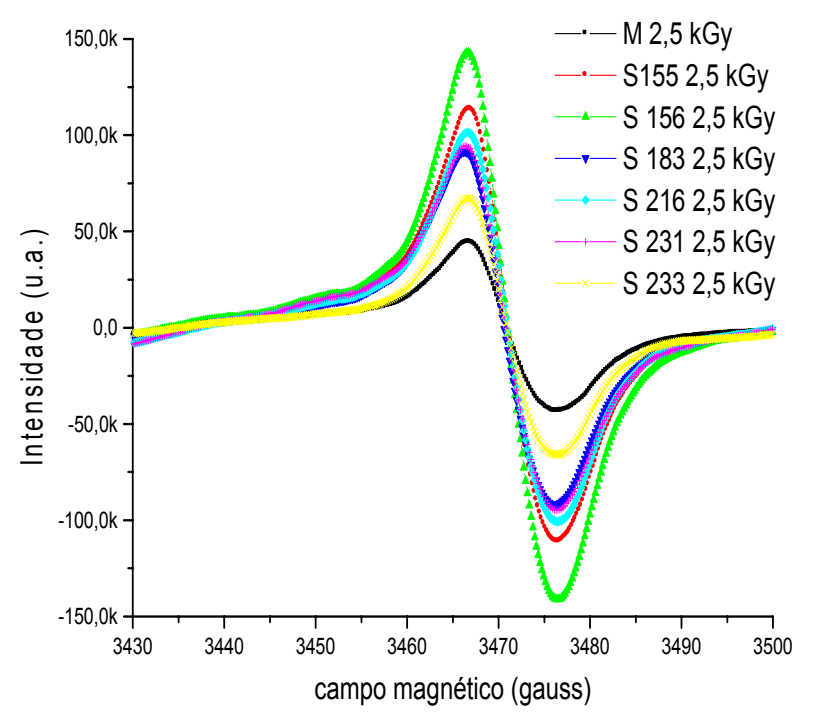

a

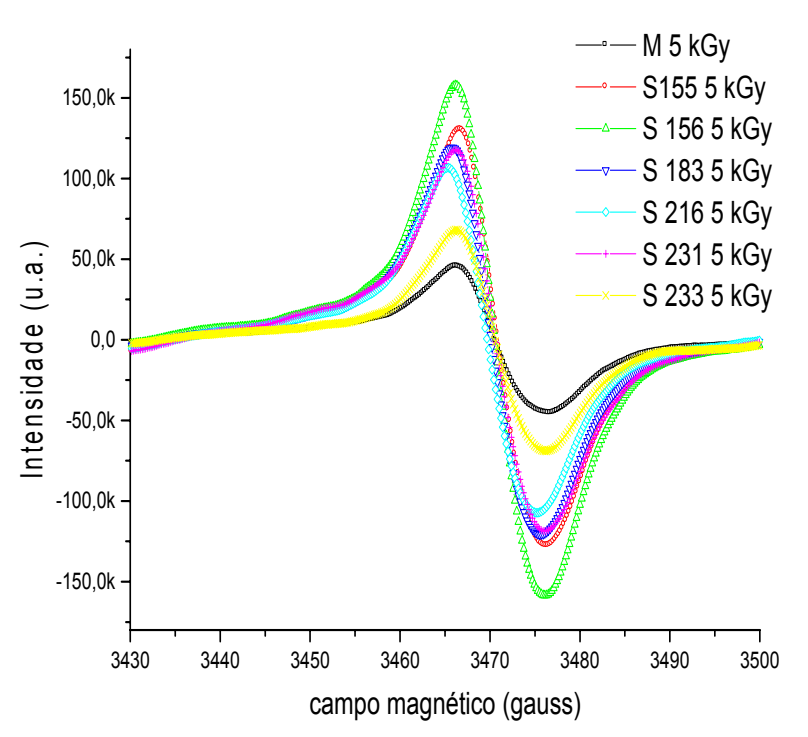

b

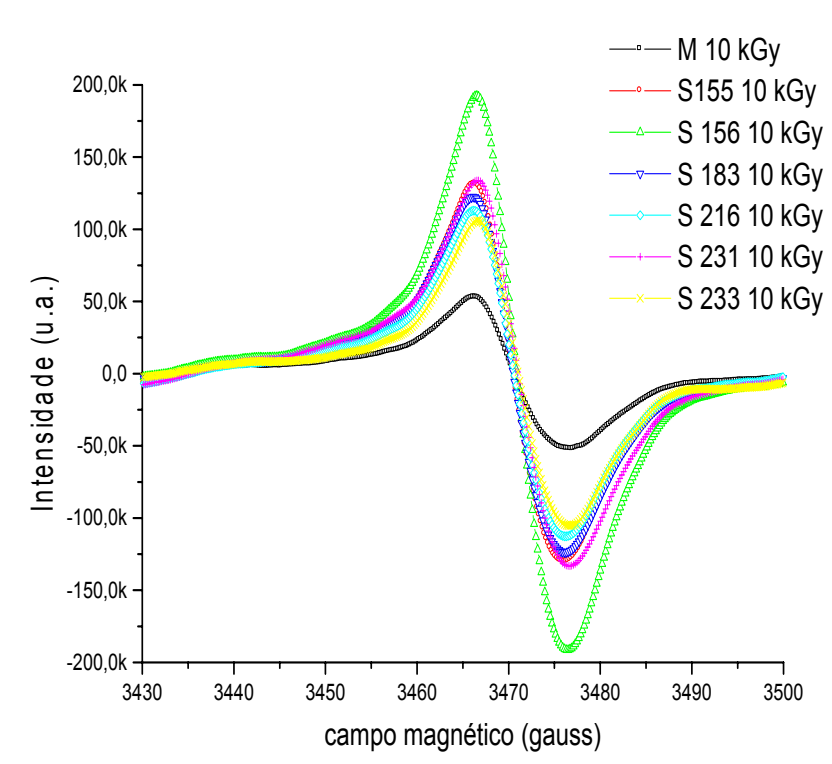

C

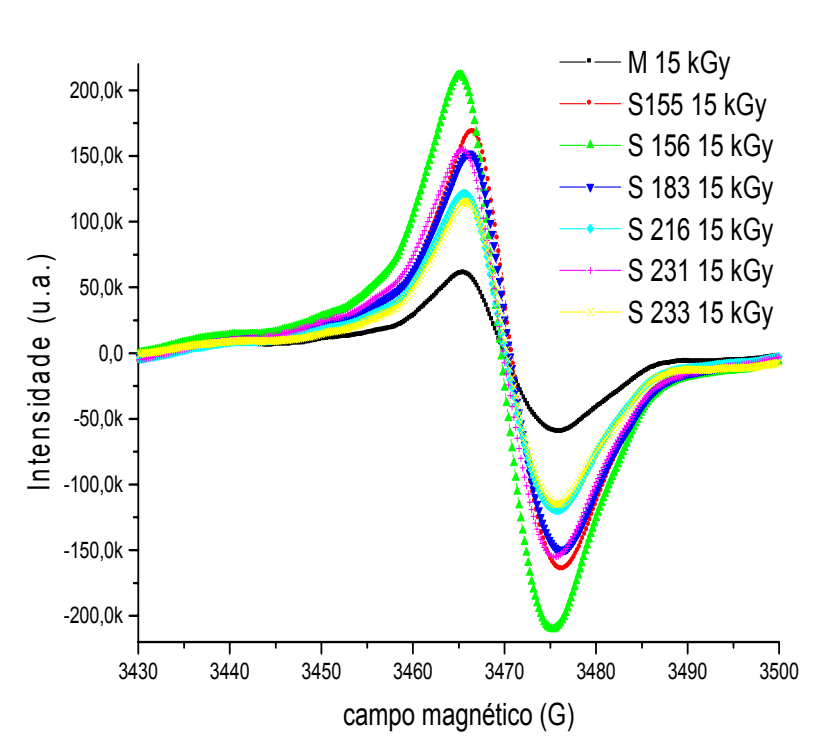

d

Figura 17. Intensidade do sinal RPE para cultivares da safra 2004/2005, irradiadas com doses: (a) 2,5 kGy, (b) 5,0 kGy, (c) 10,0 kGy e (d) 15,0 kGy.

Com base nessas observações, foram calculados os índices de correlação linear (APÊNDICE I) entre a intensidade dos picos (sinal A) e o conteúdo de 
isoflavonas (totais e parciais) em cada cultivar (TAB. 8 e 9). Desta forma pode-se verificar se há uma influência das isoflavonas nos efeitos gerados pela radiação.

Tabela 8: Correlação linear entre o teor de isoflavona (total e parcial) das 07 cultivares da safra 2004/05 e a intensidade do sinal A (pico a pico).

\begin{tabular}{cccc|ccc|c|c|c}
\cline { 2 - 7 } $\begin{array}{c}\text { dose } \\
\text { (kGy) }\end{array}$ & \multicolumn{3}{c|}{ beta-glucosídeo } & \multicolumn{3}{c|}{ malonil-glucosídeo } & \multicolumn{2}{c|}{ aglicona } & \multirow{2}{*}{ total } \\
\cline { 2 - 7 } & daidzina & glicitina & genistina & daidzina & glicitina & genistina & daidzeína & genisteína & \\
\hline 2,5 & $-0,38$ & $-0,76$ & 0,49 & 0,41 & 0,51 & $-0,16$ & $-0,22$ & $-0,32$ & $-0,34$ \\
5,0 & $-0,46$ & $-0,84$ & 0,37 & 0,48 & 0,51 & $-0,26$ & $-0,35$ & $-0,44$ & $-0,48$ \\
10,0 & $-0,48$ & $-0,71$ & 0,47 & 0,40 & 0,65 & 0,04 & $-0,34$ & $-0,44$ & $-0,27$ \\
15,0 & $-0,43$ & $-0,78$ & 0,48 & 0,49 & 0,57 & $-0,05$ & $-0,33$ & $-0,43$ & $-0,32$ \\
\hline
\end{tabular}

Tabela 9: Correlação linear entre o teor de isoflavona (total e parcial) das 14 cultivares da safra 2002/03 e a intensidade do sinal A (pico a pico).

\begin{tabular}{|c|c|c|c|c|c|c|c|c|c|c|c|c|}
\hline \multirow{2}{*}{$\begin{array}{l}\text { dose } \\
\text { (kGy) }\end{array}$} & \multicolumn{3}{|c|}{ beta-glucosídeo } & \multicolumn{3}{|c|}{ malonil-glucosídeo } & \multicolumn{2}{|c|}{$\begin{array}{c}\text { acetil- } \\
\text { glucosídeo }\end{array}$} & \multicolumn{3}{|c|}{ aglicona } & \multirow{2}{*}{ total } \\
\hline & $\begin{array}{l}\text { Daidzi- } \\
\text { na }\end{array}$ & glicitina & $\begin{array}{c}\text { genisti- } \\
\text { na }\end{array}$ & $\begin{array}{c}\text { daidzi- } \\
\text { na }\end{array}$ & glicitina & $\begin{array}{c}\text { genisti- } \\
\text { na }\end{array}$ & $\begin{array}{c}\text { daidzi- } \\
\text { na }\end{array}$ & $\begin{array}{c}\text { genisti- } \\
\text { na }\end{array}$ & $\begin{array}{c}\text { daidzeí- } \\
\text { na }\end{array}$ & $\begin{array}{c}\text { glicite- } \\
\text { ina }\end{array}$ & $\begin{array}{c}\text { genisteí } \\
\text {-na }\end{array}$ & \\
\hline 1,0 & $-0,57$ & $-0,13$ & $-0,46$ & $-0,36$ & $-0,35$ & $-0,34$ & $-0,57$ & $-0,67$ & $-0,57$ & $-0,74$ & $-0,76$ & $-0,53$ \\
\hline 4,0 & $-0,27$ & 0,11 & $-0,40$ & $-0,12$ & $-0,29$ & $-0,40$ & $-0,53$ & $-0,44$ & $-0,27$ & $-0,37$ & $-0,40$ & $-0,34$ \\
\hline 8,0 & $-0,32$ & 0,05 & $-0,42$ & $-0,38$ & $-0,50$ & $-0,55$ & $-0,59$ & $-0,59$ & $-0,32$ & $-0,38$ & $-0,38$ & $-0,45$ \\
\hline 13,0 & 0,08 & 0,53 & $-0,07$ & 0,13 & 0,14 & $-0,20$ & $-0,16$ & $-0,39$ & 0,08 & $-0,16$ & $-0,23$ & 0,00 \\
\hline
\end{tabular}

Para os resultados da safra 2004/05, dentro de um nível de significância de $5 \%$, só houve correlação entre o sinal de RPE e os teores de glicitina (forma $\beta$ glicosídica).

Na safra 2002/03, os índices de correlação linear calculados dentro do mesmo nível de significância, levam a correlações para 11 dos 48 cálculos de r, a maior parte também negativa. Destacam-se em particular, os resultados para a forma acetil-daidzina, onde é verificada a correlação negativa para 3 das 4 doses empregadas, indicando mais uma vez que teores elevados de certos tipos de isoflavonas induziriam um sinal de RPE menor. Cabe ressaltar que a forma acetil não havia sido detectada nas análises da safra 2004/05. 
Como mencionado anteriormente, ocorrem variações expressivas nos teores de isoflavonas em virtude de diferenças em condições climáticas e de plantio (Ávila et al., 2007; Carrão-Pannizi, 1995; 1996; 1998) ou no próprio processo de extração, acarretando em interconversões de um tipo a outro (Wang e Murphy, 1994).

Barbosa et al (2006) encontraram uma alta correlação, acima de 0,70, entre a atividade antioxidante e o teor de flavonóides e fenólicos totais em soja. Eles também concluíram que o conteúdo total e tipo de isoflavonas e o teor de fenólicos de produtos de soja dependem do processamento e que a capacidade antioxidante desses produtos varia significativamente. Outros autores obtiveram, para produtos ricos em polifenóis, uma correlação linear entre atividade antioxidante e concentração de flavonóides (Stasko et al, 2008),

\section{IV.4. Efeito da temperatura no sinal de RPE}

Embora o objetivo deste trabalho tenha sido o estudo de amostras à temperatura ambiente, foram feitas algumas medidas em temperaturas inferiores para que se pudesse entender melhor o comportamento do sinal. A amostra BRS216, moída e irradiada com $5 \mathrm{kGy}$ à temperatura de gelo seco $\left(\mathrm{CO}_{2}\right.$ a aproximadamente $-78,5^{\circ} \mathrm{C}$ ) foi colocada em um tubo de quartzo que estava envolto por um recipiente contendo nitrogênio líquido. Após a leitura por RPE, o nitrogênio líquido foi retirado e foram refeitas as medições 3, 6 e 20 minutos depois da retirada do recipiente. Como houve variação no sinal de RPE, a amostra foi recolocada no recipiente de nitrogênio líquido e a medida refeita (FIG. 18). 


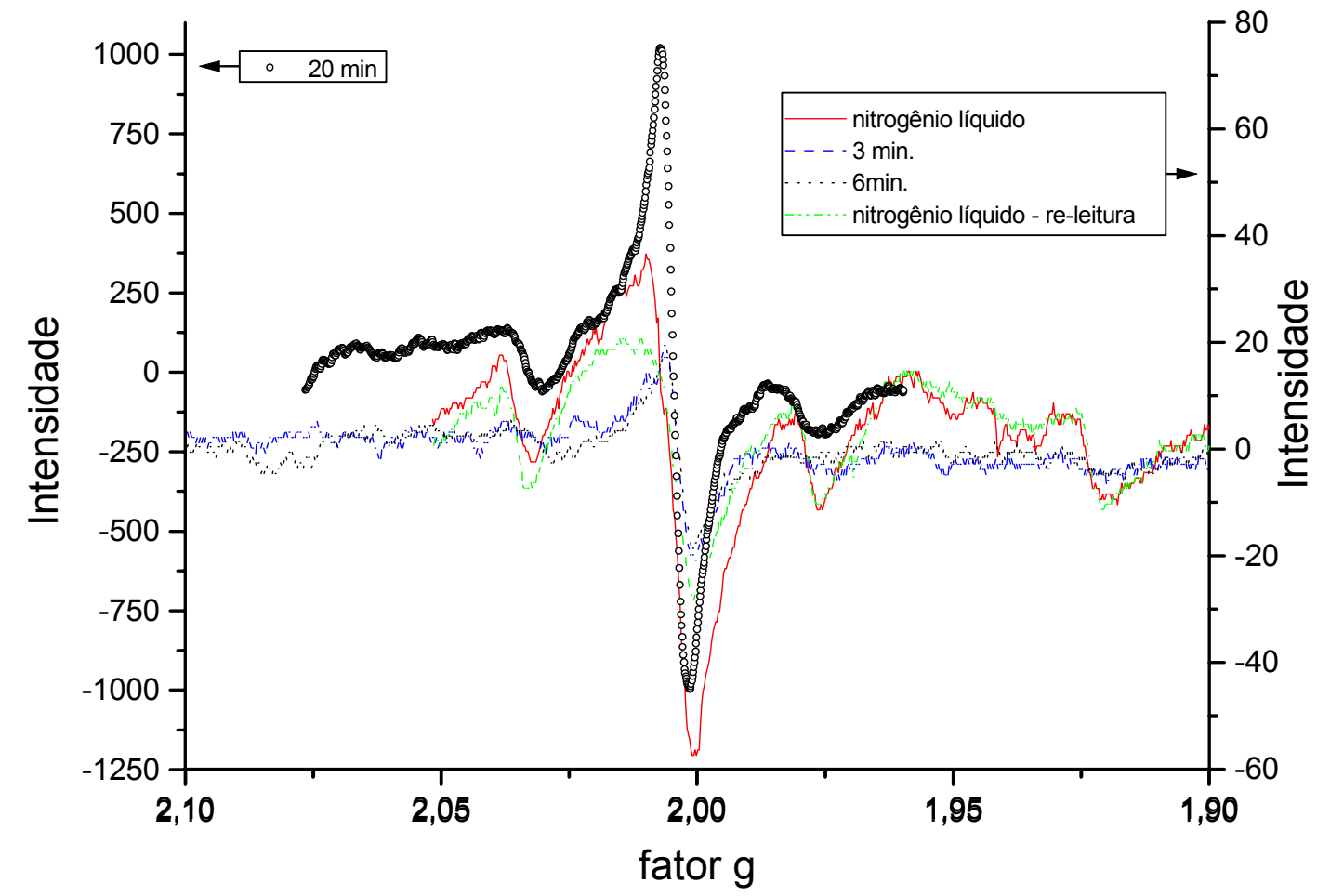

Figura 18. RPE da amostra BRS216, irradiada com $5 \mathrm{kGy}$ à temperatura de gelo seco: (1) medida à temperatura de nitrogênio líquido; (2) medida após 3 min de exposição da amostra à temperatura ambiente; (3) após 6 min de exposição; (4) releitura.

Por trepidar um pouco, a leitura resultou em um sinal de RPE menos estável do que em condições de leitura à temperatura ambiente. Pelo perfil das curvas, não se nota uma mudança significativa entre os resultados à baixa temperatura e à temperatura ambiente. $\mathrm{O}$ fato de a irradiação ter sido realizada à baixa temperatura também não produz alterações significativas nas medidas, quando comparadas com os resultados vistos até o presente momento. Nota-se o sinal A um pouco mais alargado em medidas à baixa temperatura, o que poderia indicar uma maior interação dos elétrons envolvidos na ressonância com outros campos. 
Como os resultados à baixa temperatura, antes e depois da amostra ter sido submetida a temperatura ambiente, são semelhantes, pode-se dizer que não há, na faixa de temperatura analisada $\left(-78\right.$ a $\left.28^{\circ} \mathrm{C}\right)$, formação de sinal diferente dos observados apenas em temperatura ambiente. A diferença de intensidade entre as curvas da FIG. 17 deve-se em parte a uma absorção do sinal pelo recipiente com nitrogênio.

Os valores de ganho e número de leituras, apesar de não serem iguais, foi padronizado para que se pudesse compará-las em uma mesma escala. Como as condições de ressonância do porta-amostra variam com a temperatura, a frequência de microondas também muda. Desta forma optou-se por expor os resultados em função do fator g, e não do campo magnético.

IV.5. Sinal de RPE das diversas partes do grão de soja

Com o objetivo de distinguir a contribuição de cada uma das partes do grão de soja para a formação do sinal de RPE, os grãos de três cultivares representativas da safra 2004/05 foram divididos em quatro porções (Oliveira \& Mastro, 2004): casca, hilo, cotilédones e hipocótilo (FIG. 19, 20, 21 e 22). A escolha destas três particulares amostras levou em conta a quantidade total de isoflavonas: BRS231, a de menor teor; BRM, a de maior teor, e BRS155, com concentração intermediária. 


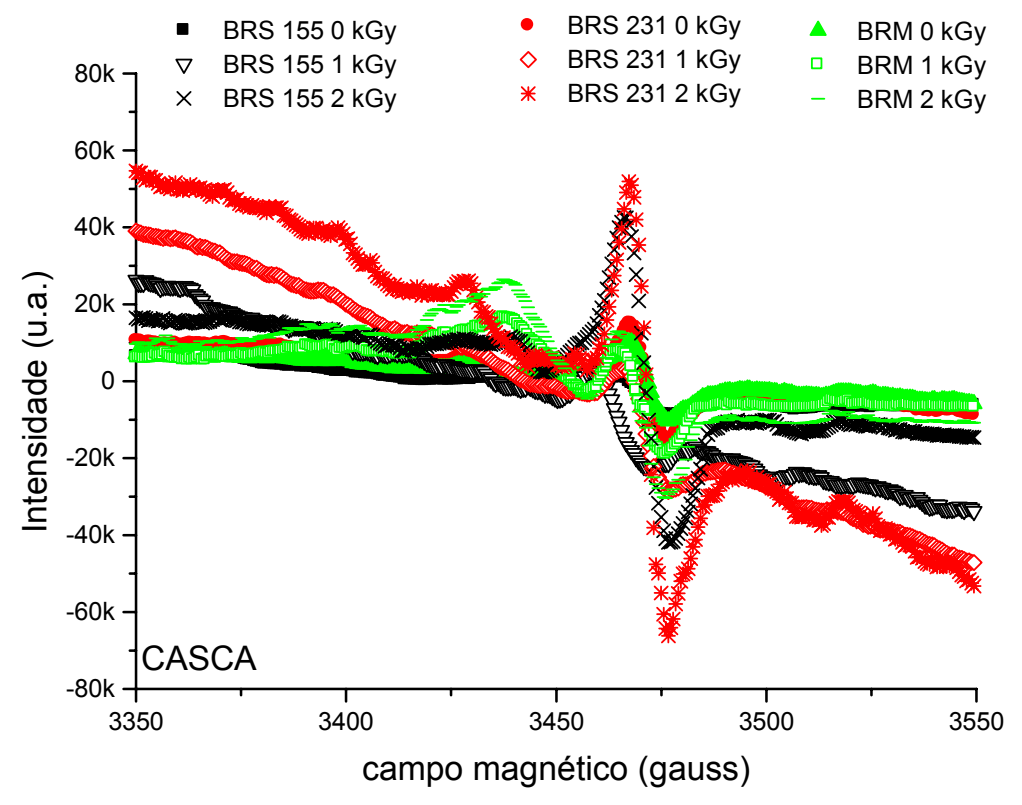

Figura 19. RPE da casca de três cultivares: não irradiada e irradiada com doses de 1 e 2 kGy.

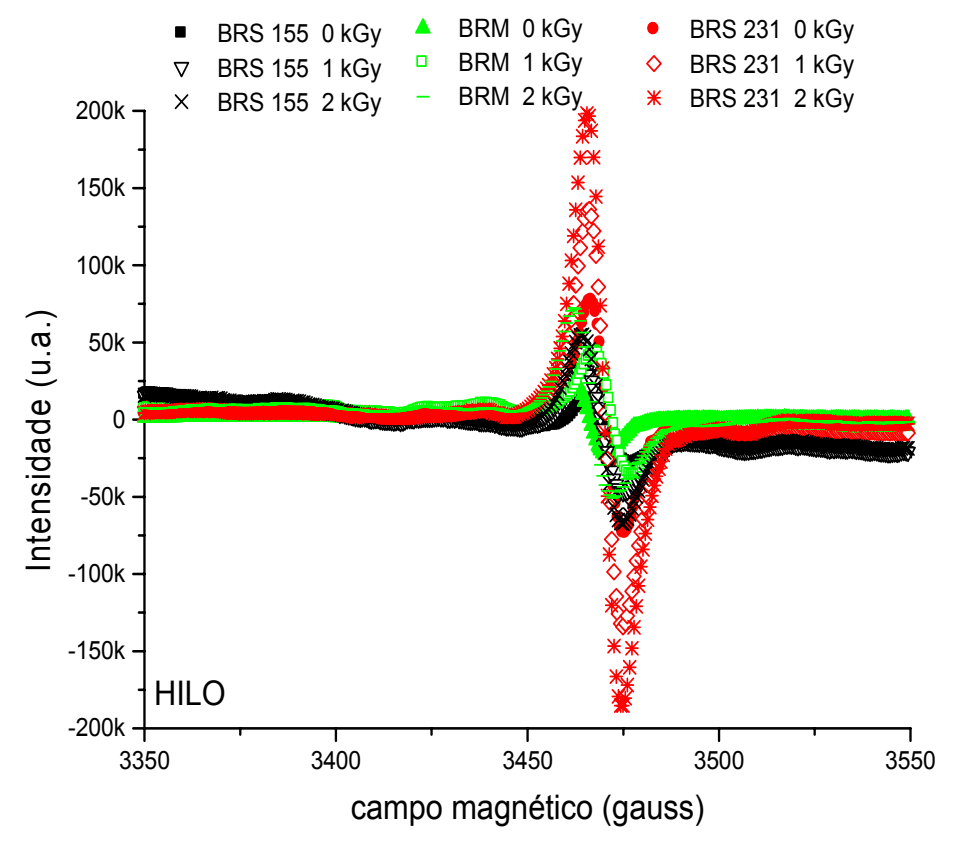

Figura 20. RPE em hilo de três cultivares: não irradiado e irradiado com doses de 1 e 2 kGy. 


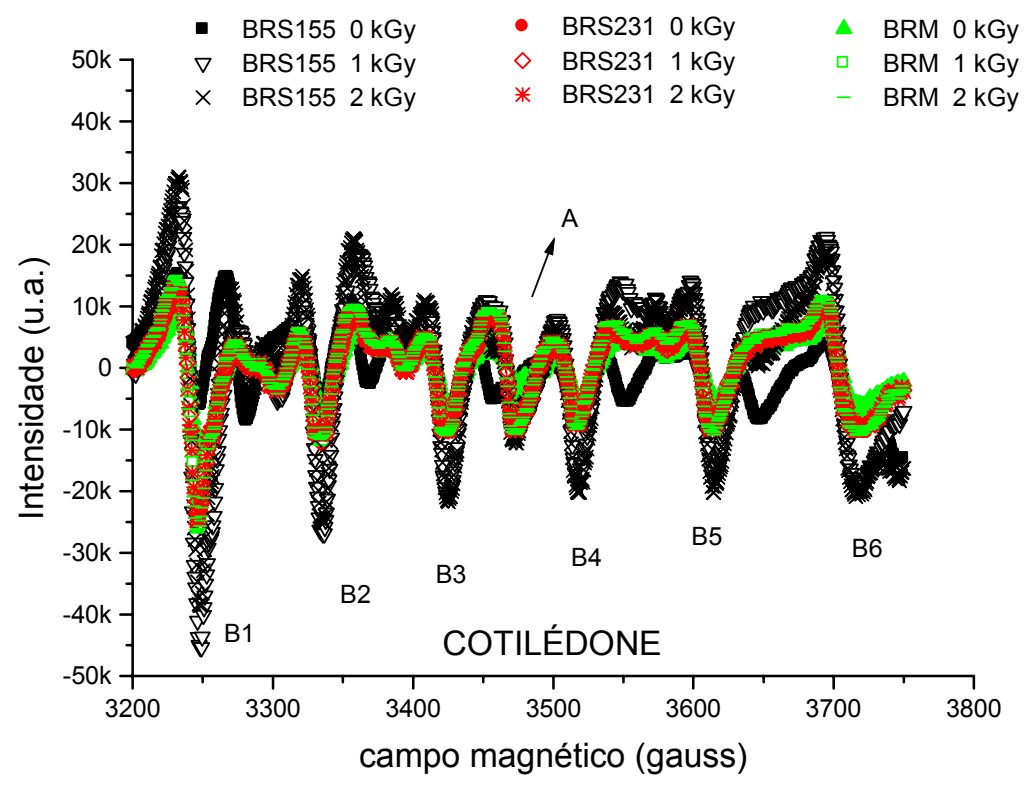

Figura 21. RPE em cotilédones moídos de três cultivares: não irradiada e irradiada com doses de 1 e 2 kGy.

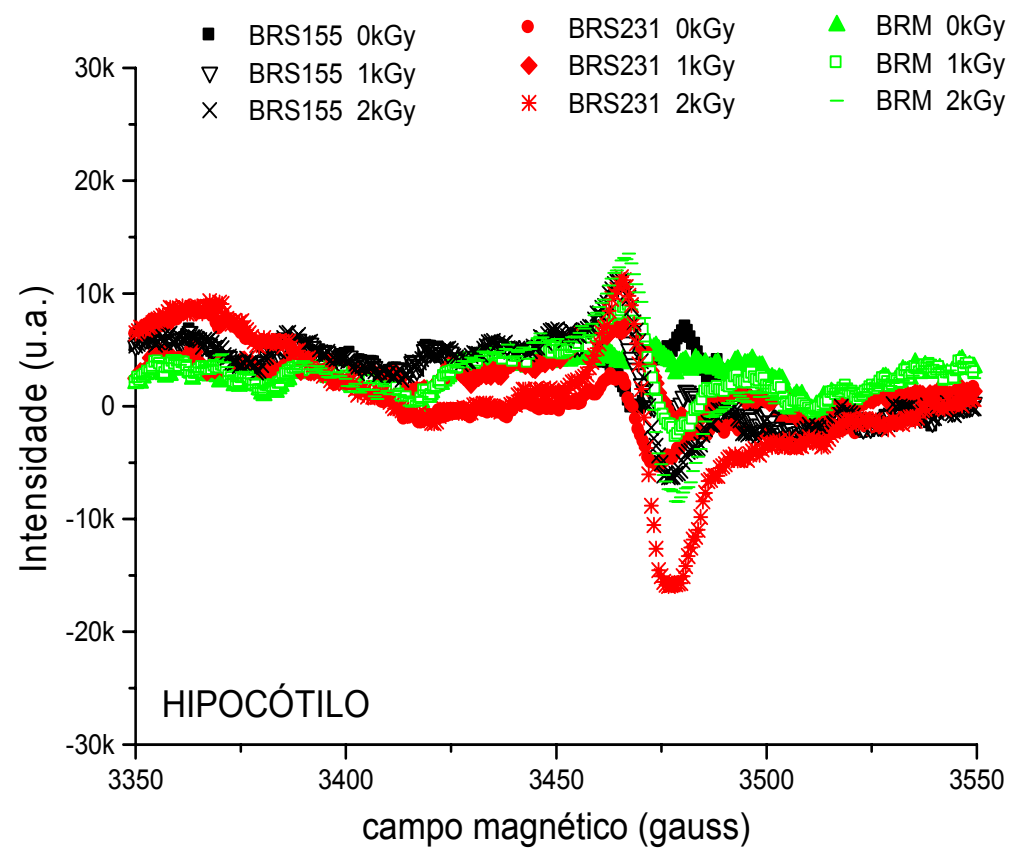

Figura 22. RPE em hipocótilo de três cultivares: não irradiado e irradiado com doses de 1 e 2 kGy. 
Os resultados da ressonância com as partes do grão mostram que tanto o hilo quanto a casca, apesar de não representarem nem $10 \%$ do grão, são fundamentais no sinal central de RPE das cultivares. Praticamente não se observa o pico central nas medidas com o cotilédone. Nos resultados com o hipocótilo, o sinal A está presente com baixa intensidade, porém bastante distorcido.

O sexteto está presente, sobretudo nos cotilédones, que representam boa parte do grão. No hipocótilo e na casca, sua participação é pequena; no hilo, o sinal é desprezível. Estes sinais menores talvez sejam fruto de contaminação, pois uma separação manual das partes será sempre parcial. Desta forma, na hipótese de se utilizar a RPE para dosimetria, o hilo seria a parte mais efetiva. O hipocótilo, sabidamente rico em isoflavonas, só apresentou parte do sinal das cultivares

Um segundo conjunto de cultivares (grãos) da safra 2004/2005 foram irradiados com doses de 0, 1, 5 e $10 \mathrm{kGy}$. Em seguida os pacotes foram enviados para análise no laboratório da Embrapa. Os resultados estão nos gráficos das FIG. 23 a 24. Os resultados representam a média de duas repetições e foram expressos em mg por 100 gramas de amostra. 
IV. 6. Efeito da radiação no conteúdo de isoflavonas

As determinações de isoflavonas foram realizadas pela EMBRAPA (comunicação pessoal do Dr. J. Marcos Mandarino - apêndice III) utilizando extração com etanol após eliminação de gorduras com n-hexano e determinação por cromatografia líquida de alta performance, com erro $\leq 5 \%$. De uma maneira geral a radiação não alterou as quantidades totais de isoflavonas (FIG. 23): apenas numa cultivar, BRS231, houve notório aumento.

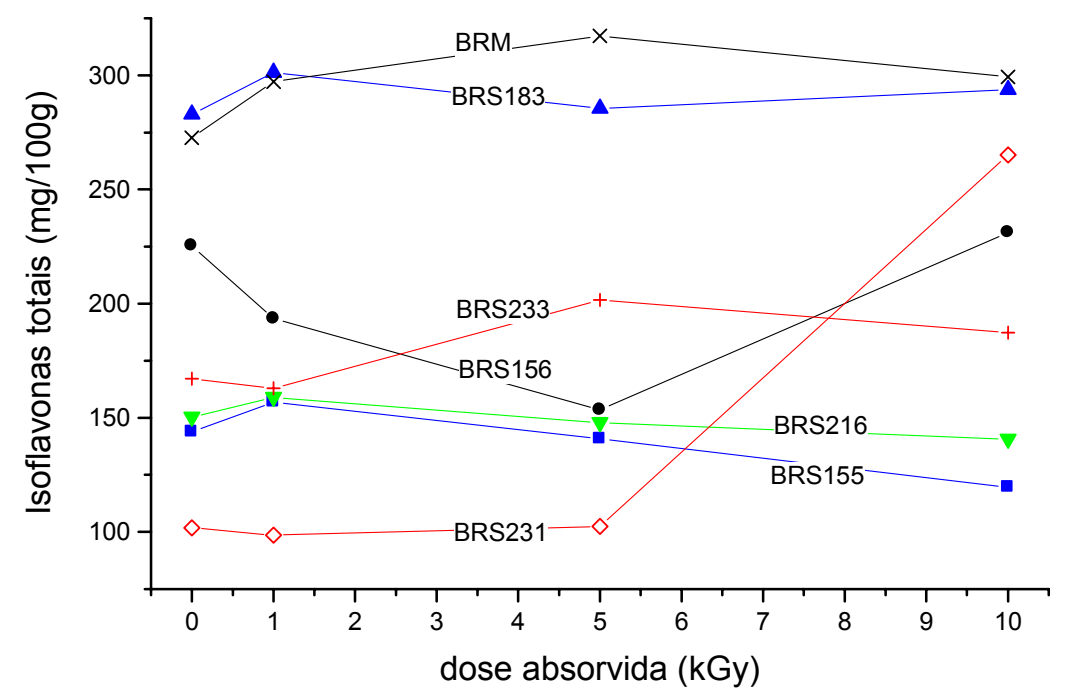

Figura 23. Teor total de isoflavonas em cultivares de soja, safra $2004 / 2005$. As medidas foram feitas para amostras não irradiadas e irradiadas com doses de 0, 1,5 e $10 \mathrm{kGy}$.

Moussaid et al (2000) descreveram que a irradiação com dose de 1 ou 2kGy estimulou a síntese de flavonas na pele de laranjas. Variyar et al. (2004), estudando o comportamento dos compostos fenólicos frente à radiação gama, verificaram que doses entre 0,5 e 5,0 kGy promoveram diminuição dos glicosídeos conjugados e aumento das agliconas nos grãos de soja. 
Da FIG. 24 até a FIG. 32, são apresentadas as variações nas 8 diversas isoflavonas, não irradiadas e irradiadas com doses de até 10kGy.

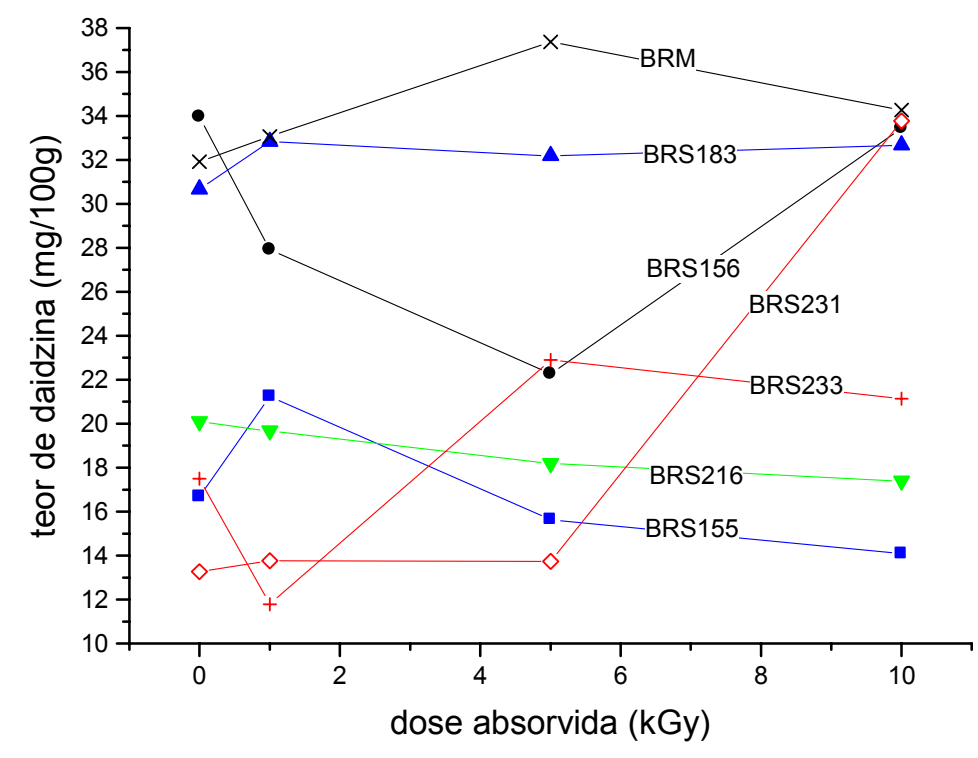

Figura 24. Teores de isoflavonas do tipo daidzina em cultivares de soja, safra 2004/2005 em função da dose de radiação.

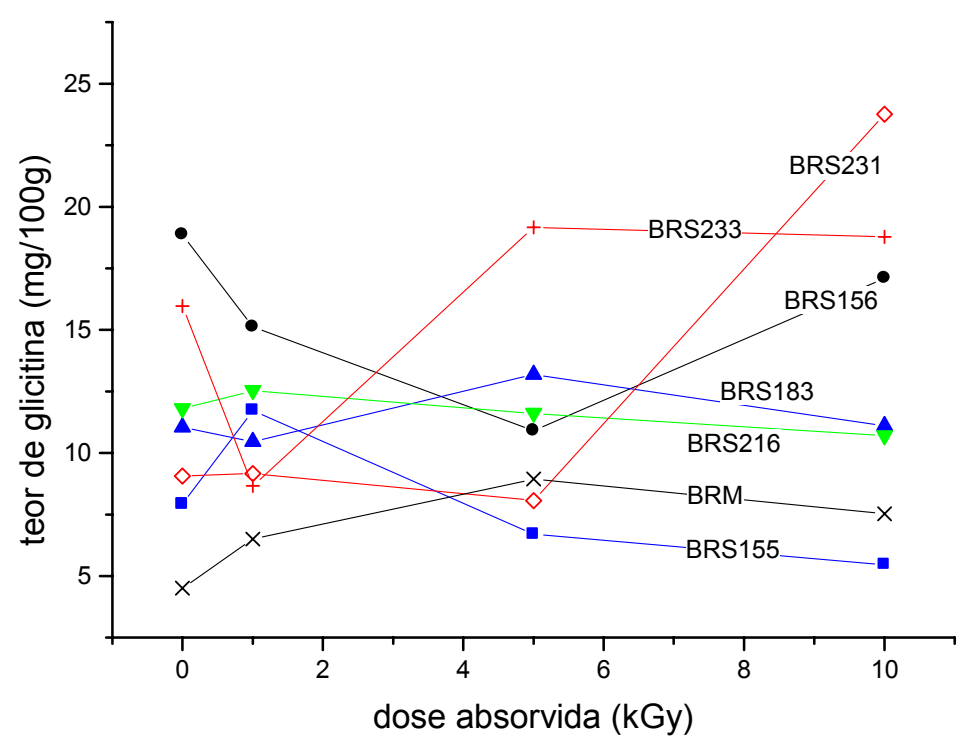

Figura 25. Teores de isoflavonas do tipo glicitina em cultivares de soja, safra 2004/2005 em função da dose de radiação. 


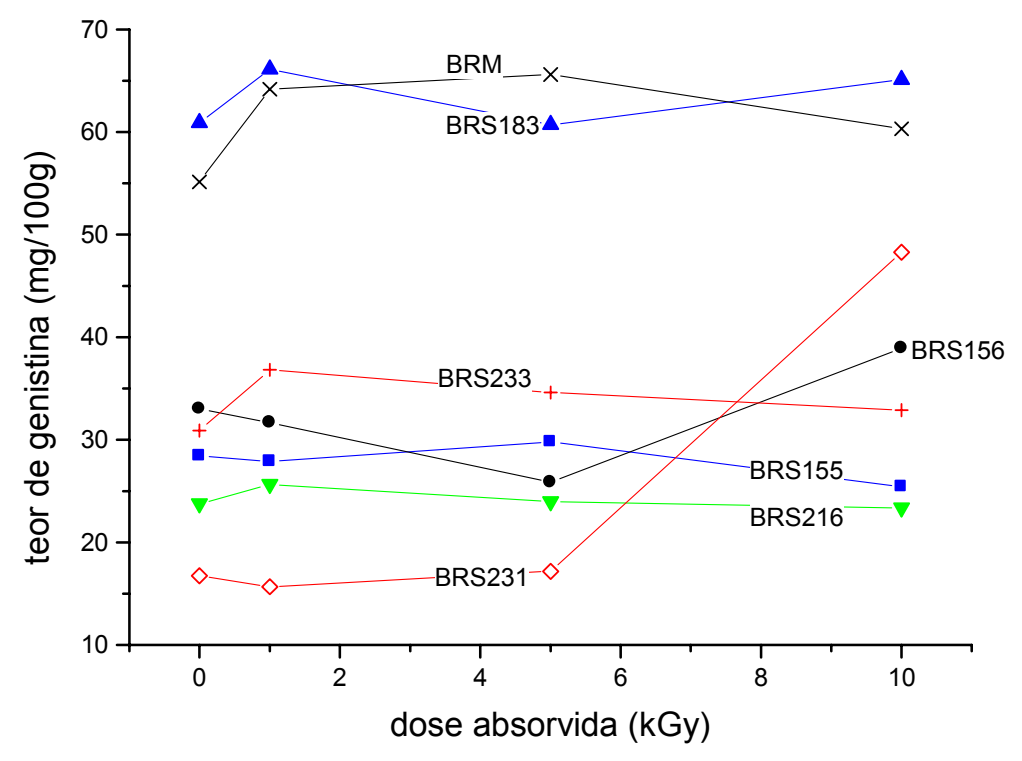

Figura 26. Teores de isoflavonas do tipo genistina em cultivares de soja, safra 2004/2005 em função da dose de radiação.

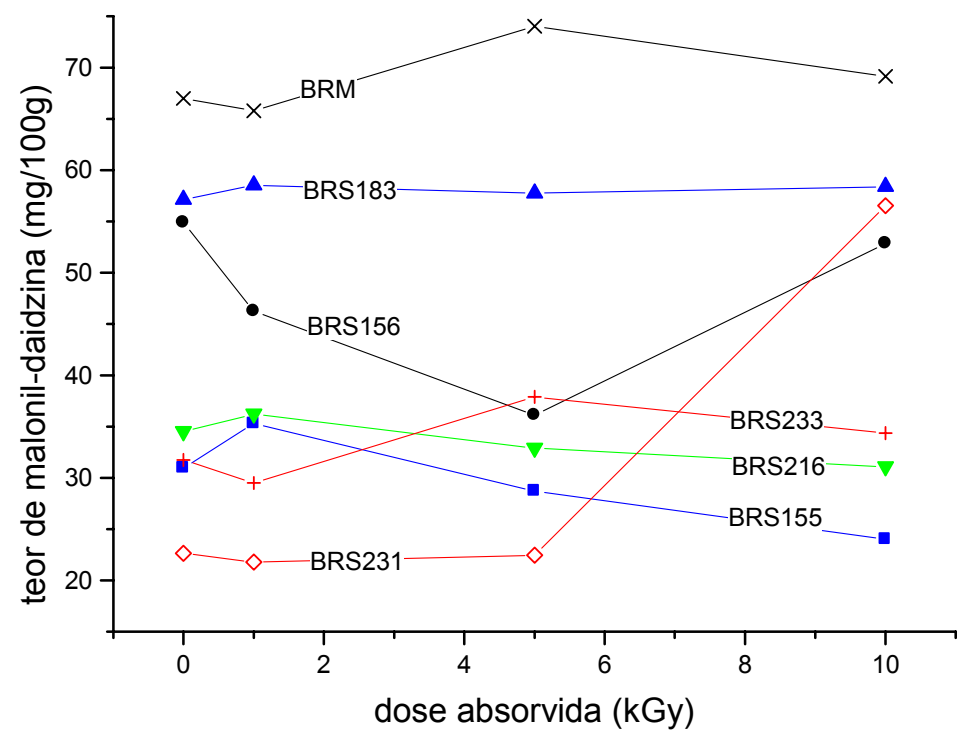

Figura 27. Teores de isoflavonas do tipo malonil-daidzina em cultivares de soja, safra 2004/2005 em função da dose de radiação. 


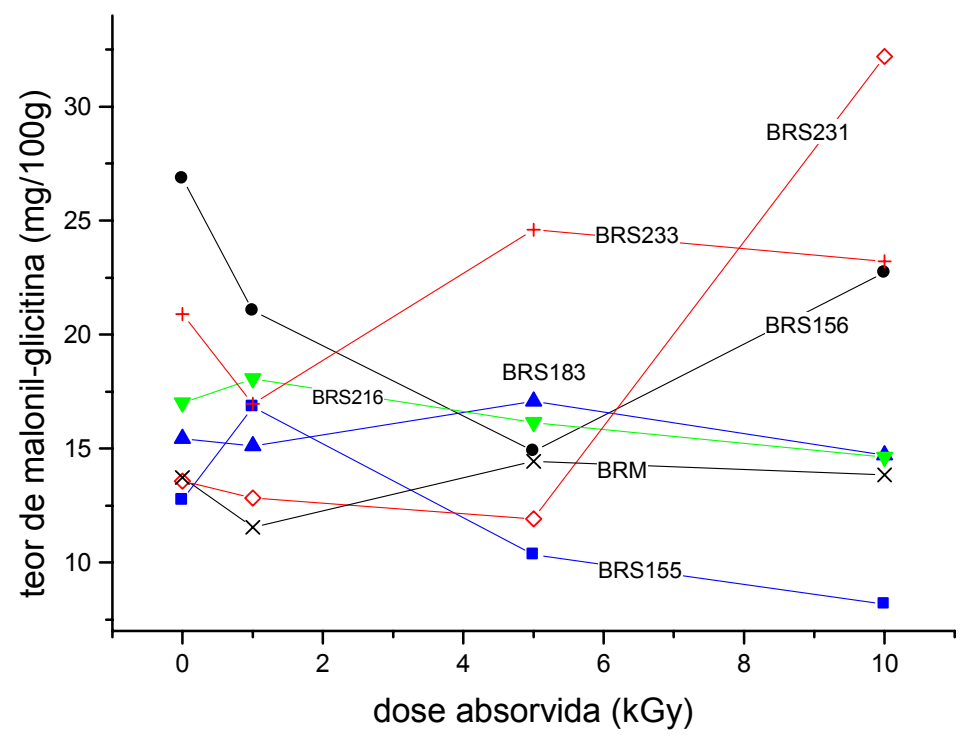

Figura 28. Teores de isoflavonas do tipo malonil-glicitina em cultivares de soja, safra 2004/2005 em função da dose de radiação.

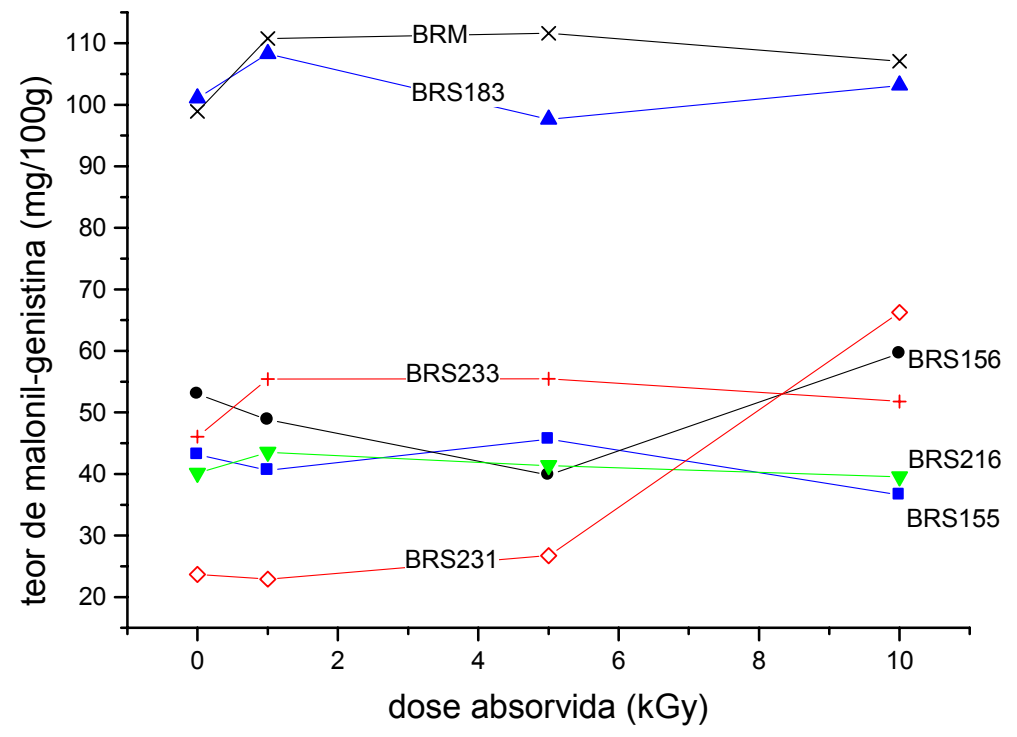

Figura 29. Teores de isoflavonas do tipo malonil-genistina em cultivares de soja, safra 2004/2005 em função da dose de radiação. 


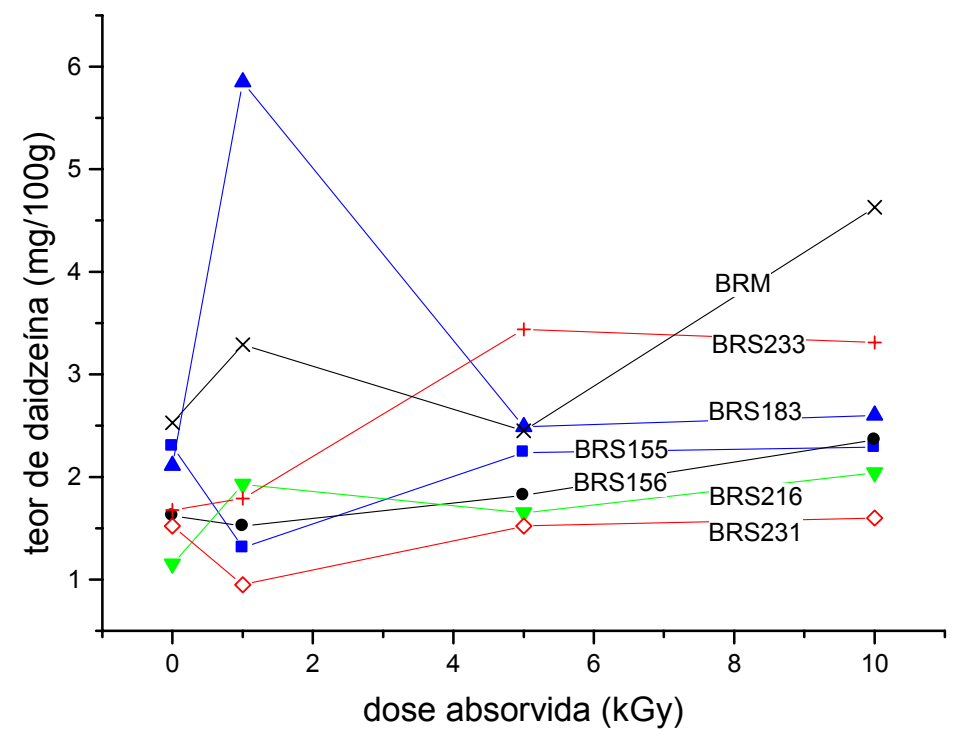

Figura 30. Teores de isoflavonas do tipo daidzeína em cultivares de soja, safra 2004/2005 em função da dose de radiação.

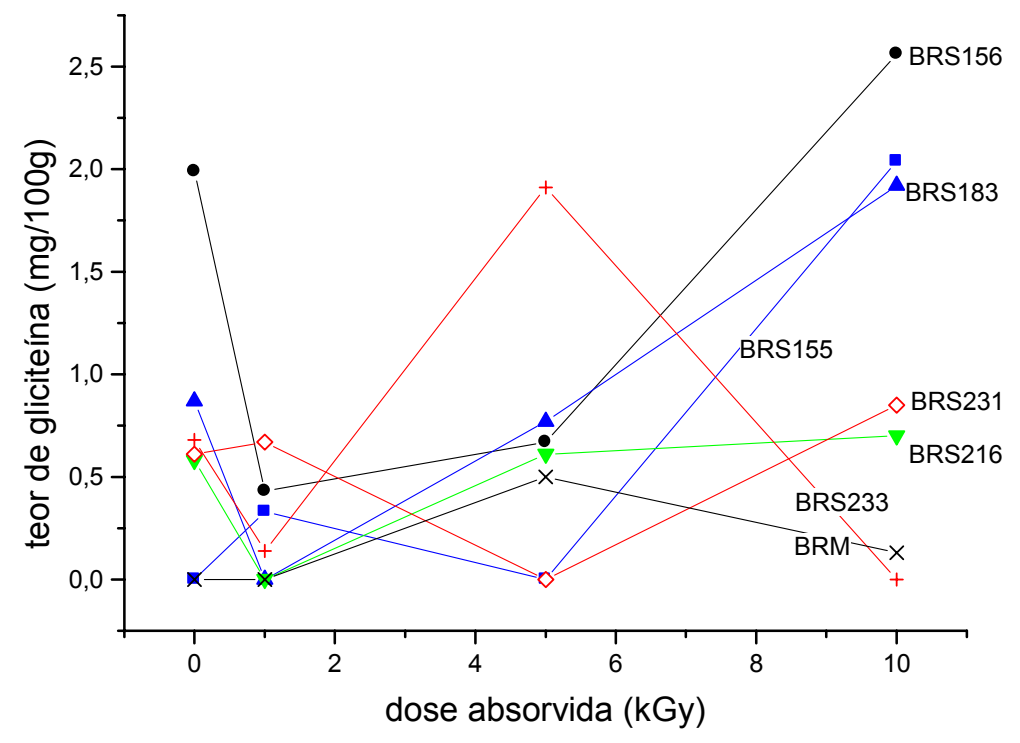

Figura 31. Teores de isoflavonas do tipo gliciteína em cultivares de soja, safra 2004/2005 em função da dose de radiação. 


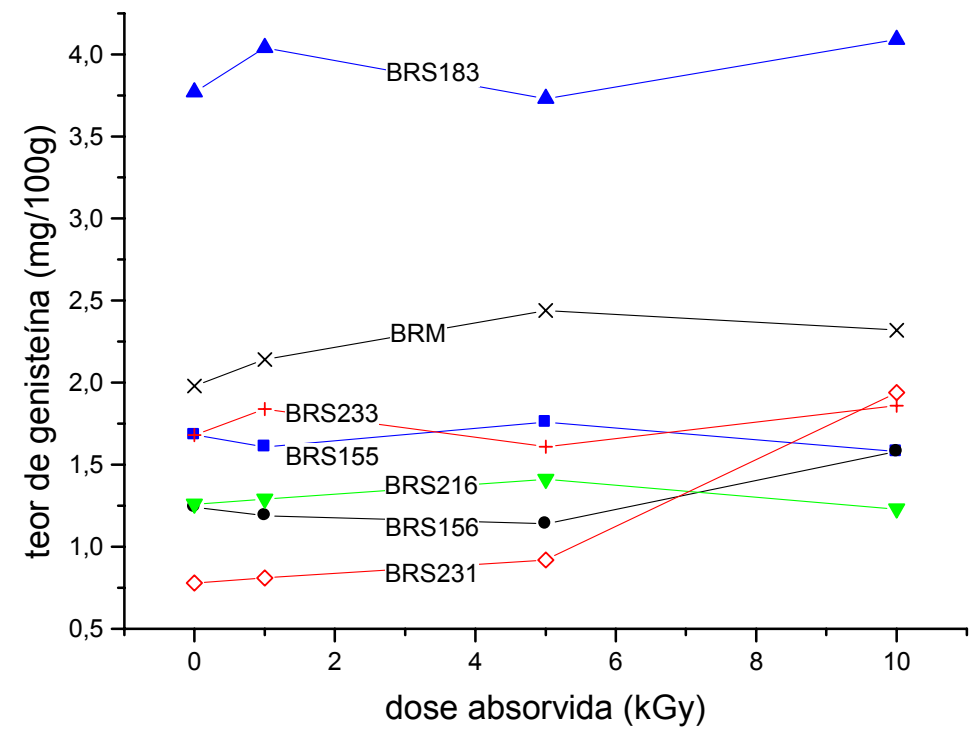

Figura 32. Teores de isoflavonas do tipo genisteína em cultivares de soja, safra 2004/2005 em função da dose de radiação.

Para a maior parte dos tipos de isoflavonas, não há uma tendência clara de aumento ou diminuição de seus teores médios ( 7 cultivares) com o aumento da dose. De fato, se forem comparados os teores médios de isoflavonas totais e parciais, em amostras irradiadas e não irradiadas, dentro de um nível de significância de $5 \%$, só há variação para a daidzeína, irradiada com dose de 10kGy (apêndice II).

No entanto, se forem consideradas algumas cultivares apenas, e não os valores médios, percebe-se comportamentos reiterados. Nas cultivares BRS155 e BRS216, nota-se uma diminuição nas quantidades de isoflavonas glicosadas (FIG. 24 a 29), ao passo que nos gráficos das isoflavonas livres (agliconas) a tendência se inverte, isto é, os teores aumentam com a dose de uma maneira geral (FIG. 30 a 32). Cabe ressaltar também que a cultivar BRS231, irradiada com 10kGy, apresentou sistematicamente os maiores teores de isoflavonas, sobretudo na forma glicosada. 
Ao menos para a dose mais elevada, percebe-se claramente um aumento nos teores de agliconas para todas as cultivares testadas. Há portanto indícios de que a radiação possa estar convertendo os tipos glicosados em agliconas, estas de maior biodisponibilidade, e portanto mais interessantes ao consumo humano. Segundo Park et al. (2001), flavonóides agliconas apresentam atividades antioxidantes maiores do que suas formas conjugadas correspondentes.

Variyar et al. (2004) estudando o comportamento dos compostos fenólicos frente à irradiação gama, verificaram que doses entre 0,5 e 5,0 kGy promoveram diminuição dos glicosídeos conjugados e aumento das agliconas nos grãos de soja.

Toledo (2006), estudando alterações promovidas por doses de irradiação de 2,4 e 8,0 kGy em grãos de soja crus e cozidos, encontrou redução no teor de compostos fenólicos totais até a dose de $4 \mathrm{kGy}$ e um aumento com a dose de $8 \mathrm{kGy}$. Nessas doses também foram reduzidos os teores de tripsina e taninos. 
IV.7. Pasta de Isoflavona

A Isoflavine apresentou o mesmo pico A das cultivares de soja. Na FIG. 33 está o resultado das leituras por RPE do complexo de isoflavonas irradiado com 2,5; 5,0 e 10,0 kGy e não irradiado.

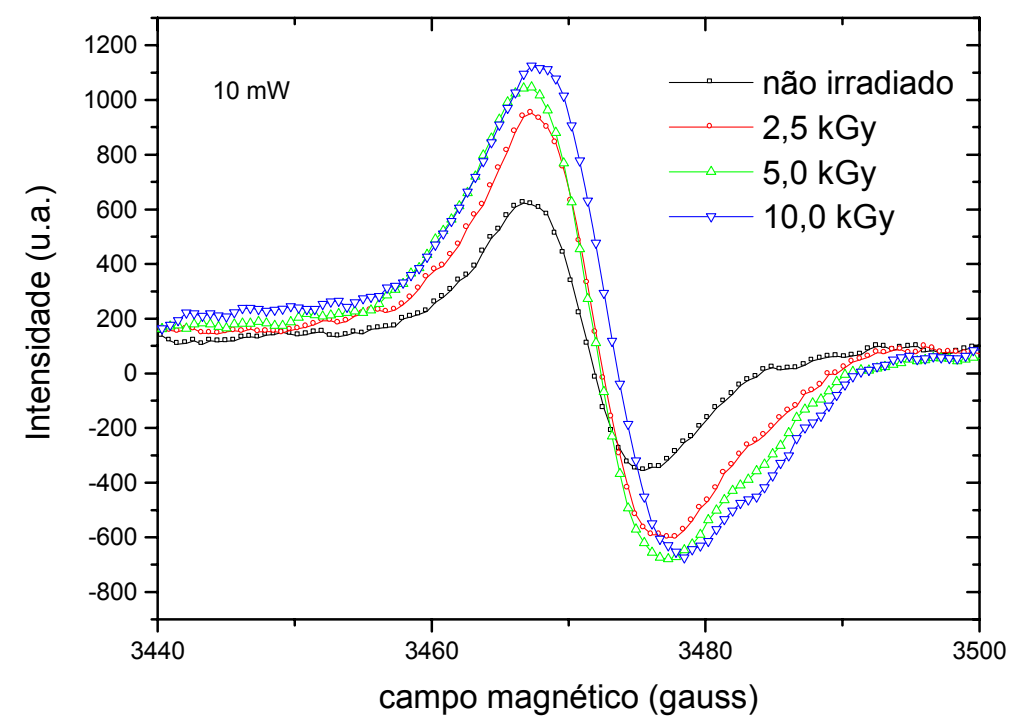

Figura 33. RPE de amostras de Isoflavine não-irradiadas e irradiadas com doses de 2,5, 5,0 e 10,0 kGy.O intervalo ressalta apenas o que parece ser o sinal $A$, visto nas cultivares de soja.

Fica evidente que neste produto preparado a partir de soja, o sinal é proveniente do mesmo grupo detectado anteriormente no próprio grão de soja.

Há um acréscimo na intensidade como consequência da irradiação, do que presumivelmente é o pico A, observado nas cultivares de soja. Para evidenciar essa semelhança, na FIG. 34, é apresentada uma sobreposição feita dos picos de uma das cultivares, BRS 155 e aquele observado na Isoflavine, ambos irradiados com $10 k G y$. 


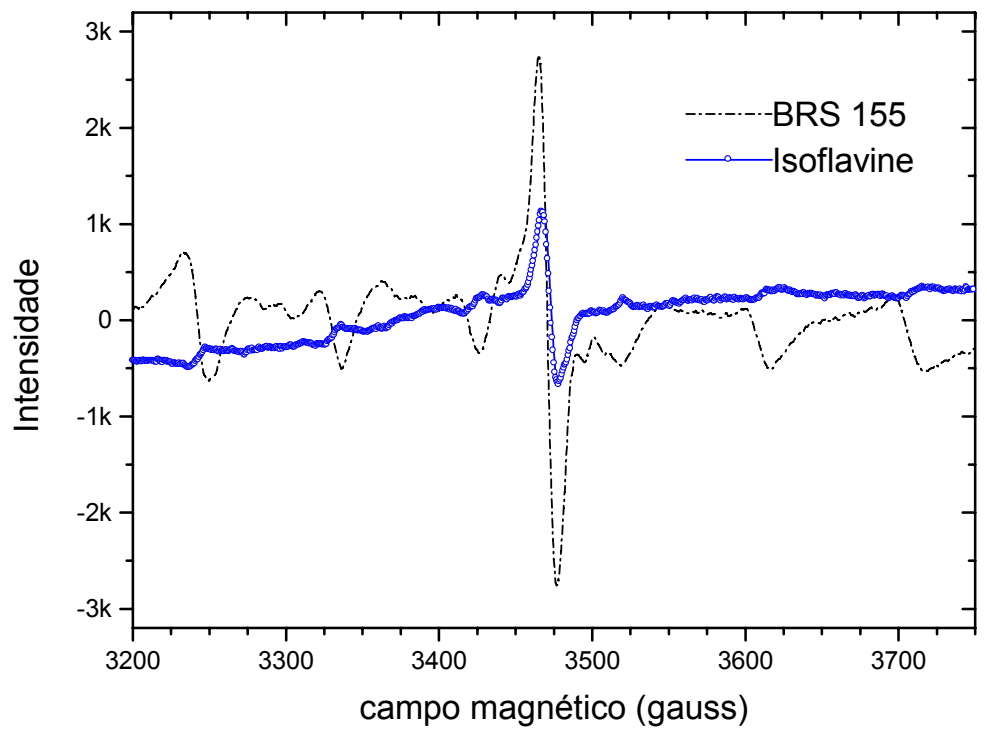

Figura 34. RPE de Isoflavine e da cultivar BRS 155, ambas irradiadas com 10,0 kGy.

Trata-se provavelmente do mesmo tipo de radical. Nota-se, com intensidade bastante reduzida, até mesmo o sexteto devido ao $\mathrm{Mn}^{2+}$. 


\section{CONSIDERAÇÕES FINAIS}

Os organismos que vivem em ambiente aeróbico foram forçados a desenvolver estratégias celulares efetivas para detoxificar espécies reativas de oxigênio (Miura, 2004). As respostas adaptativas, especialmente contra efeitos da radiação, são mecanismos defensivos de regulação pelos quais o estresse oxidativo induz uma resposta contra o dano.

Diversos autores (Wang e Murphy, 1994; Carrão-Panizzi et al., 1998; Genovese et al., 2005) constataram a grande disparidade no conteúdo de isoflavonas, importantes antioxidantes contidos na soja, atribuídas fundamentalmente a diferenças de temperatura, composição do solo e disponibilidade hídrica. Neste sentido, Ávila et al. (2007) verificaram variações significativas principalmente para as formas malonil. Tem sido sugerido que esses compostos estariam envolvidos na proteção contra a radiação UV de componentes celulares vitais das plantas (Smith e Markham, 1996).

No presente trabalho não foi encontrada uma correlação entre a geração de radicais livres induzida pela radiação e o conteúdo de antioxidantes do tipo das isoflavonas. Também não se percebe uma ação direta da radiação capaz de modificar sistematicamente e significativamente o conteúdo desses antioxidantes celulares. Dados obtidos no presente estudo, no entanto, sugerem que algumas isoflavonas (glicitina) contidas na soja modificam os efeitos da radiação ionizante. Nesse caso, os antioxidantes estariam reduzindo o nível de radicais livres produzidos pela radiação, tal como é observado em testes in vivo (Day et al., 2008).

Os resultados das medidas por RPE de Isoflavine permitiram apenas uma associação do sinal com aquele obtido em amostras de soja. Talvez pudesse ser obtida mais informação se as medidas fossem feitas com as isoflavonas isoladas, e não em um composto apenas rico em isoflavonas. 
A espectroscopia por RPE se mostrou um método físico adequado para o estudo da geração de radicais livres em produtos com baixo conteúdo de umidade como é o caso de grãos de soja. 


\section{CONCLUSÕES}

1. Foi observada uma relação entre a dose de radiação gama absorvida pela amostra e a altura do sinal de RPE (pico A). O sinal se mostrou bastante estável, persistindo mesmo após decorridos 7 meses da irradiação. Desta forma, pode-se utilizar a técnica para identificação de soja irradiada dentro daquele intervalo de tempo.

2. Não ficou estabelecida uma correlação entre o conteúdo total de isoflavonas e o sinal de RPE proveniente de radicais livres gerados pela radiação.

3. No entanto, há indícios de que os conteúdos de alguns tipos de isoflavonas e o sinal proveniente de radicais livres gerados pela radiação estejam correlacionados. Os teores de $\beta$-glicitina e acetil-daizina mantiveram uma correlação negativa com a altura do sinal de RPE estudado, a depender da safra investigada. Variações significativas nos teores desses antioxidantes quando comparadas as duas safras, não levam a uma convergência dos resultados.

4. Os resultados com as partes do grão de soja se mostraram extremamente úteis, uma vez que ficou evidente que o hilo e a casca, apesar de não representarem nem $10 \%$ do grão, são fundamentais no sinal de RPE das cultivares. Assim, na hipótese de se utilizar a RPE para dosimetria, o hilo seria a parte mais efetiva. $O$ hipocótilo, sabidamente rico em isoflavonas, só apresentou parte do sinal das cultivares. 


\section{APÊNDICE I}

\section{Correlação Linear}

Sejam $\left(x_{1}, x_{2}, \ldots, x_{n}\right)$ e $\left(y_{1}, y_{2}, \ldots, y_{n}\right)$ dois conjuntos de dados para as variáveis $\mathrm{x}$ e y, então o coeficiente $r$ de correlação linear (Pearson) é definido pela expressão:

$$
\begin{aligned}
& r=\frac{S x y}{S x S y}, \text { onde } \\
& S x y=\frac{\sum_{i=1}^{n}\left(x_{i}-\bar{x}\right)\left(y_{i}-\bar{y}\right)}{n-1} \text { é a covariância entre as variáveis, e } \\
& S x=\sum_{i=1}^{n} \sqrt{\frac{\left(x_{i}-\bar{x}\right)^{2}}{n-1}} \text { e } S y=\sum_{i=1}^{n} \sqrt{\frac{\left(y_{i}-\bar{y}\right)^{2}}{n-1}} \text { são os desvios-padrão das variáveis. }
\end{aligned}
$$

Para que se possa comparar o valor medido de $r$ com o respectivo valor verdadeiro $\rho$, e portanto decidir acerca da plausibilidade de haver ou não correlação, pode-se lançar mão de um teste de hipótese. Dentro de um nível de significância $\alpha$, as seguintes hipóteses são testadas:

Ho: $\rho=0$ (não há correlação)

$H 1: \rho \neq 0$

O teste é feito através de uma estatística com o parâmetro t-Student (Costa Neto, 2002). Para o valor medido de $r$, calcula-se o respectivo valor de $t$, através da expressão

$$
t_{n-2}=r \sqrt{\frac{n-2}{1-r^{2}}} \text {, onde n-2 é o número de graus de liberdade do cálculo. }
$$


$\mathrm{Na}$ tabela abaixo, há alguns valores críticos para a variável t. Se o valor $t_{n-2}$ calculado for maior que o valor crítico, então rejeita-se a hipótese Ho dentro do nível de significância pré-determinado.

Tabela I.a Distribuição t-Student (unicaudal). Ps é a probabilidade de que $t_{n-2} \geq t_{\text {crítico, }}$, g. I. = n-2 é o número de graus de liberdade (adaptado de Spiegel (1993)).

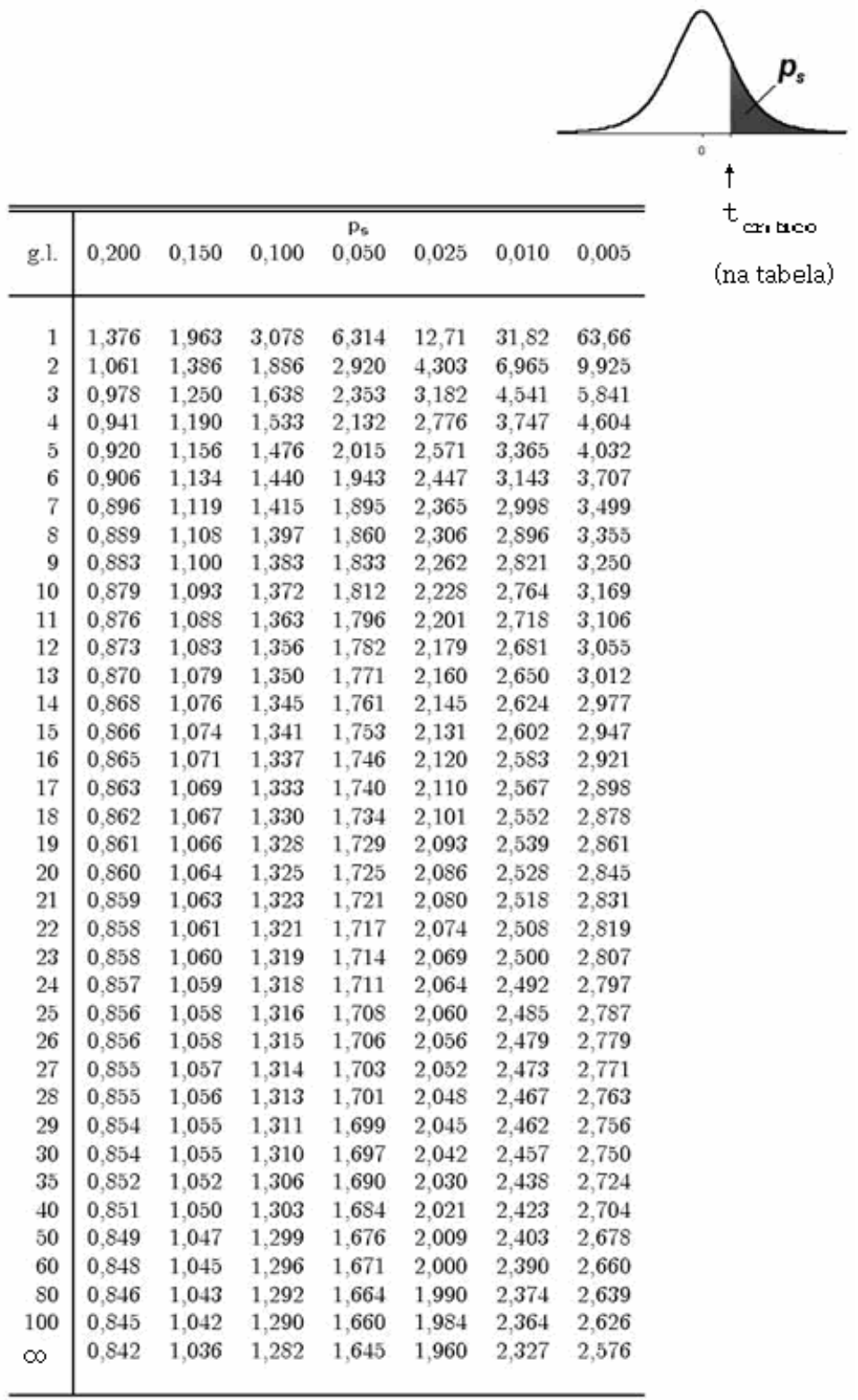


Nas tabelas I.b e I.c foram calculados os valores do parâmetro t-Student, para as correlações da Seção IV.3 (pág. 35), entre os sinais de RPE e os teores das amostras. Considerou-se um nível de significância de $5 \%$, ou seja, tc $=2,015$, para safra 2004/05 e tc=1,782, para a safra 2002/03 (conforme tabela I.a).

Tabela Ib. Correlação linear entre a composição de isoflavonas (total e parcial) das 07 cultivares da safra 2004/05 e a intensidade do sinal A (pico a pico). Com 5 graus de liberdade tc $=2,015$, para $\alpha=5 \%$.

\begin{tabular}{|c|c|c|c|c|c|c|c|c|c|}
\hline \multirow{2}{*}{$\begin{array}{l}\text { dose } \\
\text { (kGy) }\end{array}$} & \multicolumn{3}{|c|}{ beta } & \multicolumn{3}{|c|}{ malonil } & \multicolumn{2}{|c|}{ agliconas } & \multirow{2}{*}{ total } \\
\hline & dai & gli & gen & dai & $\begin{array}{c}\text { gli } \\
\text { índice }\end{array}$ & $\mathbf{r}^{\text {gen }}$ & dai & gen & \\
\hline 2,5 & $-0,38$ & $-0,76$ & 0,49 & 0,41 & 0,51 & $-0,16$ & $-0,22$ & $-0,32$ & $-0,34$ \\
\hline 5,0 & $-0,46$ & $-0,84$ & 0,37 & 0,48 & 0,51 & $-0,26$ & $-0,35$ & $-0,44$ & $-0,48$ \\
\hline 10,0 & $-0,48$ & $-0,71$ & 0,47 & 0,40 & 0,65 & 0,04 & $-0,34$ & $-0,44$ & $-0,27$ \\
\hline \multirow[t]{2}{*}{15,0} & $-0,43$ & $-0,78$ & 0,48 & 0,49 & 0,57 & $-0,05$ & $-0,33$ & $-0,43$ & $-0,32$ \\
\hline & \multicolumn{9}{|c|}{$t_{n-2}$} \\
\hline 2,5 & $-0,93$ & $-2,61$ & 1,27 & 1,00 & 1,32 & $-0,36$ & $-0,51$ & $-0,75$ & $-0,73$ \\
\hline 5,0 & $-1,14$ & $-3,43$ & 0,89 & 1,21 & 1,33 & $-0,60$ & $-0,85$ & $-1,10$ & $-1,12$ \\
\hline 10,0 & $-1,24$ & $-2,23$ & 1,19 & 0,98 & 1,90 & 0,08 & $-0,81$ & $-1,09$ & $-0,50$ \\
\hline 15,0 & $-1,08$ & $-2,83$ & 1,23 & 1,27 & 1,55 & $-0,11$ & $-0,79$ & $-1,07$ & $-0,63$ \\
\hline
\end{tabular}

Tabela I.c. Correlação linear entre a composição de isoflavonas (total e parcial) das 14 cultivares da safra 2002/03 e a intensidade do sinal A (pico a pico). Com 12 graus de liberdade, $t_{c}=1,782$, para $\alpha=5 \%$.

\begin{tabular}{|c|c|c|c|c|c|c|c|c|c|c|c|c|}
\hline \multirow{3}{*}{$\begin{array}{l}\text { dose } \\
\text { (kGy) }\end{array}$} & \multicolumn{3}{|c|}{ beta } & \multicolumn{3}{|c|}{ malonil } & \multicolumn{2}{|c|}{ acetil } & \multicolumn{3}{|c|}{ agliconas } & total \\
\hline & \multicolumn{12}{|c|}{ índice $r$} \\
\hline & dai & gli & gen & dai & gli & gen & dai & gen & dai & gli & gen & total \\
\hline 1,0 & $-0,57$ & $-0,13$ & $-0,46$ & $-0,36$ & $-0,35$ & $-0,34$ & $-0,57$ & $-0,67$ & $-0,57$ & $-0,74$ & $-0,76$ & $-0,53$ \\
\hline 4,0 & $-0,27$ & 0,11 & $-0,40$ & $-0,12$ & $-0,29$ & $-0,40$ & $-0,53$ & $-0,44$ & $-0,27$ & $-0,37$ & $-0,40$ & $-0,34$ \\
\hline 8,0 & $-0,32$ & 0,05 & $-0,42$ & $-0,38$ & $-0,50$ & $-0,55$ & $-0,59$ & $-0,59$ & $-0,32$ & $-0,38$ & $-0,38$ & $-0,45$ \\
\hline \multirow[t]{2}{*}{13,0} & 0,08 & 0,53 & $-0,07$ & 0,13 & 0,14 & $-0,20$ & $-0,16$ & $-0,39$ & 0,08 & $-0,16$ & $-0,23$ & 0,00 \\
\hline & \multicolumn{12}{|c|}{$t_{n-2}$} \\
\hline 1,0 & 0,28 & $-0,46$ & $-1,80$ & $-1,32$ & $-1,31$ & $-1,26$ & $-2,37$ & $-3,12$ & $-2,38$ & $-3,83$ & $-4,09$ & $-2,18$ \\
\hline 4,0 & $-0,97$ & 0,38 & $-1,52$ & $-0,44$ & $-1,05$ & $-1,53$ & $-2,18$ & $-1,69$ & $-0,97$ & $-1,36$ & $-1,51$ & $-1,27$ \\
\hline 8,0 & $-1,18$ & 0,18 & $-1,61$ & $-1,43$ & $-1,98$ & $-2,29$ & $-2,53$ & $-2,53$ & $-1,18$ & $-1,42$ & $-1,43$ & $-1,75$ \\
\hline 13,0 & 0,28 & 2,17 & $-0,24$ & 0,44 & 0,48 & $-0,70$ & $-0,58$ & $-1,48$ & 0,28 & $-0,55$ & $-0,83$ & 0,00 \\
\hline
\end{tabular}


Safra 2004/05

Os valores críticos só foram superados para os teores de $\beta$-gliciteína (compararação feita com os módulos de $t_{n-2}$ e $t_{c}$ ), qualquer que fosse a dose. Desta forma, só para aquela isoflavona é que se pode afirmar que a correlação não é nula. De fato, há uma forte correlação negativa, indicando que quanto maior a quantidade de $\beta$-gliciteína presente na cultivar, menor o efeito da radiação detectado pela RPE. Se as hipóteses forem consideradas dentro de um nível de significância de $1 \%$ (tc=3,365), então não se pode afirmar que haja qualquer correlação entre as variáveis analisadas.

Safra 2002/03

Dentro de um nível de significância de $5 \%$ (tc=1,782), dentre as 48 correlações estabelecidas, não se pode rejeitar a hipótese de que $\rho=0$ para onze dela. Nessas condições também foi observada uma correlação com o teor total, irradiado com $1 \mathrm{kGy}$. Nessas circunstâncias, chama a atenção em particular, os resultados com o teor de acetil-daidzina, onde uma correlação negativa foi verificada para três das quatro doses empregadas. Vale ressaltar que a forma acetil não havia sido detectada nas análies da safra 2004/05, provavelmente por diferenças na metodologia utilizada. Se levar em conta um nível de significância de 1\%, então só se pode afirmar que haja correlação em 2 das medidas (gliciteína e genisteína, para dose de 1,0 kGy). 


\section{APÊNDICE II}

\section{Metodologia para extração e quantificação de isoflavonas em grãos de soja - Laboratório EMBRAPA-SOJA}

A extração das isoflavonas foi realizada de acordo com a metodologia de Carrão-Panizzi et al., 2002, onde as amostras (sementes) foram trituradas em micro moinho analítico e desengorduradas com n-hexano, em temperatura ambiente, sob agitação constante por 8 horas. $100 \mathrm{mg}$ de cada amostra triturada e desengordurada foram transferidas para tubos de ensaio de $10 \mathrm{~mL}$ com tampa rosqueável. Em seguida foram adicionados $4,0 \mathrm{~mL}$ de solução de etanol $70 \%$, contendo $0,1 \%$ de ácido acético. Os tubos contendo as amostras e a solução extratora foram homogeneizados em agitador de tubos do tipo "Vortex" e submetidos à extração por uma hora em temperatura ambiente. A cada intervalo de 15 minutos os tubos eram agitados com o auxílio do agitador de tubos. $1,5 \mathrm{~mL}$ do extrato foram transferidos para tubos de microcentrífuga do "tipo Ependorff", e centrifugados por 15 minutos a $14.000 \mathrm{rpm}$, numa temperatura de $5^{\circ} \mathrm{C}$. O sobrenadante foi filtrado através de membrana com poros de $0,45 \mu \mathrm{m}$, da marca "Millipore". $20 \mu \mathrm{L}$ do extrato filtrado foram utilizados para injeção no cromatógrafo líquido.

A separação e a quantificação das isoflavonas foi realizada de acordo com a metodologia preconizada por Berhow, 2002, em cromatógrafo líquido da marca Waters, modelo 2690, com injetor automático de amostras. Utilizou-se, para tanto, uma coluna de fase reversa do tipo ODS C18 (YMC Pack ODS-AM Columm) com $250 \mathrm{~mm}$ de comprimento $\times 0,4 \mathrm{~mm}$ de diâmetro interno e partículas de $5 \mu \mathrm{m}$. Para a separação das isoflavonas, adotou-se o sistema de gradiente linear binário, tendo-se como fases móveis: 1) metanol contendo $0,025 \%$ ácido trifluoroacético (TFA) (solvente A) e 2) água destilada deionizada ultrapura contendo $0,025 \%$ de TFA (solvente B). A condição inicial do gradiente foi de $20 \%$ para o solvente $A$, que aos 40 minutos atingiu a concentração de $100 \%$ para, em seguida, retornar à $20 \%$ aos 41 minutos e permanecer nestas condições até os 60 minutos. Portanto, o tempo total 
de corrida para cada amostra foi de 60 minutos. A vazão da fase móvel foi de 1 $\mathrm{mL} / \mathrm{min}$ e a temperatura durante a corrida, $25^{\circ} \mathrm{C}$. Para a detecção das isoflavonas, foi utilizado o detector de arranjo de foto diodo da marca Waters, modelo 996, ajustado para o comprimento de onda igual à $260 \mathrm{~nm}$. Para a identificação dos picos correspondentes à cada uma das isoflavonas foram utilizados padrões de daidzina, daidzeína, genistina e genisteína, da marca Sigma, solubilizados em metanol (grau HPLC), nas seguintes concentrações: $0,00625 \mathrm{mg} / \mathrm{mL} ; 0,0125 \mathrm{mg} / \mathrm{mL} ; 0,0250$ $\mathrm{mg} / \mathrm{mL} ; 0,0500 \mathrm{mg} / \mathrm{mL}$ e $0,1000 \mathrm{mg} / \mathrm{mL}$. Para a quantificação das 12 formas de isoflavonas, por padronização externa (área dos picos), foram utilizados os padrões como referência, bem como o coeficiente de extinção molar de cada uma delas para o cálculo das outras formas (malonil e acetil).

BERHOW, M. A. Modern analytical techniques for flavonoid determination. In: BUSLIG, B. S.; MANTHEY, J. A. (ed.). Flavonoids in the living cell. New York: Klusher Academic, 2002. p.61-76. (Adv. Exp. Méd. Biol. v. 505).

CARRÃO-PANIZZI, M.C.; FAVONI, S.P.G.; KIKUCHI, A. Extraction time for isoflavone determination. Brazilian Archives of Biology and Technology, Curitiba, v.45, n.4, p.515-518, Dec. 2002.

COMUNICAÇÃO RECEBIDA DE:

José Marcos Gontijo Mandarino

Pesquisador da Embrapa Soja

Área Técnica: Genética e Melhoramento

Núcleo Temático: Utilização e Segurança Alimentar 


\section{APÊNDICE III}

\section{Teores de Isoflavonas em amostras irradiadas ou não}

Os teores totais e parciais de isoflavonas fornecidos pela EMBRAPA (colunas 2, 3, 4 e 5 da tabela III.a) foram tratados neste traballho utilizando-se um teste de hipótese levando-se em conta as médias nas diferenças entre os valores não irradiados e irradiados com três doses.

Convencionou-se chamar de $\mathrm{d}_{1}$ a diferença entre o teor de isoflavona de uma amostra irradiada com a primeira dose ( $1 \mathrm{kGy})$ e o respectivo teor para a cultivar não irradiada, e assim por diante para as outras duas doses (dose 2: 5kGy e dose 3: 10 kGy).

Foram calculados os valores médios da tripla $\left(\mathrm{d}_{1}, \mathrm{~d}_{2}, \mathrm{~d}_{3}\right)$ para todos os tipos detectados de isoflavonas, e respectivos desvios-padrão. As médias foram comparadas, dentro de um nível de significância de $5 \%$, com o que se esperaria caso não houvesse variação alguma em função da radiação, isto é, $d=0$ (hipótese Ho). $O$ valor crítico $t_{(6 ; 2,5 \%)}=2,447$ (Tabela I.a) só foi superado para o teor de daidzeína na comparação entre a útlima dose e a amostra não irradiada, isto é, para $d_{3}$. Desta forma, só se pode afirmar que houve variação entre os teores das cultivares irradiadas e não irradiadas para aquela situação.

Nas estatística do tipo t-Student utilizou-se a fórmula $t_{n-1}=\frac{\bar{d}-\Delta}{s_{d} / \sqrt{n}}$, onde d é a diferença entre duas variáveis, $\Delta \circ$ valor testado para d (neste caso, $\Delta=0), \mathrm{n}$ o número da amostra das $\mathrm{e} \mathrm{s}_{\mathrm{d}} \mathrm{O}$ desvio padrão em $\mathrm{d}$. 
Tabela III.a. Isoflavonas em mg/100g para cultivares de soja não irradiadas e irradiadas com doses de 1, 5 e $10 \mathrm{kGy}$. Os valores expressam médias de duas medidas, descartadas variações acima de $5 \%$. As colunas d1, d2 e d3, trazem as diferenças entre os teores irradiados e não irradiados (doses de 1, 5 e $10 \mathrm{kGy}$ respectivamente.

\begin{tabular}{|c|c|c|c|c|c|c|c|}
\hline $\begin{array}{c}\text { isoflavonas } \\
\text { totais }\end{array}$ & $0 \mathrm{kGy}$ & $1 \mathrm{kGy}$ & $5 \mathrm{kGy}$ & $10 \mathrm{kGy}$ & d1 & d2 & d3 \\
\hline BRS155 & 143,88 & 156,83 & 140,81 & 119,61 & 12,95 & $-3,07$ & $-24,27$ \\
\hline BRS156 & 225,42 & 193,44 & 153,49 & 231,15 & $-31,98$ & $-71,93$ & 5,73 \\
\hline BRS183 & 283 & 301,23 & 285,48 & 293,78 & 18,23 & 2,48 & 10,78 \\
\hline BRS216 & 150,26 & 158,87 & 147,84 & 140,63 & 8,61 & $-2,42$ & $-9,63$ \\
\hline BRS231 & 101,87 & 98,55 & 102,5 & 265,19 & $-3,32$ & 0,63 & 163,32 \\
\hline BRS233 & 167,12 & 162,88 & 201,56 & 187,33 & $-4,24$ & 34,44 & 20,21 \\
\hline BRM & 272,76 & 297,28 & 317,33 & 299,32 & 24,52 & 44,57 & 26,56 \\
\hline média & 192,04 & 195,58 & 192,72 & 219,57 & 3,54 & 0,67 & 27,53 \\
\hline \multirow[t]{2}{*}{ desvio padrão } & 69,19 & 76,20 & 80,21 & 72,28 & 18,88 & 37,34 & 62,33 \\
\hline & & & & t6 & 0,46 & 0,04 & 1,08 \\
\hline \multicolumn{8}{|l|}{ daidzina } \\
\hline BRS155 & 16,69 & 21,23 & 15,63 & 14,08 & 4,54 & $-1,06$ & $-2,61$ \\
\hline BRS156 & 33,95 & 27,91 & 22,27 & 33,44 & $-6,04$ & $-11,68$ & $-0,51$ \\
\hline BRS183 & 30,67 & 32,83 & 32,18 & 32,67 & 2,16 & 1,51 & 2,00 \\
\hline BRS216 & 20,08 & 19,66 & 18,18 & 17,39 & $-0,42$ & $-1,90$ & $-2,69$ \\
\hline BRS231 & 13,27 & 13,76 & 13,73 & 33,77 & 0,49 & 0,46 & 20,50 \\
\hline BRS233 & 17,5 & 11,78 & 22,9 & 21,13 & $-5,72$ & 5,40 & 3,63 \\
\hline BRM & 31,92 & 33,07 & 37,36 & 34,26 & 1,15 & 5,44 & 2,34 \\
\hline média & 23,44 & 22,89 & 23,18 & 26,68 & $-0,55$ & $-0,26$ & 3,24 \\
\hline \multirow[t]{2}{*}{ desvio padrão } & 8,47 & 8,64 & 8,70 & 8,81 & 3,96 & 5,80 & 8,00 \\
\hline & & & & t6 & $-0,34$ & $-0,11$ & 0,99 \\
\hline \multicolumn{8}{|l|}{ glicitina } \\
\hline BRS155 & 7,92 & 11,73 & 6,69 & 5,46 & 3,81 & $-1,23$ & $-2,46$ \\
\hline BRS156 & 18,87 & 15,12 & 10,91 & 17,1 & $-3,75$ & $-7,96$ & $-1,77$ \\
\hline BRS183 & 11,04 & 10,46 & 13,18 & 11,1 & $-0,58$ & 2,14 & 0,06 \\
\hline BRS216 & 11,8 & 12,53 & 11,6 & 10,7 & 0,73 & $-0,20$ & $-1,10$ \\
\hline BRS231 & 9,06 & 9,16 & 8,07 & 23,77 & 0,10 & $-0,99$ & 14,71 \\
\hline BRS233 & 15,97 & 8,66 & 19,17 & 18,78 & $-7,31$ & 3,20 & 2,81 \\
\hline BRM & 4,51 & 6,5 & 8,94 & 7,53 & 1,99 & 4,43 & 3,02 \\
\hline média & 11,31 & 10,59 & 11,22 & 13,49 & $-0,72$ & $-0,09$ & 2,18 \\
\hline \multirow[t]{2}{*}{ desvio padrão } & 4,86 & 2,83 & 4,14 & 6,59 & 3,73 & 4,09 & 5,92 \\
\hline & & & & t6 & $-0,47$ & $-0,05$ & 0,90 \\
\hline \multicolumn{8}{|l|}{ genistina } \\
\hline BRS155 & 28,42 & 27,88 & 29,8 & 25,42 & $-0,54$ & 1,38 & $-3,00$ \\
\hline BRS156 & 33,01 & 31,67 & 25,86 & 38,94 & $-1,34$ & $-7,15$ & 5,93 \\
\hline BRS183 & 60,9 & 66,11 & 60,7 & 65,12 & 5,21 & $-0,20$ & 4,22 \\
\hline BRS216 & 23,76 & 25,66 & 23,97 & 23,35 & 1,90 & 0,21 & $-0,41$ \\
\hline BRS231 & 16,75 & 15,67 & 17,19 & 48,28 & $-1,08$ & 0,44 & 31,53 \\
\hline BRS233 & 30,91 & 36,81 & 34,6 & 32,88 & 5,90 & 3,69 & 1,97 \\
\hline
\end{tabular}




\begin{tabular}{|c|c|c|c|c|c|c|c|}
\hline BRM & 55,14 & 64,18 & 65,6 & 60,32 & 9,04 & 10,46 & 5,18 \\
\hline média & 35,56 & 38,28 & 36,82 & 42,04 & 2,73 & 1,26 & 6,49 \\
\hline \multirow[t]{2}{*}{ desvio padrão } & 16,32 & 19,45 & 18,81 & 16,46 & 4,05 & 5,25 & 11,49 \\
\hline & & & & t6 & 1,65 & 0,59 & 1,38 \\
\hline \multicolumn{8}{|l|}{$\begin{array}{l}\text { malonil- } \\
\text { daidznia }\end{array}$} \\
\hline BRS155 & 30,97 & 35,3 & 28,71 & 23,99 & 4,33 & $-2,26$ & $-6,98$ \\
\hline BRS156 & 54,9 & 46,25 & 36,09 & 52,85 & $-8,65$ & $-18,81$ & $-2,05$ \\
\hline BRS183 & 57,15 & 58,54 & 57,74 & 58,4 & 1,39 & 0,59 & 1,25 \\
\hline BRS216 & 34,5 & 36,22 & 32,91 & 31,07 & 1,72 & $-1,59$ & $-3,43$ \\
\hline BRS231 & 22,64 & 21,79 & 22,47 & 56,55 & $-0,85$ & $-0,17$ & 33,91 \\
\hline BRS233 & 31,76 & 29,49 & 37,88 & 34,37 & $-2,27$ & 6,12 & 2,61 \\
\hline BRM & 67,01 & 65,79 & 74,02 & 69,16 & $-1,22$ & 7,01 & 2,15 \\
\hline média & 42,70 & 41,91 & 41,40 & 46,63 & $-0,79$ & $-1,30$ & 3,92 \\
\hline \multirow[t]{2}{*}{ desvio padrão } & 16,71 & 15,82 & 18,09 & 16,77 & 4,11 & 8,53 & 13,66 \\
\hline & & & & t6 & $-0,47$ & $-0,37$ & 0,70 \\
\hline \multicolumn{8}{|l|}{$\begin{array}{l}\text { malonil- } \\
\text { glicitina }\end{array}$} \\
\hline BRS155 & 12,73 & 16,83 & 10,35 & 8,18 & 4,10 & $-2,38$ & $-4,55$ \\
\hline BRS156 & 26,85 & 21,05 & 14,89 & 22,71 & $-5,80$ & $-11,96$ & $-4,14$ \\
\hline BRS183 & 15,43 & 15,11 & 17,08 & 14,71 & $-0,32$ & 1,65 & $-0,72$ \\
\hline BRS216 & 16,99 & 18,05 & 16,14 & 14,62 & 1,06 & $-0,85$ & $-2,37$ \\
\hline BRS231 & 13,58 & 12,84 & 11,91 & 32,2 & $-0,74$ & $-1,67$ & 18,62 \\
\hline BRS233 & 20,9 & 16,96 & 24,6 & 23,21 & $-3,94$ & 3,70 & 2,31 \\
\hline BRM & 13,73 & 11,55 & 14,44 & 13,85 & $-2,18$ & 0,71 & 0,12 \\
\hline média & 17,17 & 16,06 & 15,63 & 18,50 & $-1,12$ & $-1,54$ & 1,32 \\
\hline \multirow[t]{2}{*}{ desvio padrão } & 5,08 & 3,21 & 4,59 & 8,01 & 3,26 & 5,04 & 8,00 \\
\hline & & & & t6 & $-0,84$ & $-0,75$ & 0,41 \\
\hline \multicolumn{8}{|l|}{$\begin{array}{l}\text { malonil- } \\
\text { genistina }\end{array}$} \\
\hline BRS155 & 43,17 & 40,62 & 45,63 & 36,58 & $-2,55$ & 2,46 & $-6,59$ \\
\hline BRS156 & 52,98 & 48,8 & 39,85 & 59,61 & $-4,18$ & $-13,13$ & 6,63 \\
\hline BRS183 & 101,06 & 108,29 & 97,6 & 103,17 & 7,23 & $-3,46$ & 2,11 \\
\hline BRS216 & 40,12 & 43,53 & 41,38 & 39,52 & 3,41 & 1,26 & $-0,60$ \\
\hline BRS231 & 23,67 & 22,89 & 26,7 & 66,23 & $-0,78$ & 3,03 & 42,56 \\
\hline BRS233 & 46,06 & 55,41 & 55,45 & 51,79 & 9,35 & 9,39 & 5,73 \\
\hline BRM & 98,93 & 110,77 & 111,58 & 107,11 & 11,84 & 12,65 & 8,18 \\
\hline média & 58,00 & 61,47 & 59,74 & 66,29 & 3,47 & 1,74 & 8,29 \\
\hline \multirow[t]{2}{*}{ desvio padrão } & 30,04 & 34,31 & 32,05 & 28,52 & 6,21 & 8,45 & 15,93 \\
\hline & & & & t6 & 1,37 & 0,51 & 1,27 \\
\hline \multicolumn{8}{|l|}{ daidzeína } \\
\hline BRS155 & 2,3 & 1,31 & 2,24 & 2,29 & $-0,99$ & $-0,06$ & $-0,01$ \\
\hline BRS156 & 1,62 & 1,52 & 1,82 & 2,36 & $-0,10$ & 0,20 & 0,74 \\
\hline BRS183 & 2,11 & 5,85 & 2,49 & 2,6 & 3,74 & 0,38 & 0,49 \\
\hline BRS216 & 1,15 & 1,93 & 1,65 & 2,04 & 0,78 & 0,50 & 0,89 \\
\hline BRS231 & 1,52 & 0,95 & 1,52 & 1,6 & $-0,57$ & 0,00 & 0,08 \\
\hline BRS233 & 1,68 & 1,79 & 3,44 & 3,31 & 0,11 & 1,76 & 1,63 \\
\hline BRM & 2,53 & 3,29 & 2,45 & 4,63 & 0,76 & $-0,08$ & 2,10 \\
\hline média & 1,84 & 2,38 & 2,23 & 2,69 & 0,53 & 0,39 & 0,85 \\
\hline
\end{tabular}




\begin{tabular}{|c|c|c|c|c|c|c|c|}
\hline \multirow[t]{2}{*}{ desvio padrão } & 0,49 & 1,70 & 0,66 & 1,00 & 1,56 & 0,65 & 0,78 \\
\hline & & & & t6 & 0,84 & 1,46 & 2,66 \\
\hline \multicolumn{8}{|l|}{ gliciteína } \\
\hline BRS155 & 0 & 0,33 & 0 & 2,04 & 0,33 & 0,00 & 2,04 \\
\hline BRS156 & 1,99 & 0,43 & 0,67 & 2,56 & $-1,56$ & $-1,32$ & 0,57 \\
\hline BRS183 & 0,87 & 0 & 0,77 & 1,92 & $-0,87$ & $-0,10$ & 1,05 \\
\hline BRS216 & 0,58 & 0 & 0,61 & 0,7 & $-0,58$ & 0,03 & 0,12 \\
\hline BRS231 & 0,61 & 0,67 & 0 & 0,85 & 0,06 & $-0,61$ & 0,24 \\
\hline BRS233 & 0,68 & 0,14 & 1,91 & 0 & $-0,54$ & 1,23 & $-0,68$ \\
\hline BRM & 0 & 0 & 0,5 & 0,13 & 0,00 & 0,50 & 0,13 \\
\hline média & 0,68 & 0,22 & 0,64 & 1,17 & $-0,45$ & $-0,04$ & 0,50 \\
\hline \multirow[t]{2}{*}{ desvio padrão } & 0,67 & 0,26 & 0,64 & 1,00 & 0,65 & 0,80 & 0,86 \\
\hline & & & & t6 & $-1,71$ & $-0,12$ & 1,41 \\
\hline \multicolumn{8}{|l|}{ genisteína } \\
\hline BRS155 & 1,68 & 1,61 & 1,76 & 1,58 & $-0,07$ & 0,08 & $-0,10$ \\
\hline BRS156 & 1,24 & 1,19 & 1,14 & 1,58 & $-0,05$ & $-0,10$ & 0,34 \\
\hline BRS183 & 3,77 & 4,04 & 3,73 & 4,09 & 0,27 & $-0,04$ & 0,32 \\
\hline BRS216 & 1,26 & 1,29 & 1,41 & 1,23 & 0,03 & 0,15 & $-0,03$ \\
\hline BRS231 & 0,78 & 0,81 & 0,92 & 1,94 & 0,03 & 0,14 & 1,16 \\
\hline BRS233 & 1,68 & 1,84 & 1,61 & 1,86 & 0,16 & $-0,07$ & 0,18 \\
\hline BRM & 1,98 & 2,14 & 2,44 & 2,32 & 0,16 & 0,46 & 0,34 \\
\hline média & 1,77 & 1,85 & 1,86 & 2,09 & 0,08 & 0,09 & 0,32 \\
\hline \multirow[t]{2}{*}{ desvio padrão } & 0,96 & 1,06 & 0,96 & 0,95 & 0,12 & 0,19 & 0,41 \\
\hline & & & & t6 & 1,49 & 1,13 & 1,87 \\
\hline
\end{tabular}

* Os valores não estão expressos massa equivalente de agliconas. 


\section{REFERÊNCIAS}

ADLERCREUTZ, H.; MAZUR, W. Phyto-estrogens and Western diseases. Ann. Med., v. 29, p. 95-120, 1997.

AGUIAR, C.L. Transformacões físicas e biológicas de isoflavonas conjugadas de soja (Glycine max L.) e o efeito na atividade biológica in vitro. Tese (Doutorado) - Faculdade de Engenharia de Alimentos da Universidade Estadual de Campinas, Campinas, SP, 2004.

AMIC, D; DAVIDOVIC-AMIC, D; BESLO, D; TRINAJSTIC, N. Structure-radical scavenging activity relationships of flavonoids. Croatica Chemica Acta, v. 76 (1), p. 55-61, 2003.

ANDERSON, J.W.; JOHNSTONE, B.M. ;COOK-NEWELL, M.L. Meta-analysis of the effects of soy protein intake on serum lipids. New Eng. J. Med., v. 33, p. 276, 1995.

ÀVILA, M.R.; BRACCINI, A.L.; SCAPIN, C.A; MANDARINO, J.M.G.; ALBRECHT, L.P.; VIDIGAL FILHO, P. S. Componentes do Rendimento, Teores de Isoflavonas, Proteínas, Óleo e Qualidade de Sementes de Soja. Revista Brasileira de Sementes, v 29, n. 3, p. 111-127, 2007.

ATTA, S., AHMAD, T., ZEB, A., NAGRA, S. A. The ESR method to detect the irradiated fish and beef bones. J. Chem. Soc. of Pakistan, v. 30, n. 5, p. 708$711,2008$.

ATMACA, A.; KLEEREKOPER, M.; BAYRAKTAR, M.; KUCUK, O. Soy isoflavones in the management of postmenopausal osteoporosis. MenopauseThe Journal of the North American Menopause Society, v. 5, n. 4, p. 748-757, 2008.

BARNES, S. Evolution of the health benefits of soy isoflavones. Proc. Soc. Exp. Biol. Med., v. 217, p. 386-392, 1998.

BARNES S.; KIRK, M.; COWARD, L.. Isoflavones and their conjugates in soy foods: extraction conditions and analysis of HPLC - mass spectrometry. J. Agric. Food Chem., v. 42, p. 2466-2474, 1994.

BARROS, A.C. Identificação por Ressonância Paramagnética Eletrônica, teste do cometa de DNA e teste de germinação de trigo irradiado por raios gama. Dissertação (Mestrado) - Centro de Energia Nuclear para a Agricultura, Universidade de São Paulo, Piracicaba-SP, 2002.

BENNETT, J.E., INGRAM, D.J.E., TAPLEY, J.G. Paramagnetic resonance from broken carbon bonds. J. Chem. Phys., v. 23, p. 215, 1955. 
BORDIGNON, J.R.; TSUSHIDA, T.; YAMAKI, K.; NEPOMUCENO, A.L.; FARIAS, J.R.; NEUMAIER, N. Effect of water deficiency in the isoflavone contents in Brazilian soybean cultivars. In: Proceedings of the Third International Soybean Processing and Utilization Conference, Tsukuba, October 15-20, 2000.

BRASIL. Ministério da Saúde. Resolução - RDC n. 21 de Janeiro de 2001. Agência Nacional de Vigilância Sanitária. República Federativa do Brasil Diário Oficial [da], Brasília. DF 29 de Janeiro de 2001. n. 20.

BYUN, M.W.; KWON, J.H.; MORI, T. Improvement of physical properties of soybeans by gamma irradiation. Radiat. Phys. Chem., v.42, n. 1-3, p.313-317, 1993.

BYUN, M.W.; KANG, I.J.; KWON, J.H.; HAYASHI, Y. e MORI, T. Physicochemical properties of soybean oil extracted from gamma-irradiated soybeans. Radiat. Phys. Chem. v. 47, n.. 2, p. 301-304, 1996.

BYUN, M.W.; SON, J.H.; YOOK, H.S.; JO, C.; KIM, D.H. Effect of gamma irradiation on the physiological activity of Korean soybean fermented foods, Chungkookjang and Doenjang. Radiat. Phys. Chem., v. 64, p. 245-248, 2002.

CARRÃO-PANIZZI, M. C. e KITAMURA, K.. Isoflavone content in Brazilian soybean cultivars. Breed. Sci., v.45, p. 295-300, 1995.

CARRÃO-PANIZZI, M. C. Avaliação de Cultivares de Soja quanto aos teores de isoflavonóides. Pesq. Agrop. Brasileira, v.31, n.10, p.691-698, 1996.

CARRÃO-PANIZZI, M.C; KITAMURA, K.; BELÉIA, A.P. e OLIVEIRA, M.C.N. Influence of growth locations on isoflavonee contents in Brazilian soybean cultivars. Breed. Sci., v.48, p. 409-413, 1998.

CARRÃO-PANIZZI, M.C. Activity of beta-glucosidase and levels of isoflavone glucosides in soybean cultivars affected by the environment. Pesq. Agrop. Brasileira, v. 35, n.5, 2000.

CARRÃO-PANIZZI, M. C.; ALMEIDA, L.A; KIIHL, R.A.S.; MIRANDA, L.C; KIKUCHI, A.; MANDARINO, J.M.G.; BORDIGNON, J.R.; SHIGEFUMI. Breeding efforts for nutritional and food processing qualitity of soybean at EMBRAPA, Brazil. Proceedings of the Third International Soybean Processing and Utilization Conference, Tsukuba, October 15-20, 2000.

CODEX ALIMENTARIUS COMMISSION. Codex General Standard for Irradiated Foods. CODEX STAN 106-1983, Rev. 1-2003.

COSTA NETO, P.L. Estatística. 2 ed. São Paulo: Edgard Blücher, 2002.

COWARD, L.; BARNES, N.C.; SETCHELE, K.D.R. e BARNES, S. Genistein, daidzein and their $\beta$-glycoside conjugates: antitumor isoflavones in soybean foods 
from American and Asian diets. J. Agric. Food. Chem., v. 41, p. 1961-1967, 1993

DAY, R.; KUPPER, M.B.; MOG, S.; McCART, E.; PRASANNA, P.G.S.; DAVIS, T.; LANDAUGER, M. Genistein Protects Against Biomarkers of Delayed Lung Sequels in Mice Surviving High-Dose Total Body Irradiation. J. Radiat. Res., v. 49, n. 4, p. 361-372, 2008.

DESROSIERS M.F. e SIMIC, M.G. Postirradiation dosimetry of meat by electron paramagnetic resonance spectroscopy. J. Agric. Food Chem., v. 36, p. 601-603, 1988.

DIEHL, J.F. Safety of Irradiated Foods. 2. ed. Karlshure: Marcel Dekker, Inc., 1995.

DIEHL, J.F. Food Irradiation - past, present and future. Radiat. Phys. Chem., v. 63, p. 211-215, 2002.

EMPRESA BRASILEIRA DE PESQUISA AGROPECUÁRIA - Embrapa Soja. http://www.cnpso.embrapa.br/index.php?op_page=22\&cod_pai=16, accesso em 23 março 2009.

EMPRESA BRASILEIRA DE PESQUISA AGROPECUÁRIA - Embrapa Soja, Tecnologias de produção de soja - região central do Brasil. Embrapa Soja, Londrina, 2003.

European Norms - 1787. Foodstuffs Detection of Irradiated Food Containing Cellulose by ESR Spectroscopy; European Committee of Standardization: Brussels, Belgium, 2001.

ENGIN, B., DEMIRTAS, H.; EKEN, M. Temperature effects on egg shells investigated by XRD, IR and ESR techniques. Radiat. Phys. Chem., v. 75, p. 268-277, 2006.

GENOVESE, M.I. e LAJOLO, F.M. Determinação de Isoflavonas em derivados de soja. J. Ciênc. Tecnol. Aliment., Campinas, v. 21, n.1, p. 86-93, 2001.

GENOVESE, M.I. e LAJOLO, F.M. Isoflavones in soy-based foods consumed in Brazil: levels, distribution, and estimated intake. J. Agric. Food Chem., v. 50, p. 5987-5993, 2002.

GENOVESE, M.I, HASSIMOTO, N.M.A and LAJOLO, F.M. Isoflavone, Profile and Antioxidant Activity of Brazilian Soybean Varieties. Food Sci.Tech. Int., v. 11, n.3, p. 205-211, 2005.

GLIDEWELL, S.M.; DEIGHTON, N.; GOODMAN, B.A. e HILLMAN, J.A. Detection of Irradiated Food: A Review. J. Sci. Food Agric., v. 61, p. 281-300, 1993. 
GONG, Y., XIAO-OU, S., HONGLAN, L. et al. Prospective cohort study of soy food intake and colorectal cancer risk in women. Am. J. Clin. Nutr,, v. 89, p. 577583, 2009.

GOODMAN B.A; MCPHAIL, D.B.; DUTHIE, D.M.L. Electron spin resonance of some irradiated foodstuffs. J. Sci. Food Agric., v. 47, p. 101-11, 1989.

HILLMAN, G.C., ROBINS, G.V., ODUWOLE, D., SALES, K.D., MCNEIL, D.A.C. Determination of thermal histories of archaeological cereal grains with electron spin resonance spectroscopy. Science, v. 222, p. 1235-1236, 1983

HUANG, A.S.; HSIEH, O.A.L. e CHANG, S.S. Characterization of the nonvolatile minor constituents responsible for the objetionable taste of defatted soybean flour. J. Food.Sci., v. 47, p. 19, 1981.

INTERNATIONAL CONSULTATIVE GROUP ON FOOD IRRADIATION. Training Manual on Operation of Food Irradiations Facilities. Document 14. Vienna, 1992.

IAEA - INTERNATIONAL ATOMIC ENERGY AGENCY. Use of irradiation to Ensure the Hygienic quality of fresh, pre-cut fruits and vegetables and other minimally processed food of plant origin. Vienna IAEA-TECDOC-1530, December, 2006.

IKEYA, M.; BAFFA, F.O. e MASCARENHAS, S. Quality Assessment of Coffee Beans with ESR and Gamma-ray Irradiation. Appl. Radiat. Isot., v. 40, n. 10-12, p. 1219-1222, 1989.

IKEYA, M.; MIKI, T. Electron spin resonance dating of animal and human bones. Science, v. 207, p.977, 1980.

IKEYA, M. New Applications of Electron Spin Resonance (Dating, Dosimetry and Microscopy) $1^{\text {st }}$ Ed., World Scientific, 1993.

INGRAM, D.J.E., TAPLEY, J.G., JACKSON, R., BOND, R.L., MURNAGHAN, A.R. Paramagnetic resonance in carbonaceous solids. Nature, v. 174, p. 797-798, 1954.

KAGAWA, A. (ed.) Standard table of food composition in Japan. Tokyo: University of Nutrition for women, p. 104-105, 1995.

KAMAT, A. Microbiological aspect of radiation processing of foods. J. Food Sci. Technol.-Mysore, v. 42, n. 5, p. 371-383, 2005.

KASUGA, A.; OGIWARA, E.; AOYAGI, Y.; KIMURA, H. Changes in isoflavone content of soybeans during heating process. J. Japanese Soc. Food Sci. Technol., v. 53, n. 7., p. 365-372, 2006. 
Kausar, T.; Kwon, J. H. ESR spectroscopy for identification of gamma-irradiated teas. Ind. J. Plant Sci., v. 3, p. 317-321, 2004.

KIM, J.H, SHIN, M.H, HWANG, Y.J, et al. Role of gamma irradiation on the natural antioxidants in cumin seeds. Radiat. Phys. Chem., v. 78, n. 2, p. 153157, 2009.

KITAMURA, K; IGITA, K; KIKUCHI, A.; KUDOU, S. e OKUBO, K. Low isoflavone content in early maturing cultivars, so called summer-type soybeans (Glycine max (L) Merrill). Japan J. Breed., v. 41, p. 651-654, 1991.

KUDOU,S.; FLEURY, Y.; WELTI, D.; MAGNOLATO, D.; UCHIDA,T.; KITAMURA, $\mathrm{K}$. e OKUBO, K. Malonyl isoflavone glucosides in soybean seeds (Glycine max merril). Agric. Biol. Chem., v. 55, p. 2227-2233, 1991.

KWON, J. H.; JEONG, J. Y.; LEE, E. Y.; JO, D.; NOH, J. E.; LEE, J. E. Multiple detection to identify irradiated brown rice of different origins. Food Sci. Biotechnol., v. 11, 215-219, 2002.

LEE, J.; KAUSAR, T.; KIM, B.K.; KWON, JH. Detection of y-Irradiated Sesame Seeds before and after Roasting by Analyzing Photostimulated Luminescence, Thermoluminescence, and Electron Spin Resonance. J. Agric. Food Chem, v. 56, p. 7184-7188, 2008.

LEE, E.J.; VOLKOV, V.I.; LEE, C.H. Electron Spin Resonance Studies of Free Radicals in Y-irradiated soybean paste. J. Agric. Food Chem., v. 49, p. 34573462, 2001.

LEE, E.J.; VOLKOV, V.I.; LEE, C.H. Detection of free radicals in gammairradiated soybean paste and model system by electron spin resonance spectroscopy. Radiat. Phys. Chem., v. 64, p. 61-66, 2002.

LEVEQUE, P. P.GODECHAL, Q., GALLEZ, B. EPR Spectroscopy and Imaging of Free Radicals in Food. Israel Journal of Chemistry, v. 48, n. 1, p. 19-26, 2008.

LIU, K. Soybeans: Chemistry, Technology, and Utilization. Chapman \& Hall IT Publishing, 1997.

MASCARENHAS, S.; BAFFA, O.F.; IKEYA, M. ESR dating of human bones from Brazilian Shell mounts (sambaquis). Am. Phys. Anthropol, v. 59, p. 413-418, 1982.

MASTRO, N. L. d. Development of Food Irradiation in Brazil. Progress in Nuclear Energy, v. 35, n.3-4, p. 229-248, 1999.

MATSUURA, M.; OBATA, A.; FUKUSHIMA, D. Objectionable flavor of soymilk developed during the soaking of soybeans and its control. Jounal of Food Science, v. 54, n.3, p.602-605, 1989. 
MESSINA, M.J. Soyfoods: Their role in disease prevention and treatment. Cap. 10 apud Liu, 1997; p.442-448, 1997.

MESSINA, M.J e WOOD, C.E. Soy isoflavones, estrogen therapy, and breast cancer risk: analysis and commentary. Nutrition Journal, v. 7, n. 17, 2008.

MESSINA, M.J. Legumes and soybeans: overview of their nutritional profiles and health effects. Am. J. Clin. Nutr., v. 70, p. 439-450, 1999

MIURA, Y. Oxidative Stress, Radiation-Adaptive Responses and Aging. J. Radiat. Res., v. 45, p. 357-372, 2004.

MOUSSAID M, LACROIX M, NKETSIA-TABIRI J, BOUBEKRI C. Phenolic compounds and the colour of oranges subjected to a combination treatment of waxing and irradiation. Radiat. Phys. Chem., v. 57, n. 3-6, p. 273-275, 2000.

OKUBO, K.; IJIMA, M.; KOBAYASHI, Y.; YOSHIKOSHI, M.; UCHIDA, T. e KUDOU, S. Components responsible for the undesirable taste of soybean seeds. Biosci. Biotechnol. Biochem., v. 56, p. 99-103, 1992.

OLIVEIRA, M.R.R.; MASTRO, N.L. d. Electron Paramagnetic Resonance study of some varieties of gamma-irradiated soybean. Radiat. Phys. Chem., v. 76, n. 8-9, p. 1459-1462, 2007.

OLIVEIRA, M.R.R.; MASTRO, N.L.d. 2004. Congreso Internacional Conjunto Cancún 2004 LAS/ANS-SNM-SMSR, 11-14 JUL, Cancun, Q.R., México, 2004.

OLSON, D. G. Irradiation processing In: HAYES, D. J. et al. Food Irradiation: A Sourcebook. Ames, IA: lowa State Univ. Press, 1995, p. 3-25.

OU, B.; HUANG, D.; HAMPSCH-WODRILL, M.; FLANAGAN, J.A.; DEEMER, E.K. Analysis of antioxidant activities of common vegetables employing oxygen radical absorbance capacity (ORAC) and ferric reducing antioxidant power (FRAP) assays: a comparative study. J. Agric. Food Chem., v. 50, p. 3122-3128, 2002.

OUFEDJIKH H, MAHROUZ M, AMIOT MJ, LACROIX M. Effect of gammairradiation on phenolic compounds and phenylalanine ammonia-lyase activity during storage in relation to peel injury from peel of citrus clementina Hort. ex. Tanaka. J. Agric. Food Chem., v. 48, n. 2, p. 559-565, 2000.

PARISH, R.V. NMR, NQR, EPR, and Mössbauer Spectroscopy in Organic Chemisty. London, Ellis Horwood Limited, 1990.

PARK, Y.K.; AGUIAR, C.L.; ALENCAR, S.M. et al. Survey of isoflavone contents in Brazilian soybean. Ciencia e Tecnologia Alimentária, v., n. 3, p. 156-160, 2001. 
POLAT, M.; KORKMAZ, M. Kinectics of the $\mathrm{Mn}^{2+}$ ion free radical observed in gamma-irradiated soybean (Glycine max L.). Food Research International, v. 36, n.9-10, p. 1073-1080, 2003.

PRASUNA, C.P.L.; CHAKRADHAR, R.P.S.; RAO, J.L.; GOPAL, N.O. EPR as an analytical tool in assessing the mineral nutrients and irradiated food productsvegetables. Spectrochimica Acta Part - Molecular and Biomolecular Spectroscopy, v. 71, n. 3, p. 809-813, 2008.

RAFFI, J.J e AGNEL, J.P. Electron spin resonance of crustacean as an example of identification of ionized food. Sci des Aliments, v. 10, p. 387-390, 1990.

RAFFI, J.; YORDANOV, N. D.; CHABANE, S.; DOUIFI, L.; GANCHEVA, V.; IVANOVA, S. Identification of irradiation treatment of aromatic herbs, spices and fruits by electron paramagnetic resonance and thermoluminescence. Spectrochim. Acta, Part A, v. 56, p. 409-416, 2000.

ROBINS, G.V., SEELEY, N.J., MCNEIL, D.A.C., SYMONS, M.R.C. Identification of ancient heat treatment in flint artifacts by ESR spectroscopy. Nature, v. 276, p. 703, 1978.

ROBINS, G.V. The study of heated and charred archaeological materials with electron spin resonance spectroscopy. J. Anal. Appl. Pyrol. v. 6, p. 31-43, 1984.

SANYAL, B., SAJILATA, M. G., CHATTERJEE, S., et al. Identification of irradiated cashew nut by electron paramagnetic resonance spectroscopy. J. Agric. Food Chem., v.56, n.19, p. 8987-8991, 2008.

SALES, K.D., ODUWOLE, A.D., ROBINS, G.V., OLSEN, S. The radiation and thermal dependence of ESR signals in ancient and modern bones. Nucl. Tracks, v. 10, 845-851, 1985.

SMITH, GJ, MARKHAM, KR. The dissipation of excitation energy in ethoxyflavones by internal conversion. J. Photochem. Photobiol..A-Chem., v. 99, n. 2-3, p. 97-101, 1996.

SONG, W.O.; CHUN, O.K.; HWANG, I.; SHIN, H. S.; KIM, BONG-GWAN; KIM, K.S.; LEE, SANG-YUN; SHIN, D.; LEE, S.G. Soy isoflavones as safe functional ingredients. J. Medicinal Food, v. 10, n. 4, p. 571-580, 2007.

SPIEGEL, M.R. Estatística. 3 ed. São Paulo, McGraw-Hill, 1993.

STASKO, A., BREZOVA, V., MAZUR, M., CERTIK, M., KALINAK, M., GESCHEIDT, G. A comparative study on the antioxidant properties of Slovakian and Austrian wines. LWT-Food Sci. Technol. v. 41, n. 10, p. 2126-2135, 2008.

SZÖCS, F. Free radicals in wheat seeds studied by electron spin resonance. Food Chemistry and Toxicology, v. 67, n. 6, p. 2079-2082, 2002. 
SWALLOW, A.J. Can we tell if our food has been irradiated? Chem. Br., v. 24, p. 102-105, 1989.

TOLEDO, T.C.F. Avaliação dos efeitos da radiação ionizante de 60 Co em propriedades físicas, químicas e nutricionais de dois diferentes cultivares de grãos de soja (Glycine max. L). Dissertação (Mestrado). Escola Superior de Agricultura “Luiz de Queiroz”, Universidade de São Paulo, Piracicaba-SP, 2006.

TODORIKI, S.; KIKUCHI, O.K.; NAKAOKA, M.; MIIKE, M.; HAYASHI, T. Soft electron (low energy electron) processing of foods for microbial control. Radiat. Phys. Chem., v. 63, p. 349-351, 2002.

TOLEDO, T.C.F.; CANNIATTI-BRAZACA, S.G.; ARTHUR, V.; PIEDADE, S.M.S. Effects of gamma radiation on total phenolics, trypsin and tannin inhibitors in soybean grains. Radiat. Phys. Chem., v. 76, p. 1653-1656, 2007.

VALENZUELA, A; SANHUEZA, J; ALONSO, P.; CORBARI, A.; NIETO, S. Inhibitory action of conventional food-grade natural antioxidants and of natural antioxidants of new development on the thermal-induced oxidation of cholesterol. International J. Food Sciences and Nutrition, v. 55. n.2, p. 155-162, 2004.

VARIYAR, P.S.; LIMAYE, A; SHARMA, A. A Radiation-Induced Enhancement of Antioxidant Contents of Soybean (Glycine max. Merryl). J. Agric Food Chem., v. 52, p. 3385-3388, 2004.

VASCONCELOS, Y. Lavoura mais produtiva. Ciência e Tecnologia no Brasil Pesquisa FAPESP, n.150, p.90-91, 2008.

VISKUPICVA, J.; ONDREJOVIC, M.; STURDIK, E. Bioavailability and metabolism of flavonoids. J. Food Nutrition Res., v. 47, n. 4, p. 151-162, 2008.

WANG, H.J.; MURPHY, P.A. Isoflavone Content in Commercial Soybean Foods. J. Agric. Food. Chem., v. 42, p. 1666-1673, 1994.

WATANABE, S.; UESUGI, S., KIKUCHI, Y. Isoflavones for prevention of cancer, cardiovascular diseases, gynecological problems and possible immune potentiation. Biomedicine \& Pharmacotherapy, v. 56, n. 6, p. 302-312, 2002.

WHO. Wholesomeness of food irradiated with doses above 10 kGy: Report of a Joint FAO/IAEA/WHO Study Group. Geneva, WHO, (Technical Report Series, 890), 1999.

YAMAOKI, R., KIMURA, S., OHTA, M. Free radical kinetics on irradiated fennel. Radiat. Phys. Chem., v. 77, n. 9, p. 1057-1061, 2008.

YANG, G.C.; MOSSOBA, M.M.; MERIN, U. e ROSENTHAL, I. An EPR Study of Free Radicals Generated by Gamma-Radiation of Dried Spices and SprayDried Fruit Powders, Journal of Food Quality, v. 10, p. 287- 294, 1987. 